\title{
STATEN OG
}

\section{GENNEMSNITSPROFITRATEN}

\author{
Ole Fogh Kirkeby
}

\section{Forord}

I den følgende tekst skal statens funktioner i det kapitalistiske samfund bestemmes ud fra niveauet-for-kapitalen-i-dens-realitet, altså ud fra konkurrencens begreb. Det betyder, at statens funktion overfor totalkapitalen - der jo kun har karakter af en abstrakt funktionssammenhæng - går igennem enkeltkapitalerne, og at statens mål og midler skal forstås i forhold til enkeltkapitalerne og disses organisering i sektorer og brancher.

Statens historiske funktion fra begyndelsen af det 19-nde århundrede har været at opretholde den privatretslige basis, der udgør kapitalismens fundament, når denne basis blev truet brugte staten magt og klassemodsætningerne var udtalt på overfladen. Men som det kapialistiske samfund har udviklet sig har statens funktion fået en langt mere legitimerende og instrumentalistisk karakter, også selvom dens funktioner stadigvæk er de samme: opretholdelsen af de basale ejendomsforhold er kun mulig hvis kapitalvaloriseringen fungerer nogenlunde glat, dvs. hvis $\varnothing$ konomisk vækst kan stabilisere de modsætninger hvorover samfundet består.

I selve de objektive love hvorigennem kapitalrelationen reproduceres ligger der - på baggrund af det parlamentariske systems institutionelle og politiske rammer - en række fremtrædelsesformer, eller tankeformer af »objektiv karakter «, der følger af individernes praksis under kapitalismen og ifølge deres væsen bekræfter kapitalismen som et system hvori de forskellige gruppers materielle interesser tilgodeses effektivt, ja måske bedst. 
I slutningen af bd. III af Das Kapital og i slutningen af bd. III af Theorien über den Mehrwert findes der passager, hvori Marx under betegnelsen »revenukilde « søger at bestemme de former, hvorunder kapitalforholdet på det konkreteste plan af samfundsprocessen fremtræder for de implicerede, således, at der i formen for fremtrædelsen er indbygget en legitimation af kapitalens eksistens.

Kapital, arbejde og jordejendom fremtræder - siger Marx - som ligestillede indtægtskilder, der - trods stoflige forskelligheder - yder kvalitativt samme præstation ved totalproduktets skabelse. Arbejdet fremtræder altså ikke som kilden til al brugsværdi og værdi (jeg ser her bort fra »naturens« rolle ved skabelsen af brugsværdier) men også kapital og jord fremtræder som umiddelbart værdiskabende.

At kapitalen fremtræder således kan først forstås når vi har gennemtænkt konkurrencens former og rentekapitalen: for i konkurrencen, dvs. i den proces, hvori gennemsnitsprofitraten og produktionspriserne dannes, fremtræder forholdet mellem summen af enkeltkapitaler og totalmerværdien således, at hver enkelt kapital får profit proportionalt med sin totale størrelse, og ikke i forhold til den værdimasse, som det arbejde skaber der er underkastet denne kapital. Både konstant og variabel kapital fremtræder som lige »produktive« ved skabelsen af værdi.

Rentekapitalen er ifølge Marx det mest ekstreme eksempel på hvordan kapitalens fremtrædelsesformer kan skjule det forhold, at det er arbejdet alene, der er kilde til al værdi i kapitalismen. Rentekapitalen er kapitalens mest abstrakte form, abstrakt i betydningen, at ethvert spor af kapitalens oprindelse er blevet udslukt. Passiv kapitalbesiddelse er her blevet forvandlet til en konstitutionsret til en del af totalproduktet. Ikke alene synes rentefoden en »naturlig « del af omkostningsprisen, et vederlag til besidderen af produktionsfaktoren »penge« for hans risiko men rentekapitalen synes produktiv på linie med industrikapitalen, den opfattes som samfundsnødvendig i egenskab af integrerende del af produktionen.

Kapitalens (i form af produktionsmidler og penge), jordejendommens og arbejdskraftens frugter opfattes som »revenu«, som indtægt, og det er nu den borgerlige stats opgave at sikre eksistensen af disse indtægtskilder, at sikre indtægtens størrelse og kontinuitet. Om disse abstrakte funktioner kan revenukildeejerne forenes på trods af de helt fundamentale modsætninger mellem dem.

Det har været von Flatow/Huiskens' fortjeneste at gøre opmærksom på revenukilde-illusionernes - også kaldet »den trinitariske formel « - rolle ved etableringen af samfundet som et fungerende fællesskab og staten som et aktionsdygtigt instrument. De har præciseret, at statens aktionsgrundlag, basis for dens selvforståelse og for de mål og midler den kan betjene sig af, er de former for legitimation, der er indeholdt i kapitalens egne formbestemmelser. ${ }^{1}$

1. Sibylle von Flatow/Freerk Huiskens: Zum Problem der Ableitung des bürgerlichen Staates. Die Oberfläche der bürgerlichen Gesellschaft, der Staat und die allgemeinen Rahmenbedingungen der Produktion. Probleme des Klassenkampfs, nr. 7, Mai 1973. Dansk oversættelse: Kurasje nr. 9 og 10. 
Men på trods af deres fortjeneste kan von Flatow/Huiskens ikke besvare flere alvorlige problemer i forbindelse med bestemmelsen af statens rolle $\mathrm{i}$ kapitalismen: for den første kan den trinitariske formel ikke give det virkelige grundlag for den rationalitet indenfor hvilken staten handler, og for det andet er den trinitariske formel for abstrakt med henblik på de konkretere formbestemmelser, der kendetegner statens aktionsformer på niveauet for kapitalen-idens-realitet: her giver opspaltningen af kapitalen i industrikapital, handelskapital, pengekapital og rentekapital lejlighed til udkrystalliseringen af en række særinteresser, der kompletteret med dem, der udspringer af statens rolle på verdensmarkedet gør revenu-kildebegrebet til noget alt for abstrakt.

Men den trinitariske formel udgør trods alt kernen i statens legitimationsbasis, den udgør i vid udstrækning de briller hvorigennem staten fortolker samfundet og dermed sin egen aktivitet.

Det er da målet for denne artikel først at fremstille statens funktion i konkurrencen, altså dens rolle ved konstituteringen af udbuddet og efterspørgslen og dermed for dannelsen af gennemsnitsprofitraten på baggrund af en tre-sektor-model. Statens forbindelse med den økonomiske basis og dermed statsinterventionens objektive grundlag etableres gennem skabelsen af udbud og efterspørgsel på grundlag af konkurrencen mellem enkeltkapitalerne.

Efter rekonstruktion af dette objektive grundlag, dvs. efter fremstillingen af betingelserne for dannelsen af gennemsnitsprofitraten og produktionspriserne kan kapitalens konkretere forbestemmelser indenfor cirkulationssfæren fremstilles, her især med henblik på en klargørelse af kredittens funktion i en åben økonomi, altså sammenhængen mellem kredit, akkumulationsfond og gennemsnitsprofitrate.

Endelig kan på baggrund af denne viden statsinterventionens illusioner og rationelle kerne opspores, og her skelnes der mellem to former for statsintervention: den der fandt sted efter anden verdenskrig og som toppede ved krisen i 73-74 og den, der afløste denne traditionelle form for statsintervention, og som karakteriseres af kraftige standsninger i statens udbudefterspørgselsskabende funktioner: stop for byggeri, offentlige ansættelser, etc.

Afgørende er her hvilke totalforestillinger, der gør statens aktionsskifte muligt, dvs. hvilke fremtrædelsesformer for kaptialens formspecificeringer, der tvinger staten til at skifte midler i den $\varnothing$ konomiske politik.

Den metode jeg her benytter mig af er den Marx anvender i Das Kapital og i Theorien über den Mehrwert: det drejer sig om udviklingen af den objektive basis, altså om udviklingen af kapitalens begreb på alle niveauer, og derefter om bestemmelsen af de mål og midler som medlemmerne af det kapitalistiske samfund og dermed staten kan sætte sig gennem en rekonstruktion af deres erfaringsgrundlag. Dette foregår gennem en dialetisk bevægelse mellem empirisk systematisering af partiers, organisationers og videnskabsmænds illusioner og så kendskabet til en række objektive tankeformer, der kan deduceres ud af kapitalens fetichformer og som så kan tjene som forklaring på de faktiske illusioners nødvendighed. 
Illusionerne er ikke logisk nødvendige, men deres gennemslag som basale erfarings- og aktionsdogmer er afhængig af klassekampens konkrete udformning. En målbevidst artikulation af proletariatets klasseinteresser vil ikke gøre disse illusioner mulige som generelle tanke- og handlingskategorier. De hænger nøje sammen med arbejderbevægelsens revisionistiske praksis.

Årsagen til at den trinitariske formel er blevet den illusionsform, der kan forklare statens legitimationsbasis idag hører altså nøje sammen med udviklingen indenfor arbejderbevægelsens partier og organisationer, hvor et samspil mellem disse illusioner som objektive muligheder for erkendelsesog aktionsgrænser og så arbejderbevægelsens mål, midler og kamperfaringer er historiens drivkraft. I takt med at basis for deres opfyldelse er blevet skabt gennem en stigning i bruttonationalproduktet er arbejderens »materielle interesser blevet mindre og mindre systemkritiske, den revolutionære horisont er blevet begrænset til lønkampe uden videre perspektiv.

Statens rolle i sen-kapitalismen er at gøre den fortsatte pacifisering af arbejderklassen materielt mulig ved at sikre nationalkapitalen, men denne rolle artikuleres for staten i en række isolerede konflikter, hvor forholdet til verdensmarkedet spiller en afgørende rolle. Påvisningen af hvordan statens rolle skabes uden at totalkapitalen har status af en handlekraftig enhed, men netop skabes gennem statens holdning til kapitalformernes særinteresser og til forholdene omkring arbejdskraftens reproduktion og skabes på en sådan måde, at ikke alene adskillige kapitalgruppers, men også totalkapitalens valorisering bringes i vanskeligheder, er det opgaven for denne artikel at belyse.

Statens intervention, der sker af hensyn til bevarelsen af den økonomiske basis, må således ifølge sit væsen i netop den handling, hvormed den sikrer denne basis' eksistens, forøge de modsigelser som er indeholdt i den. Staten er som instans selv underkastet modsigelserne i kapitalens væsen.

Når denne artikel focuserer på kapitalens bevægelser og afgrænser statens handlingsunivers ud fra revenukildebevidstheden, så er det et perspektiv, der er nødvendiggjort af statens gennemført borgerlige karakter og parlamentarismens feticheringsgrundlag. Men det er ikke et programmatisk perspektiv for en analyse af kapitalismen ud fra det proletariske standpunkt i den forstand, at netop denne indfaldsvinkel skulle være den eksklusive og omfattende rigtige.

Når jeg i min analyse af konkurrencens begreb udelukkende focuserer på forholdet mellem kapitaler, så udelukker jeg naturligvis den dimension af konkurrencen, der bestemmes af arbejderklassens aktionshistorie: tekniske forandringer i produktionsprocessen er selvfølgelig ofte svar på arbejdskraftens aktivitet og ikke blot en kapitaliststrategi, hvis omfang og indhold udtømmende kan beskrives ud fra kampen mellem kapitaler om markedsandele.

Perspektivet i denne artikel er dog et nødvendigt gennemgangsled ved etableringen af arbejderklassens aktionshistorie, idet kapitalisternes handlinger 
overfor arbejderklassen i vidt omfang er bestemt af den herskende konkurrence mellem kapitaler: jo lavere markedsværdinivo indenfor en branche, jo større konkurrence mellem kapitalerne altså, desto voldsommere virkningerne har spontane reaktioner fra arbejderside i produktionsprocessen.

Mit ærinde med denne artikel er at skabe den platform, hvorudfra kapitalisternes reaktioner på arbejderklassens aktioner virkelig kan systematiseres og erkendes i deres indre nødvendighed. Men forståelsen er naturligvis kun komplet når arbejderklassens aktionshistorie bliver målet for brancheog totalanalysen fra marxistisk hold. Jeg håber at have bidraget lidt til den her fra mit særegne og absolut ikke fyldestgørende perspektiv: for formålet med at skrive kapitalens historie er naturligvis kun at skrive arbejderklassens negative historie, dvs. at blotlægge de objektive rammer for og påvise den entydige mulighed af den modmagt, hvis levende virkelighed det er arbejderklassens aktionshistories formål at afdække med henblik på direkte aktion.

\section{Del I}

\section{Kapitel 1}

\section{Indledning:}

Denne artikel er et forsøg på at fremstille en af de nødvendige årsager til inflationen i senkapitalismen.

Dens udgangspunkt er kapitalens lovmæssigheder på nivoet for kapitalen i dens realitet, altså på det nivo, hvor konkurrencen mellem kapitaler indenfor og mellem brancherne behandles, og den følger Marx'fremstilling af forholdene i bd. III af Das Kapital og i bd. II af Theorien über den Mehrwert.

Der kan næppe være tvivl om at udviklingen i priserne i senkapitalismen står i den grelleste kontrast til udviklingen i arbejdets produktivitet. Der er tale om en omtrentlig ensartet udvikling i indekset for produktivitet og i indekset for forbrugerpriserne hvad angår de førende kapitalistiske nationer. Der er ingen proportionalitet mellem udviklingen af arbejdets produktivitet og så prisudviklingen: priserne stiger derimod med stigende arbejdsproduktivitet, og det gælder især halv- eller helfabrikata. 
Ifølge PPII s. 148 er produktiviteten per beskæftiget steget med næsten 60\% fra 1960 til 1972. Fra 1965 til 1972 stiger indeksværdierne for industrivarer hovedsageligt af dansk oprindelse med $43 \% .^{1}$

Det har været en tendens i de moderne analyser af inflationen at begrunde denne i udvidelser af penge- og kreditmassen i forhold til produktmassen. Denne antagelse går tilbage til Ricardos »kvantitetsteori og har sine moderne varetagere i den såkaldte »Chicago-skole« med Milton Friedman som sin væsentligste repræsentant. ${ }^{2}$ Også på marxistisk grund har der hersket tvivl om inflationens årsager. Karakteristisk for den nyeste debat er Altvater, Hoffmann, Künzel og Semmler i deres forsøg på at opstille et alternativ til Hofmanns begreb »den sækulare inflation «. ${ }^{3}$

Men afgørende for alle disse indfaldsvinkler - hvad enten de foregår på den subjektive eller på den objektive værditeoris præmisser - er, at de ikke formår at stille og løse problemet om inflationen i hele dets systematiske konsekvens. En løsning kan nemlig her kun udvikles på baggrund af den teoretiske forståelse af betingelserne for identitet og variation mellem værdi og pris.

Dette problem bliver først eksistent på det nivoet af Marx' analyse, der kaldes »nivoet for kapitalen i dens realitet«, eller »nivoet for de mange enkeltkapitaler«: det drejer sig om at udvikle værditeorien således, at man v.hj. af den og v.hj. af begrebet for kapitalen kan gøre omfattende og systematisk rede for alle væsentlige afvigelser mellem værdi og pris og for afvigelsesformens konstitutionssammenhæng.

Den marxistiske indfaldsvinkel må afvise både løn-pris-spiral-begrebet såvel som den kvantitetsteoretiske tilnærmelse som værende adækvate angrebsvinkler til en bestemmelse af inflationen. ${ }^{4}$

Inflationen må bestemmes ud fra kapitalens begreb, dvs. ud fra forholdet mellem produktionssfære og cirkulationssfære.

Ud fra dette perspektiv viser de mulige afvigelser mellem værdi og pris sig at være bestemt af tre faktorer: totalproduktets størrelse og værdi, merværdira-

1. Tiårsoversigten 1975 , s. 61.

2. Skolen kaldes også »monitaristerne«. For en kritik af denne tolkning af pengenes rolle i totalreproduktionen se Marx: Zur Kritik der politischen Ökonomie, Dietz Verlag, Berlin 1970. s. 164 ff. Marx kritiserer her Ricardos tese om at priserne er direkte proportionale med pengemængden. En glimrende fremstilling af de borgerlige inflationsteorier findes hos Olaf E. Dombrowsky: Zur Kritik bürgerlicher Inflationstheorien, Prokla, 17/18, 1975. (På dansk i: Inflation og krise, KURASJE 1976) En kvantitetsteoretisk pengeteori findes hos Siebke/Willms: Theorie der Geldpolitik, Springer Verlag, 1974.

3. Altvater, Hoffmann, Künzel, Semmler: Inflation und krise der Kapitalverwertung, Prokla 17/18, 1975. (På dansk i: Inflation og Krise, KURASJE 1976).

4. Det drejer sig her om det keynesianske inflationsbegreb. Dette begreb er til en vis grad programmatisk: inflationen opfattes som noget positivt, nemlig som et middel til at stimulere investeringerne og dermed den $\varnothing$ konomiske aktivitet gennem profitstabilisering via prisstigninger og til at stabilisere klasseforholdene ved at reducere reallønnen indirekte og ikke gennem direkte lønpres.

Et eksempel på en keynesiansk indfaldsvinkel på inflationsproblematikken er Do Trade Unions Cause Inflation? skrevet af D. Jackson, H. A. Turner og F. Wilkonson. Cambridge. 1975. 
ten og konkurrencen mellem kapitalerne indenfor og på tværs af brancherne. Muligheden for at kapitalistklassen v.hj. af prisstigninger kan kompensere for omkostningsstigninger er afgjort af klassekampens konkrete karakter: altså af mulighederne for arbejderklassens kompensationskrav gennem lønstigninger. Her er produktivitetsstigninger en afgørende faktor, men de kan ikke anskues ud fra den relative merværdi alene, idet denne kategori- hvis den skal overføres fra det abstrakte niveau »kapital i almenhed « og anvendes direkte på historisk og økonomisk materiale - blot kan angive forholdet mellem prisen på totalproduktet og så prisen på sektor II's varer (den sektor, hvori arbejderklassens konsumtionsmidler produceres) i sammenhæng med beskæftigelsesantal og produktivitetsudvikling. Stiger priserne mere i sektor II i forhold til produktmasse end det er tilfældet i resten af samfundet, så falder merværdiraten - hvis reallønnen er konstant.

Merværdiraten som konkretere kategori - og her drejer det sig især om »relativ merværdi« da arbejdsdagen jo er konstant idag - har bl.a. den svaghed, at den forudsætter at produktivitetsudvidelse sker gennem en udvidelse af maskinparken ved konstant eller kun i ringe grad faldende arbejdstimeantal og at den forudsætter den samme produktivitetsudvikling i alle sektorer. Er denne derimod forskellig vil det ikke være sikkert, at en produktivitetsudvidelse uden videre vil skabe mere merværdi for kapitalisten heller ikke selvom hans arbejderantal er konstant. Det var jo tilfældet i England op til kornlovenes ophævelse i 1847 og videre endnu, at landbrugsprodukternes værdi overhovedet ikke fulgte værdifaldet p.g.a. produktivitetsstigninger i industrisektoren. Det betyder, at udvekslingsforholdet mellem landbrugssektor og industrisektor i en sådan situation må anskues som en konstellation, hvor industriens produktivitetsstigninger kun kan føre til stigninger i merværdiraten ved fald $i$ reallønnen. For princippet i den »relative merværdi « er, at arbejderens realløn er konstant og at dens varemasse produceres billigere end tidligere p.g.a. tekniske forbedringer af arbejdsprocessen men med ensartet timeantal, således at kapitalisten kan få en større del af produktet til sin rådighed og dermed en større del af den producerede totalværdi. Dette forhold er indlysende, når vi taler om produktionen af skjorter, der direkte indgår i arbejderens konsumtionsfond, men det bliver vanskeligere at forstå, når det drejer sig om sektor-I-varer, f.eks. aksler til motorer. Her kræves et udvekslingsforhold mellem sektorerne: hvis det samme antal arbejdere på samme tid producerer dobbelt så mange aksler som tidligere p.g.a. nyt maskineri, så er merværdiraten steget til det dobbelte, og hver aksel er faldet til den halve nyværdi (jeg udelukker her overført værdi af simpelhedshensyn). Men hvis de konsumtionsmidlereller nogle af dem der udgør arbejderens konsumtionsfond ikke er faldet i værdi i samme forhold, så kræves der så mange flere aksler til at bytte ud for de nødvendige konsumtionsmidler til arbejderen, at merværdiraten slet ikke kan stige til det dobbelte, sådan som produktionssfære-forholdene antydede det - med mindre reallønnen falder.

Kort og godt: begrebet »relativ merværdi« kan kun bruges på baggrund af den sammentænkning af produktionens og cirkulationens begreber som alene Marx' 
principper for dannelse af produktionspriser og gennemsnitsprofitrate giver det. I denne artikel vil jeg da lade merværdirateproblematikken ligge og dermed i vid udstrækning klassekampen mellem kapitalister og arbejdere i dens lønpris-perspektiv og undersøge de faktorer i konkurrencen mellem kapitalerne, der er afgørende for prisstigninger i kapitalismen i forhold til produktivitetsudviklingen.

Men selve statsinterventionsperspektivet bringer selvfølgelig klassekampen ind, idet statsintervention i f.eks. boligsektoren i vid udstrækning er en aktivitet direkte fremkaldt af klassekampen. Klassekampen er altså ikke skudt til side her, den er kun undersøgt i en af dens fremtrædelsesformer: kampen mellem de forskellige branche-kapitaler og mellem kapitalfraktionerne i samfundet i forhold til kapitalens formspecificeringer i produktionsog cirkulationssfære.

Marx' siger helt utvetydigt, at værdibegrebet først får analytisk endegyldig kraft på niveauet for kapitalen-i-dens-realitet. Her bliver det nemlig et gennemsnitsbegreb, der angiver hvor stor en del af det samfundsmæssige totalarbejde, der under givne produktionsbetingelser kan fordeles på produktionen af en brancheartikel.

»Det er i det hele taget i skikkelse af markedsprisen og videre i den regulerende markedspris' eller markedsproduktionspris' skikkelse, at vareværdiens væsen kommer til udtryk, der nemlig ikke består $i$ at være bestemt gennem den individuelle, for en given enkeltproducent nødvendige arbejdstid ved produktionen af et givet varekvantum eller af en vareenhed, men er bestemt gennem den samfundsmæssigt nødvendige arbejdstid; gennem den arbejdstid, der er påkrævet for at producere det samfundsmæssige fordrede totalkvantum af den på markedet eksisterende varetype ved de samfundsmæssige produktionsbetingelsers givne gennemsnit.« (Das Kapital, bd. III, s. 654, min overs. OFK.)

Det er altså produktionsprisen, der kvantitativt afgrænser værdibegrebet, der udgør dets historiske konkretisering ved at overordne værdiproduktionen kapitalens begreb (se kap. 2.).

Analysen af værdibegrebet kræver derfor såfremt det skal have status af udfoldet forklaringskraftig kategori inddragelsen af cirkulationssfæren og produktionssfæren, dvs. inddragelsen af totalreproduktionsperspektivet: først gennem reproduktionen af samfunds- eller totalkapitalen får værdibegrebet et særligere indhold.

Det er især i det forhold hovedargumentet for værdi-pris-identiteten over en vis periode ligger:

Idet jeg så lidt som muligt vil foregribe det følgende kapitel må dog følgende bemærkes: det ligger i kapitalens væsen, at værdi og pris ikke kan variere permanent.

Dannelsen af gennemsnitsprofitraten og produktionspriserne vil forhindre at en given branches markedsværdiniveau permanent ligger så højt at stedsevarende ekstraprofitter er mulige, for andre kapitaler vil trænge ind i branchen og dermed vil markedsværdiniveauet falde og profitten normaliseres, dvs. det, der var årsagen til værdi-pris-forskellen, vil forsvinde.

Men hvad bestemmer gennemsnitsprofitraten? Det gør totalmerværdien divideret med gennemsnitskapitalen. Da profitten immervæk må hente sit indhold fra totalmerværdien (fordi den må hente det i totalproduktionen) så findes der en »naturlig« grænse - på et givet tidspunkt- for profitniveauet både opad 
og nedad. I et lukket nationalt system, hvor vi ser bort fra kreditten og regner med at pengeudstedelsen følger produktionen (hvilket er det samme som at sige at pengeværdien er konstant - hvis vi sætter guldværdien konstant), vil kapitalens væsen altså blokere for værdi-prisforskellen som et afgørende fænomen hvad angår pris- og profitniveauets årsager over længere tid. (At produktionsprisbegrebet sætter sig igennem gennem en forskel mellem værdi og pris har intet med dette at gøre... (se fremme)).

På internationalt plan derimod bevirker det internationale betalingssystem og kreditsystem at en forskel mellem værdi og pris er mulig over et vist interval, men kun med alvorlige konsekvenser for landets økonomi.

Det er altså ikke muligt gennem prismasser, der ingen værdimæssig dækning har eller gennem »importerede« værdimasser, der ingen brugsværdidækning har i cirkulationen i det nationale system, at forøge totalmerværdien således, at profitraten kan forhøjes for alle eller blot for nogle kapitalgrupper. Det er denne artikels indhold, at påvise grænserne for forøgelsen af visse kapitalgruppers merværdi gennem en statslig omfordeling af merværdimassen og gennem udpumpning af ikkeproduktionsmæssigt-dækket købekraft i totalreproduktionen. Det er altså statens interventions-former der undersøges på baggrund af konkurrencens væsen. Kun gennem modifikation af konkurrencen kan staten gribe ind i økonomien, men modifikationen udløser blot modsigelserne på et andet plan.

Statens intervention er på længere sigt begrænset af den nationale totalmerværdi og af valget mellem to onder: forfordeling af hjemlige kapitalgrupper med social og politisk uro som resultat eller skabelsen af svagheder i handelsog betalingsbalancen. $\mathrm{Og}$ de to onder hænger desværre sammen, så et valg ikke betyder en udelukkelse af den bortvalgte mulighed.

Forudsætningen for at behandle disse problemer er udviklingen af begrebet »totalkapital,« og det kan kun ske gennem udviklingen af gennemsnitsprofitraten, altså gennem en behandling af konkurrencen.

Staten forholder sig i sidste instans til totalkapital og totalarbejderklasse, men dens holdning går gennem aktion overfor kapitalerne indenfor de enkelte brancher og arbejderne indenfor de enkelte brancher og i de enkelte forbund.

Staten kan kun kommunikere med kapitalen sådan som kapitalen fremtræder i konkurrencen, det er dér deres tosomhed fuldbyrdes og parringen sker i sidste instans på kapitalens betingelser.

Skal man forstå hvordan staten handler i kapitalismen kan det da ikke nytte at opfinde en totalkapital som den handler overfor som sin partner - det er et fatamorgana, der smugler en rationalitet ind i historien, der ikke findes der. Staten må forholde sig til kapitalen som en branchespecifik og sektorspecifik kapital og som en kapital afgørende bestemt af de formbestemmelser den annammer i cirkulationssfæren.

Som sådan gribes forholdet da også her og artiklens pointe er da at forstå noget af inflationens væsen som fremkaldt af den interventionsnødvendighed, 
der ligger i statens væsen som formidler af modsætningen kapitalarbejde: Statens politisk bestemte efterspørgsel på produkter fra en række brancher i samfundet skaber konkurrencebetingelser i disse brancher, der bevirker, at der kan eksistere et meget højt markedsværdiniveau, små uproduktive virksomheder, og at de virksomheder, der har udviklet en høj produktivitet kan realisere store og stabile ekstraprofitter.

Herved såres princippet for dannelsen af gennemsnitsprofitraten i samfundet og de kapitalgrupper, der ikke nyder godt af statens efterspørgsel, kræver frihed, lighed og broderskab for alle kapitaler.

Det væsentlige her er bl.a., at der ikke er tale om nogen monopolsituation i den forstand, at brancherne skulle kunne lægge deres eget prisniveau eller råde over deres leverancer, etc. Prisniveauet er fuldkommen bestemt af efterspørgsels- og udbudsmekanismen og der siver kapital i rigt mål til brancherne.

Eksistensen af disse priviligerede brancher skaber en relativ stigning i omkostningsniveauet i samfundet og forværrer dermed kapitalernes situation både på hjemmemarkedet og på verdensmarkedet.

Før den egentlige fremstilling begynder er det på sin plads at begrunde, hvorfor jeg mener at inflationen som en af sine årsager har opretholdelsen af et kunstigt højt markedsværdiniveau og dermed som sin »materie « har »falsk social værdi« og ikke produceret værdi. (Disse begreber præciseres indgående i næste kapitel). Det er altså rimeligt kort at anføre, hvilke løsningsmuligheder jeg på forhånd har udelukket:

I) En årsag til den stigende priskurve i senkapitalismen kunne være det forhold, at simpelt arbejde forvandledes til kompliceret arbejde, dvs. at prismassen var dækket ind af en værdimasse, der faktisk var produceret.

En sådan antagelse, der bl.a. formuleres af S. L. Wygodski ${ }^{5}$, er totalt uacceptabel fordi den sammenblander produceret og realiseret merværdi. Ifølge den skulle ekstraprofitterne realiseret på grundlag af et givet markedsværdiniveau af de højproduktive firmaer være producerede. Det ville kort og godt betyde at totalmerværdimassen var uendelig at der ingen grænser fandtes for den, og at gennemsnitsprofitten ikke skabtes gennem en forskel mellem pris og værdi. Det ville betyde et opgør med hele værditeorien og en tilbageførsel af denne til Ricardos perspektiv, hvor der ikke systematisk sondres mellem individuel og samfundsmæssig nødvendig vareværdi. Endelig ville det bryde med hele Marx' akkumulationsteori og indebære at profitraten var absolut stigende i takt med akkumulationen. ${ }^{6}$

5. S. L. Wygodsky: Der gegenwärtige Kapitalismus, Versuch einer theoretischen Analyse, Pahl-Rugenstein, 1972.

6. Hvis man accepterede, at det var produceret værdi, der lå til grund for ekstraprofitterne, så ville man gøre profitten direkte proportional med v's størrelse og ikke med k+v, sådan som Marx tænker profitdannelsen i konkurrencen, hvor profitten netop er proportional med kapitalens absolutte størrelse uafhængigt af v's absolutte og relative størrelse. En sådan tese forudsætter enten at ligestore kapitaler ikke afkaster samme profit, med mindre de har præcis samme 
Flere argumenter er næppe nødvendige og fremstillingen i de næste kapitler vil forhåbentligt belyse det umulige i denne antagelse. Ellers vil jeg henvise til Ole Marquardts originale bidrag i Fagtryk. ${ }^{7}$

II) At prismassens stigning værdimæssigt skulle være dækket ind af faldende produktivitet eller stigende arbejdsintensivering er naturligvis en mulighed, men for det første er denne i modsætning til hele akkumulationsimperativet og dets måde at sætte sig igennem på i enkeltkapitalernes konkurrence. Desuden er de i modstrid med de empiriske data for de brancher, hvori prisniveauet er højest. Her foregår hele tiden en udvidelse af produktiviteten på arbejdets bekostning. Jeg henviser her igen til argumentationen i de kommende kapitler.

III) Endnu en mulighed for at forklare prisstigningerne i kapitalismen omvendt proportionalt med de faktiske produktivitetsstigninger ville være en tese om monopoliseringens store udbredelse og dens ineffektivitet i forhold til udviklingen af de samfundsmæssige produktivkræfter. Denne tese, der hører til »stamokaps « regi, men som også kan findes hos Hofmann og Baran-Sweezy, findes alene renset for sit politicistiske perspektiv på værdiloven og kapitalens jernhårde lovmæssigheder hos S. L. Wygodski. Denne forklarer monopolernes indvirkning på prisdannelsen gennem faktorer som bremsning af output, produktion ved underkapacitet, stigning i arbejdets udbytningsgrad, faktorer, der kan få markedsværdierne til at forblive konstante eller stige alt efter priserne på råvarer, maskiner og arbejdskraft. Ifølge Wygodski sker de faktiske produktivitetsstigninger i virksomheder udenfor monopolerne, hvor de sidste så bagefter overtager den nye teknik og udnytter den i begrænset grad alt efter profitniveauet.

Denne tese kan have en vis berettigelse i afgrænsede sammenhænge, men den rummer elementer der overser den udviklingssammenhæng, der ligger i kapitalens væsen. Samtidig mangler den evne til en systematisk belysning af statsinterventionismen og endelig er den empirisk irrelevant ved behandlingen af Danmarks erhvervsstruktur efter anden verdenskrig.

Hvorom alting er: den kapitalistiske udvikling, der udgør en udbredelse af kapitalrelationen til at dække hele samfundet og går i retning af at underlægge sig hele verdensøkonomien med ganske få - og væsentlige undtagelser - og der går i retning af en koncentration og vækst i den konstante kapital overfor arbejdskraften, denne udvikling sætter sig dog kun igennem via udviklingen i kapitalerne indenfor de enkelte brancher. Det er dér arbejderklassen møder kapitalen og det er herigennem kapitalen gennem sin organisering af produktionen af brugsværdier afgørende påvirker totalreproduktionen, og gør den til en reproduktion af sig selv i form af produktionsmidler og konsumtionsvarer.

arbejderantal af samme komplicerthedsgrad, eller at de - hvis de afkaster samme profit - enten tilfældigvis netop beskæftiger samme forhold kompliceret og simpelt arbejde, eller fordi den ene kapital beskæftiger en stor mængde simpelt og en lille mængde kompliceret arbejde, hvilket ækvivalerer med en vis mængde halvkompliceret arbejde.

7. En kommentar til den såkaldte reduktionsproblematik og dennes betydning for den marxske arbejdsværditeori. Fagtryk februar 1975. 


\section{Kapitel 2}

\section{Konkurrencens begreb}

Et udviklet samfunds produktion er opdelt i forskellige sektorer, der kendetegnes af produktionens formål i reproduktionens totalproces: landbrugssektor, bygge- og anlægssektor ect. Disse sektorer, der i den borgerlige bevidsthed afgrænses direkte efter dagligdagserfaringerne - og hvis videnskabelige berettigelse ikke skal diskuteres her - kan igen opdeles i brancher. Indenfor industrisektoren ${ }^{1}$ findes der f.eks. klynger af brancher, hvori der produceres kemiske artikler, elektroniske artikler, ect. og disse klynger kan igen opdeles i brancher, der afgrænses af et givet produkt: produktion af f.eks. batterier eller sovetabletter.

Branchebegrebet er altså afhængig af muligheden for at sammenligne en given produktion kvalitativt og kvantitativt, således at man kan udgå fra, at der vil dannes en enhedspris på produktet. Branchebegrebet er altså også afhængig af at branchens produkter har akkurat samme funktion indenfor den produktive eller private konsumtion.

Lad os i det følgende som eksempel på en branche tage cykelbranchen. Denne branche består måske af 9 virksomheder, der kan inddeles i 3 grupper på hver 3 virksomheder efter den organiske sammensætning af kapitalen $\mathrm{i}$ disse virksomheder ${ }^{2}$.

Vi kan nu opstille følgende skema hvis hver kapital antages at være på hundrede, eller hvis vi ser på hver kapital som et udsnit af 100. Den kapital der opereres med er overført kapital, d.v.s. at vi betragter den masse konstant og variabel kapital, der overføres til produktet gennem en dags produktion. At den egentlige kapital kan være større er selvsagt indlysende, men det spiller ingen rolle for argumentet. Vi antager også, at m' er konstant.

1. Marx opererer med to eller tre sektorer i sin reproduktionsmodel, hvor han udgår fra hovedkomponenterne i produktionsprocessen: produktionsmidler og arbejdskraft og således har en produktionsmiddels- og en konsumtionsmiddelsektor. Men han opererer også undertiden med en tredie sektor, der dækker kapitalistklassens konsumtion, altså produktionen af luksusvarer.

Men i sin behandling af jordrenten stiller han landbrugssektoren og industrisektoren overfor hinanden, en modsætning, der går på tværs af det egentlige sektorbegreb i reproduktionsskemaerne.

2. Det er her afgørende, at »organisk kapitalsammensætning « refererer til »teknisk sammensætning «, altså at ens organisk sammensætning i systematisk forstand går på ens produktionskoefficienter. Dette understreges i kapital 10 og 11 i bd. III af Das Kapital og i behandlingen s. 774 af bd. III af Das Kapital.

For en god behandling af forholdet mellem værdimæssig og teknisk sammensætning af kapitalen, se Grossmann: Das Akkumulations- og Zusammenbruchsgesetz des kapitalistischen Systems, Archiv Sozialistischer Literatur 8, Frankfurt, 1970, s. 326-334. 


\begin{tabular}{|l|c|c|c|c|}
\hline Kapitaler & $\mathrm{m}{ }^{\prime}$ & $\mathrm{m}$ & vareantal & $\begin{array}{c}\text { individuel } \\
\text { vareværdi }\end{array}$ \\
\hline A: $90 \mathrm{k}+10 \mathrm{v}$ & $100 \%$ & 10 & 10 & 11 \\
B: $50 \mathrm{k}+50 \mathrm{v}$ & $100 \%$ & 50 & 5 & 30 \\
C: $20 \mathrm{k}+80 \mathrm{v}$ & $100 \%$ & 80 & 1 & 180 \\
\hline
\end{tabular}

Hvis varerne sælges til deres individuelle værdi, og hvis hele denne realiseres, vil hver af kapital A's cykler blive solgt til værdien 11, B's til værdien 30, og C's til værdien 180. Af det antal cykler, som hver kapital producerede dagligt, fremgår det, at produktiviteten er direkte proportional med kapitalens organiske sammensætning: jo højere den er, desto højere er antallet af dagligt producerede enheder.

Problemet er nu, at enhver brancheartikel tenderer mod at blive solgt til en ensartet pris. Det er nemlig klart, at A ikke vil sælge sine cykler til en pris, der ligger på 11, når han ser at $\mathrm{C}$ sælger præcis den samme cykel til 180, altså til en værdi der ligger 16 gange over hans egen, ejheller vil vel nogen normal forbruger betale 16 gange så meget for den samme cykel?

Gennem den logiske mulighed for en afvigelse mellem pris og værdi - altså gennem det forhold, at en given pris ikke med logisk nødvendighed behøver udtrykke værdi, - vil der kunne dannes en enhedspris for ethvert brancheprodukt uafhængigt af den individuelle værdi af de varer, der produceres i branchen, eller rettere: afhængigheden viser sig indirekte gennem de love, hvorigennem vareværdierne regulerer priserne. Disse love ligger indenfor værditeoriens område, og derfor skal jeg i det følgende belyse, hvordan værdiens regulering af prisniveauet i brancherne og i hele samfundet faktisk sætter sig igennem.

Udgangspunktet er her det forhold, at pris og værdi, merværdi og profit kan variere på brancheplan, og må variere for at den dynamik, der ligger indbygget i kapitalens begreb kan fuldbyrdes: at kapitalen er værdiavlende værdi. Denne dynamik er kun helt gennemført i det øjeblik kapitalen kan afkaste profit i direkte forhold til sin absolutte størrelse, altså ikke blot i forhold til den arbejdermasse - ved given merværdirate ${ }^{3}$ - den kommanderer over. Dannelsen af en gennemsnitsprofitrate ligger således indbygget i kapitalens begreb, men

3. Årsagerne til at merværdiraten kan sættes konstant både empirisk og logisk behandles indgående i artiklen, her skal de kort ridses op:

Merværdiraten er konstant af logiske hensyn, fordi det ellers ikke er muligt at skelne mellem relativ merværdi og ekstra-merværdi og fordi man ellers ikke kan afgrænse værdibegrebet kvantitativt, men opfatter kompliceret arbejde som mere værdiproduktivt end enkelt arbejde. Empirisk set må merværdiraten være konstant, fordi det er fra sektor II at arbejderens konsumtionsfond hentes, og fordi produktiviteten er nogenlunde ensartet i denne sektor over en vis periode ifølge loven for dannelsen af gennemsnitsraten og produktionspriserne, og det gælder selvom sektor II jo delvis består af landbrugssektoren og selv om produktiviteten kan være lavere der. Thi forholdene er dog ens for resten af samfundet, og for sektor II selv, da kun en forsvindende del af al løn idag betales i naturalier. 
kan kun fuldbyrdes på præmisser, der gør det umuligt, at der faktisk kan realiseres ens profitter af alle kapitaler indenfor en branche. I kapitalens dynamik ligger, at branchekapitaler ${ }^{4} m a ̊$ have forskellig organisk sammensætning og dermed forskellig produktivitet - for ellers ville konkurrencens begreb være ophævet, det forhold altså være ophævet at enhver kapital ifølge sit væsen må søge at maximere sin profit absolut. Loven om dannelse af gennemsnitsprofitraten betyder da, at en kapital med en given sammensætning, altså med en given produktivitet per 100, vil kunne anbringes med samme profit i alle brancher, hvis brancherne betragtes i deres udvikling over en vis periode.

I det følgende skal disse forhold nøje udpensles:

Bestemmende for niveauet for enhedsprisen indenfor cykelbranchen over en vis periode er følgende faktorer:

Virksomhedsantallet i branchen, virksomhedernes størrelse og organiske kapitalsammensætning (produktivitet) og efterspørgslen ${ }^{5}$ på brancheproduktet, disse faktorer bestemmer udbuddets kvalitet og kvantitet.

Lad os for simpelheds skyld fortsat antage, at de 9 firmaer i branchen alle er lige store (100), og at de er inddelt i 3 grupper med hver sin organiske sammensætning, nemlig henholdsvis 9:1, 5:5 og 2:8. Hver virksomhed antages også at producere et forskelligt antal produkter, således at de virksomheder med den største konstante kapitaldel producerer mest.

Hvis vi nu antager at udbud-efterspørgselsmekanismen er i hvile, harmoni, så antager vi også definitorisk, at prisen på cykler vil blive reguleret som et aritmetrisk gennemsnit af totalværdien af cyklerne og af deres antal. ${ }^{6}$ Denne definitoriske antagelse svarer til virkeligheden i den forstand, at udbud-efterspørgselsharmonien selvfølgelig ikke er et statisk begreb - som hvilket det blot illustratorisk af hensyn til tallenes simpelhed fremstilles her - men en tendensstørrelse, udtryk for et realt gennemsnit, der går ud på, at virksomhedsantal og produktivitetsniveauer $\mathrm{i}$ alle brancher har en tendens til at blive ensartede p.g.a. kapitalens indog udsivning i brancherne alt efter hvor profitten på en given kapitalsammensætning for tiden er størst. At udbud-efterspørgselsmekanismen harmonerer betyder altså ikke andet end, at nogenlunde de samme afvigelser i retning af højere og lavere organiske sammensætninger hos kapitalerne over en vis periode vil kunne findes mellem alle brancher. I realiteten betyder det altså, at man kan se bort fra udbud-efterspørgselsmekanismen ved konstitueringen af det gennemsnitlige prisniveau i brancherne, og at det her er kapitalernes produktivitetsudvikling, der er primus motor. ${ }^{7}$ Følgende skema kan da opstilles:

4. i.e. kapitaler indenfor samme branche.

5. Efterspørgslen skal i det følgende forblive en uforklaret størrelse indtil den i Del II vil blive belyst i forbindelse behandlingen af sammenhænge mellem gennemsnitsprofitrate og totalreproduktion.

6. Angående en bestemmelse af begrebet »aritmetrisk gennemsnit« se Nørgård: Nationaløkonomi, Appendix: Elementær praktisk statistik.

7. Se Ole Fogh Kirkeby: Kapitallogik og historie. RUC-forlag og Boghandel, 1975, Del II. 


\begin{tabular}{|l|c|c|c|c|c|c|}
\hline Kapitaler & m' & $\mathrm{m}$ & vareantal & $\begin{array}{c}\text { individuel } \\
\text { værdi }\end{array}$ & $\begin{array}{c}\text { enheds- } \\
\text { pris }\end{array}$ & $\begin{array}{c}\text { afvigelse } \\
\text { mellem pris } \\
\text { og værdi }\end{array}$ \\
\hline A: $90 \mathrm{k}+10 \mathrm{v}$ & $100 \%$ & 10 & 10 & 11 & 27,5 & $+16,5$ \\
B: $50 \mathrm{k}+50 \mathrm{v}$ & $100 \%$ & 50 & 5 & 30 & 27,5 & $-2,5$ \\
C: $20 \mathrm{k}+80 \mathrm{v}$ & $100 \%$ & 80 & 1 & 180 & 27,5 & $-152,5$ \\
\hline
\end{tabular}

Enhedsprisen på cyklerne bliver 27,5, hvis vi altså antager, at denne bestemmes af det aritmetriske gennemsnit af totalproduktværdien fra de 3 kapitaltyper og det samlede antal produkter. Ved salget af kapital A, B og C's varer til denne pris vil kapital A realisere en ekstramerværdi på 16,5, kapital B vil miste 2,5 af sin producerede merværdi, og kapital C vil miste 152,5 af sin producerede merværdi.

Ved realiseringen af produkterne, altså gennem deres ophold i cirkulationssfæren, har den producerede værdi gennemgået en forvandling. Denne forvandling, der foregår gennem etableringen af en enhedspris for produktet, korrigerer den individuelle arbejdsmængde, der er blevet anvendt til at fremstille produktet i den enkelte virksomhed og gør værdiproduktion til et totalt fænomen ved at indføre en objektiv norm for den arbejdstidsmasse, der kan anvendes på det enkelte produkt.

I det her behandlede eksempel, hvor udbud-efterspørgselsmekanismen skal harmonere, vil enhedsprisen ligge tæt op af den kapitals produktværdi med den mellemste organiske sammensætning (kapital B), fordi kapital C's enkelte produkt vejer så tungt ud fra sin lave produktivitet, at der skal mange produkter til fra en kapital med høj produktivitet for at opveje det. Og »opvejes« skal det jo, da dette eksempel netop forudsætter at summen af branchepriserne er identiske med summen af brancheværdierne. Enhedsprisen indenfor en branche kalder Marx for »markedsværdien«.

\subsection{Markedsværdiens begrebslige status}

Markedsværdien er et begreb, der er begrænset til prisniveauet indenfor en branche ${ }^{8}$.

Markedsværdien er i vid udstrækning et »realt« begreb, d.v.s. at den kan konstateres direkte i de konkrete prisstørrelser på markedet, omend med visse modifikationer. Disse modifikationer bringer Marx ind, når han skelner mel-

8. Der er vanskeligheder forbundet med det at tale om »markedsværdier«, indenfor en sektor, da markedsværdibegrebet forudsætter et produkt, der er ensartet både hvad angår de stoflige betingelser for dets produktion og de former, hvori det indgår i den produktive eller private konsumtion. Men der er forhold, der taler for at man kan tale om markedsværdi i forbindelse med visse sektorer, f.eks. boligsektoren, sådan som der argumenteres for det i det følgende kapitel om denne sektors problemer. 
lem markedspris og markedsværdi, og her præciseres markedsprisen som de tilfældige afvigelser fra markedsværdien, der kan være i prisbevægelserne, altså som de videnskabeligt uinteressante bestemmelser for værdibevægelsen indenfor en branche. ${ }^{9}$ Markedsværdien viser, at priserne på brancheproduktet er reguleret af værditeoriens lovmæssigheder. Men denne regulering tager en særlig form: markedsværdien er nemlig i det enkelte tilfælde (salg) sjældent dækket værdimæssigt ind.

I det tilfælde vi her har behandlet, hvor udbud-efterspørgselsmekanismen var i hvile, var den totalprismasse som realiseredes gennem markedsværdien dækket ind af totalproduktets værdi i branchen på en dag. Men generelt vil udbud-efterspørgslens harmoni være en tendentiel bevægelse, hvilket betyder, at den prismasse, der realiseres gennem markedsværdierne indenfor en branche $\mathrm{i}$ et givet kort interval logisk set $i k k e$ behøver at være dækket ind af en værdiproduktion, og generelt sjældent vil være det.

Det sidste skema viser, at markedsværdien 27,5 for kapital A's vedkommende indebærer et salg af produkterne over for deres individuelle værdi, og dermed realiseringen af en merværdimasse, der ligger langt over den producerede merværdi hos denne kapital, nemlig 10 varer à $27,5=270 \div 110=165$. Men af skemaet så vi altså også, at selvom der var tale om en omfordeling af den producerede merværdi, så forblev det omfordelte indenfor denne værdis kvantitative rammer: Totalværdien af produktet $=300+140$ (totalmerværdi $)=$ 440 , mens det realiserede produkt har værdien: $16 \times 27,5=440$.

Gennem realiseringen af brancheproduktet ved udbudsefterspørgselshvile viser det sig, at profitraten for de enkelte kapitalgrupper ændrer karakter fra den, den havde i produktionsprocessen:

\begin{tabular}{|l|c|c|c|c|}
\hline Kapitaler & $\mathrm{m}^{\prime}$ & $\mathrm{m}$ & $\begin{array}{c}\text { p'i produktions- } \\
\text { processen }\end{array}$ & $\begin{array}{c}\text { p' i realisations- } \\
\text { processen }\end{array}$ \\
\hline A: $90 \mathrm{k}+10 \mathrm{v}$ & $100 \%$ & 10 & $10 \%$ & $165 \%$ \\
B: $50 \mathrm{k}+50 \mathrm{v}$ & $100 \%$ & 50 & $50 \%$ & $37,5 \%$ \\
C: $20 \mathrm{k}+80 \mathrm{v}$ & $100 \%$ & 80 & $80 \%$ & $-152,5 \%$ \\
\hline
\end{tabular}

Hvis hver enkelt kapitalgruppes hele produktmasse sælges til markedsværdien 27,5, får de altså en helt anderledes profit end de iflg. deres merværdiproduktion skulle.

Af dette følger bl.a.:

Hvis brancheproduktet realiseres til markedsværdien, hvis kapitalerne tænkes med forskellig organisk sammensætning og hvis denne skal komme til udtryk i forskellig produktivitet, altså i forskellig produktmasse, så kan der

9. Se Das Kapital, bd. III, kapitel 10. 
aldrig dannes samme profitrate hos de forskellige kapitalgrupper indenfor en branche.

Indenfor branchen udgør dette forhold kernen $\mathrm{i} »$ konkurrencens begreb «:

Dennes væsen består i det forhold, at hver kapital søger at erhverve sig så stor en profit som muligt gennem salget af sine varer til de højest tænkelige priser. Kun ydre tvang, af samfundsmæssig eller naturmæssig art, der nivellerer produktivitetsniveauet og indfører ensartet sammensatte kapitaler, kan skabe samme profitrate på alle kapitaler indenfor en branche.

Når markedsværdien ved udbud-efterspørgselsharmoni var 27,5 og denne pris var en pris, der ikke svarede til nogen af de 3 kapitalgruppers individuelle produktværdi, så kan det synes et problem hvordan denne pris opstår.

Den opstår som følge af kapitalistens følen sig frem.

Egentlig kan prisbevægelsen jo kun anskues historisk (diakront), d.v.s. man må her starte med prisbevægelserne set i relation til køretøjets (cyklens) historie indenfor produktions- og konsumtionsprocessen. Men for vores logiske (synkrone) betragtning er brancheproduktets markedsværdi noget altid-allerede-givet, en størrelse, der udvikles som den fremtræder for enkeltkapitalens bevidsthed.

For denne gælder det, at begrebet merværdi ikke eksisterer. Man kan højst sige at begrebet »relativ merværdi« kan have en vis fænomenologisk status som det vage forhold mellem kapitalistklasse og arbejderklasse udtrykt i forholdet mellem bevægelser i lønniveauet og salgsprisen for brancheproduktet.

Enkeltkapitalen kender kun begrebet omkostningspris og så begrebet profit, og sætter ikke de to systematisk i relation til hinanden gennem begrebet merværdi. Sådan en forbindelse er en ideel, abstrakt konstrueret forbindelse, der hører hjemme på niveauet-for-kapital-i-almenhed og ikke kan anvendes til at forklare konkurrencens fænomener.

Kapitalisten ved altså simpelthen ikke hvad den individuelle værdi af hans produkt er, og derfor sætter markedsværdien sig igennem i enhedsprisen for produktet ved at udtrykke sig i kapitalstens anelser og fornemmelser af hvad han kan tage for sin vare, d.v.s. hvor meget over omkostningsprisen han kan sætte sin pris uden at få noget restlager. Dermed vil hans handlinger altid være bestemte af hans relation til andre kapitalister, altså til de mere og mindre produktive kapitaler, således at markedsværdiniveauet er udtryk for en prisfastsættelse, der er resultatet af et permanent spændingsforhold ${ }^{10}$.

Hvis vi nu forlader antagelsen af en harmoni i udbud-efterspørgslen på cykler og f.eks. antager, at efterspørgslen i udtalt grad overstiger udbuddet, så vil - hvis stigningsgraden er tilstrækkelig stor -markedsprisen kunne blive identisk med kapital C’s individuelle produktværdi, altså ligge på 180.

10. Jeg er her bort fra prisaftaler, der dog i vid udstrækning kan afledes af den rene konkurrences begreb. 
De 16 cykler, der laves i branchen på en dag vil da kunne sælges til totalværdien 2880, altså 2440 over den værdi de har når de kommer ud af produktionsprocessen.

Kapital A og B vil da kunne realisere enorme ekstraprofitter, nemlig henholdsvis: 1690 og 750 .

Hvis derimod efterspørgslen på cykler falder drastisk, så vil det måske ende med at kapital A's individuelle produktværdi regulerer markedsprisen, og så vil kapital $\mathrm{B}$ og $\mathrm{C}$ ikke alene sætte deres producerede merværdi til, men også blive blokeret i reproduktionen af deres kapital.

I første tilfælde vil der være realiseret meget mere værdi indenfor branchen end der er produceret i den. Marx kalder denne ekstra-realiserede værdimasse for »falsk social værdi«. Vi vender tilbage til dette begreb i næste afsnit.

Men enkeltkapitalistens fornemmelser for hvad han kan tage for sin cykel er mere end en fingerspitzgefühl. Han har nemlig profitterne i de andre brancher til at assistere sig ved programmeringen af sit profitniveau. (Hvad enten han nu snakker med sine kolleger i de andre brancher, studerer aktiemarkedet, prisudvikling, ect.) Hvis han nu synes, at hans kapital per 100 burde give mere profit i forhold til sin sammensætning - fordi dette er tilfældet i nogle andre brancher - og han p.g.a. udbuddets størrelse og efterspørgslens faldende tendens ikke kan sætte sine priser op, så kan han flytte sin kapital til en anden branche, hvor en kapital per 100 med samme sammensætning giver større profit, eller han kan ændre sin egen kapitals sammensætning i retning af en forøgelse af k-delen med henblik på yderligere produktivitet.

Omvendt vil kapitaler fra de andre brancher gennem salg af deres maskiner og bygninger eller via lånemarkedet sive ind i cykelbranchen hvis profitbetingelserne er særlige gunstige der: hvis f.eks. markedsværdiniveauet er så højt at man med en relativt lille kapital eller en relativt lav sammensætning kan opnå ekstraprofitter. Naturligvis vil virkningen af en sådan indsivning være, at markedsværdiniveauet falder, fordi udbuddet stiger, og således nivelleres ekstraprofitniveauet atter.

Resultatet af denne ind- og udsivningsproces er, at der tendentielt indenfor brancherne vil være samme profitniveau ved samme kapitalsammensætning - de stoflige forskelle undtaget. Men dette er faktisk udtryk for en tendens, og på et givet tidspunkt vil en given sammensætning indenfor en given branche kunne give meget store ekstraprofitter. Pointen er bare, at dette forhold ikke kan være permanent.

\subsection{Produktionspris-begrebet}

Gennem denne ud- og indvandring af kapital - der selvfølgelig er afhængig af mulighederne for at frigøre kapital, låne kapital og for at kunne omsætte denne kapital i pengeform til produktionsmidler - vil der i alle brancher dannes et gennemsnitligt profitniveau - siger Marx. 
Hvor vi slog fast, at branchen iflg. konkurrencens begreb vil være kendetegnet af det forhold, at der vil være forskellige profitter, så er samfundet som helhed kendetegnet ved det forhold, at der mellem brancherne vil være tendens til at dannes et ensartet profitniveau, men dette profitniveau foreligger aldrig som en statisk størrelse, som noget permanent:

Derfor kan Marx betegne gennemsnitsprofitraten som »et sløret tågebillede« (Das Kapital, bd. III, s. 381), sige, at den fremtræder alene som »profittens minimalgrænse, ikke som empirisk, direkte synligt udtryk for den virkelige profitrate«. (ibd. s. 380).

For hvis gennemsnitsprofitraten skulle være statisk, noget ikke fluktuerende, engang-for-alle etableret, så skulle der herske samme markedsværdiniveau og samme produktivitetshierarki indenfor hver branche: samme antal firmaer fordelt på kapitalgrupper med samme organiske sammensætning.

Men dette er en tilstand, som medføres af kapitalerne i deres bevægelse mod den uendelige profitmaksimering, dog det er kun en tendens, et ideelt gennemsnit, det kan aldrig blive en tilstand - især fordi det indebærer at alle produktionsprocesser har samme stoflige betingelser for organisk kapitalsammensætning.

»Derimod kan profitraten (Marx sammenligner profitraten med den almene rentefod) selv indenfor den samme branche ved ens markedspriser være forskellig, alt afhængig af de forskellige betingelser, hvorunder de enkelte kapitaler producerer den samme vare; thi profitraten hos enkeltkapitalen bestemmes ikke gennem varens markedspris, men gennem forskellen mellem markedspris og omkostningspris. Og disse forskellige profitrater, først indenfor den samme branche og så mellem de forskellige brancher, kan kun udlignes gennem bestandige svingninger«. (Das Kapital, bd. III, s. 381-382. Min overs. OFK)

Hvis man alligevel vil opfatte gennemsnitsprofitraten som en real størrelse af en eller anden art - og det gør Marx faktisk i sammenhæng med det ovenfor citerede, ved at sige, at »Den almene profitrate fremtræder derfor faktisk som empirisk, givet faktum i den gennemsnitlige rentefod, selvom den sidste ikke er et rent eller tilforladeligt udtryk for den første« (Das Kapital, bd. III, s. 377-378), - så kan det kun lade sig gøre ved at man udgår fra det forhold, at et givet brancheprodukt generelt produceres ved en herskende produktionsteknik - hvorfra der så er bedre og dårligere afvigelser - hvad angår kapitalsammensætning - og derfor vil profitniveauet $\mathrm{i}$ en række brancher reguleres af de virksomheder der - i kraft af deres antal og sammenhæng med den almindelige udvikling af teknikken - ligger på dette typiske produktivitetsniveau. Men her er der nok alligevel så mange afvigelser fra reglen, at Marx's sammenligning mellem rentefod og gennemsnitsprofitrate er en mere holdbar tese, fordi den jo faktisk næsten indskrænker sig til at sige, at rentefoden bestemmes af forholdet mellem totalkapital og totalmerværdi.

Konklusionen her må da være, at der på et givet tidspunkt vil kunne konstateres ret forskellige profitrater i de forskellige brancher i samfundet alt efter udbud-efterspørgslens karakter og efter de stoflige betingelser for produktionen, men denne tilstand kan ikke være langvarig i betydningen: de brancher hvis profit 
lå under gennemsnittet vil forøge deres profit ved at udbuddet gennem kapitaludvandring falder, og de kapitaler, der lå over profitniveauet vil miste noget profit gennem udbuddets forøgelse, fordi der siver kapitaler til. Her må man dog sige: hvad er det for et profitniveau, man taler om at profitten ligger »over« eller »under«, og hvis svaret ikke skal være rent historisk, altså angå relative prisbevægelser, så er det absolutte prisniveau naturligvis det, der bestemmes af den profitmasse som branchen - ifølge den del dens totalkapital udgør af den samfundsmæssige totalkapital - burde have. Og den kan naturligvis bestemmes ud fra forholdet mellem produceret værdi i branchen og produceret værdi i samfundet som helhed.

Pointen er altså, at de priser, der gør gennemsnitsprofitraten mulig ikke er priser, der kan konstateres gennem et snit på tværs af tiden, men er afhængig af den tidsmæssige udfoldelse: gennem kapitalbevægelserne indenfor og mellem brancherne er der tendens til at ens sammensatte kapitaler vil kunne anbringes med nogenlunde samme profit i alle brancher, hvilket er det samme som at sige at ligestore kapitaler med forskellig sammensætning vil tendere mod at give samme profit indenfor brancherne. Paradokset, der tilsyneladende ligger heri er kun tilsyneladende, for det sagte betyder blot: $i$ en given branche vil konkurrencen bevæge sig således fremad, at de lavt sammensatte kapitaler vil afskaste mindre profit end den merværdi de ved konstant merværdirate ifølge deres variable kapitals størrelse giver, og de kapitaler, der er højt sammensat vil tilegne sig mere profit end den merværdi de faktisk producerer.

Det betyder, at alle brancher logisk set på et eller andet tidspunkt må befinde sig i en sådan situation, at højt sammensatte kapitaler giver ekstraprofitter, men det betyder ikke at alle brancher på samme tidspunkt giver præcis samme profit til samme kapitalsammensætning.

De priser, der gør det muligt, at alle kapitaler gennem deres interaktion tenderer mod at sælge til priser, der gør realiseringen af en gennemsnitsprofit mulig, kalder Marx for, at der dannes produktionspriser mellem brancherne.

Sætter en kapitalist en kapital med en given kapitalsammensætning per 100 ind i en branche på et givet tidspunkt, så vil den profit som denne kapital giver være afhængig af markedsværdiniveauet på det givne tidspunkt, altså være afhængig af antallet af virksomheder, deres produktivitet og endelig af udbud efterspørgsels-mekanismens tilstand. Placeringen af kapital i denne branche kan altså på et givet tidspunkt give langt mere end placeringen af præcis den samme mængde og ens sammensatte kapital i en anden branche. Men i selve placerings-processen ligger den virkning indbygget, der gør at lige store kapitaler vil afkaste samme profitter over en vis periode: thi kapital-placeringen i branchen vil ændre udbuddets karakter, den relative produktivitet, etc.

Hermed er ment det forhold, at to kapitaler gennem direkte handel med hinanden - såfremt disse kapitaler tilhører hver sin branche med hver sit markedsværdiniveau - i deres bytteakt vil opføre sig således, at den kapital, hvis produktivitet ligger langt over gennemsnittet og hvis markedsværdiniveau ligger langt under 
markedsværdiniveauet i det $\varnothing$ vrige samfund, vil realisere sine varer til en værdi, der ligger langt over den individuelle værdi af produktet. Gennem udvekslingen af to brancheprodukter - v.hj. af den almene ækvivalent - vil der altså ske en »værdioverførsel $\ll$.

Men denne værdioverførsel har alligevel i vid udstrækning karakter af et forhold, der sætter sig igennem som en tendens. Værdioverførsel betyder slet og ret, at en branche p.g.a. sin højproduktive kapital kan sælge produktet over dets individuelle værdi, fordi der er et samfundsmæssigt behov for det, og fordi produktivitetsniveauet i de andre brancher har så ensartet en karakter, at det lægger en norm for et gennemsnitligt kapitalafkast.

»Værdioverførsel« skal altså ikke forstås som et begreb for en sindrig form for værdi-udvekslingsmekanisme i en bytteakt mellem to sektorer, men ud fra forholdet mellem en branche og totalmassen af arbejde i samfundet: værdioverførsel betyder, at der anvendes mere arbejde i en række brancher end der ud fra et samfundsmæssigt rationelt synspunkt burde. Det gør, at de brancher, hvori det menneskelige arbejde anvendes med optimal rationalitet, d.v.s. hvor det er mest produktivt, at disse brancher er atypiske i forhold til niveauet for det samfundsmæssigt nødvendige arbejde i de andre brancher, og derfor kan realisere en profit, der svarer til en lavere akkumulationsgrad ${ }^{11}$.

Kernen i Marx's begreb for produktionsprisen går ud på, at de virkelige ekstraprofitter realiseret indenfor brancherne altid udspringer af branchens relation til udviklingen af det menneskelige arbejde i de andre brancher: enten udspringer ekstraprofitterne af det forhold, at branchens produktivitet ligger under eller over gennemsnittet i samfundet eller af det forhold, at den kapital, der realiserer ekstraprofitten har en meget høj sammensætning - et forhold der mere er specifikt for kapitalen selv end for branchen. Forudsætningen for ekstraprofitterne er det forhold, at værdi og produktionspris principielt ikke falder sammen.

»Produktionsprisen og den almene profitrates eksistens og begreb, beror på det forhold, at de enkelte varer ikke sælges til deres værdi. Produktionspriserne udspringer af en udligning af varerværdierne, der - efter at de kapitalværdier, der er blevet opbrugt i de forskellige branchers (produktionsproces) er blevet reproduceret - fordeler den totale merværdi, ikke i den proportion hvori den er blevet produceret indenfor de enkelte brancher, og derfor er produkterne iboende, men i proportion med de fremskudte kapitalers størrelse. Kun således opstår en gennemsnitsprofit og en produktionspris for varerne, hvis karakteristiske element den er«. (Das Kapital, bd. III, s. 769. Min overs. OFK.)

Det er altså afgørende for gennemsnitsprofitratens og produktionsprisens begrebslige status, at de er tendensbegreber, ikke fast afgrænselige st ørrelser, men at de er afhængige af en udfoldelse i tiden, af en cyklus for at udfolde deres væsen.

Begrebet produktionspris betyder da simpelthen, at ved et givet produktivitetsniveau indenfor en branche vil en kapital med en lavere sammensætning

11. Jeg refererer her til den marxske akkumulationsteoris nøgletese: at den organiske kapitalsammensætning vil stige og profitraten derfor falde indenfor hver cyklus og formodentlig også på tværs af cykluserne. 
kunne realisere hele sin producerede merværdi. Men som branchens historie udvikles gennem en tilsivning af kapitaler og dermed den forøgelse af udbuddet, der ved at skærpe konkurrencen fjerner de mest lavproduktive kapitaler, så sænkes markedsværdiniveauet og dermed muligheden for realiseringen af hele den producerede merværdi for den omtalte kapital. Denne kapital har altså ved en given sammensætning og ved konstant merværdirate gennemgået en personlig livshistorie, hvori den startede med en høj profitrate - hvor profitten svarede til den producerede merværdi - og hvori den endte med knap at kunne realisere sin fremskudte kapital.

Samtidig er en række andre kapitaler opstået, med højere sammensætning, der realiserer ekstramerværdi mens markedsværdien endnu ikke er sunket så drastisk, d.v.s. mens branchen endnu ikke er blevet helt oversvømmet af kapital.

Denne udvikling passer til en branche med en traditionel lang historie, tekstilbranchen f.eks. Og pointen er at parallelt med det synkende markedsværdiniveau går dannelsen af den gennemsnitlige profit som de enkelte kapitaler $\mathrm{i}$ løbet af deres historie realiserer.

Men en anden type branchehistorie har de brancher, der er opstået med ny videnskab og teknik: brancher hvori der produceres elektronisk udstyr f.eks. Disse brancher er stofligt betingede for en meget høj kapitalsammensætning og indenfor disse vil markedsværdien - også selvom den reguleres af den lavest produktive kapital i branchen - ligge langt under niveauet i resten af samfundet. I denne branches livshistorie vil der kunne realiseres ekstraprofitter i forhold til den producerede profit (=merværdi), men her betragter vi forholdet mellem brancherne. Ekstraprofitten er altså her reguleret af det forhold, at den producerede profit er for lille til at give den profit som branchens kapitaler i forhold til kapitaler med samme sammensætning giver i andre brancher. Brancheproduktet vil altså her - for at salget kan give gennemsnitsprofitten - blive solgt til produktionspriser, der ligger langt over markedsværdiniveauet.

I næste afsnit skal vi præcisere ekstraprofittens 3 kilder, men her skal det principielle forhold belyses at hvor forskelle mellem profitterne på forskellige kapitaler indenfor en branche er hele konkurrencens dynamiske væsen, så gælder det, at kapitalbevægelsernes egen dynamik går i retning af at nivellere ekstraprofitter, der består på grundlag af produktivitetsforskelle mellem brancherne.

»Det er kapitalernes stadige tendens at bevirke udligningen i fordelingen af den af totalkapitalen producerede merværdi gennem konkurrencen og at overvinde alle hindringer for denne udligning. Det er derfor deres tendens kun at tolerere sådanne ekstraprofitter, som under alle omstandigheder, ikke p.g.a. forskellen mellem varernes vardier og produktionspriser, udspringer af den almene markedsregulerende produktionspris og de fra denne afvigende individuelle produktionspriser; (min fremhævelse, OFK.) (Marx taler her om det umulige i en profit indenfor industrisektoren, der som jordrenten ved »den absolutte jordrente « udspringer af en permanent lavere produktivitet indenfor landbrugssektoren, altså udspringer af det forhold, at markedsværdien indenfor landbrugssektoren permanent ligger over det produktionsniveau som konstituteres i industrisektoren. OFK.) ekstraprofitter, der derfor heller 
ikke finder sted mellem to forskellige brancher, men indenfor hver branche, og derfor ikke berører de almene produktionspriser mellem de forskellige brancher, altså ikke berører den almene profitrate og i stedet forudsætter forvandlingen af værdier til produktionspriser og den almene profitrate. Denne forudsætning beror dog, som tidligere belyst, på den stadige skiftende proportionelle fordeling af den samfundsmæssige totalkapital mellem de forskellige brancher, på stadig kapitaltil- og fragang, på deres (kapitalernes) overførbarhed fra en branche til en anden, kort og godt på den frie bevægelse mellem de forskellige brancher i egenskab af ligeså mange anlægssteder for den samfundsmæssige totalkapitals enkelte dele.« (Min overs. OFK. Das Kapital, bd. III, s. 769-770).

Skal det give mening, at ekstraprofitterne forudsatter dannelsen af produktionspriser, så refererer det til indførelsen af ens "produktionskoefficienter « i brancherne.

Denne proces er naturligvis begrænset af de stoflige muligheder for en ensartet produktionsproces, men hvor disse er nogenlunde givet betyder dannelsen af ens »produktionskoefficienter «, at forholdet mellem maskiner og arbejdere vil finde et generelt niveau bestemt af den herskende teknik og af arbejdskraftens uddannelsesgrad.

Teknikken betyder: bevægelses-, transmissions- og arbejdsmaskiner, hvor i alt fald bevægelsesmaskinerne i vid udstrækning udtrykker en normaliseret teknik: damp, diesel etc. Det betyder altså, at hver branche har en faktisk, real gennemsnitsproduktivitet bestemt af en mellemstor kapitalmasse ved en given organisk sammensætning. »Fast produktionskoefficient « betyder da,at man for at ændre den organiske sammensætning (denne indikerer direkte teknisk sammensætning, altså produktivitet) skal bevæge sig over i en helt anden »kapitalklasse«. Man kan altså ikke bare ansætte to ekstra arbejdere - for det kræver en ændring af hele maskinparken, og man kan ikke investere 100.000 til i maskiner, fordi en forøgelse af produktiviteten kræver et helt nyt system af arbejdsmaskiner. ${ }^{12}$

Det betyder også - det Marx her siger i citatet - at udbudefterspørgselsmekanismen vil være den samme for alle brancher over en cyklus, med forskellige udsving - naturligvis - på forskellige tidspunkter. De faste produktionskoefficienter og udbud-efterspørgsels-harmonien indebærer, at både repræsentationen af kapitalgrupper (inddelt efter organisk sammensætning) og deres antal vil være relativt ens i alle brancher over en cyklus - med den nedre og $\varnothing$ vre grænse for kapitalanlæg som produktionsprocessens stoflige særegenheder sætter.

I cyklusens $1 \varnothing b$ vil ekstraprofitterne og minusprofitterne i alle brancher altså tenderer mod at blive ensartede i den forstand at ingen branche i meget længere tid end de andre kan tilegne sig ekstraprofitter ved at have et højere markedsværdiniveau eller en større produktivitet end gennemsnittet.

Denne udligningsproces vil så - alt efter som produktivkræfterne udvikles i løbet af kapitalismen - gentage sig på højere og højere produktivitetsniveauer.

12. Se Jon Elster, der roder differentialrenterne sammen i sin underlige på engang formalistisk udskejende og sikkert problematiserende bog: Om Kapitalen, en introduktion til Marx' hovedværk, Oslo 1969, s. 71. Begrebet »produktionskoefficient« introduceres s. 69. 
Det her sagte betyder kun, at totalmerværdien bestemmer totalprofittens grænser over en cyklus, og at totalprissummen er reguleret af totalværdimassen.

Det betyder ikke at totalværdien produceret indenfor en branche i løbet af en cyklus med nødvendighed afgrænser den dér mulige prismasse og profitmasse. Men når Marx taler om dannelsen af produktionspriser, så mener han, at en branche, der p.g.a. sin overgennemsnitligt produktive kapital kan realisere ekstraprofitter mellem brancherne, at dens profitniveau vil nivelleres p.g.a. fald i efterspørgslen eller p.g.a. at resten af brancherne kommer op på samme produktivitetsniveau. Det betyder selvfølgelig ikke at der i denne branche - fordi der har været store ekstraprofitter - nu også må skabes et væld af minusprofitter, for at regnskabet skal stå lige. Det betyder bare at ekstraprofitterne ikke kan blive ved i det uendelige.

Skal vi anvende begreberne gennemsnitsprofitrate og produktionspris til at angive konkretere værdibevægelser, så hører følgende overvejelser med:

\subsection{Produktionspris, gennemsnitsprofitrate og markedsværdi som indi- katorer for værdibevægelser på det konkrete plan}

Den logiske eller metodologiske forudsætning for at tænke produktionsprisog gennemsnitsprofitrate-begreberne er dels begrebet »værdiproduktion«, dels markedsværdibegrebet: produktionspriserne og gennemsnitsprofitraten bliver mulige, alene fordi varerne kan realiseres til en anden værdi end den, der fremgår af den tid, der anvendtes ved deres produktion.

Omvendt er produktionsprisen den historiske betingelse for markedsværdiniveauet indenfor den enkelte branche. For det første er produktionspriserne princippet for kapitalbevægelserne mellem brancherne, for det andet er produktionspriserne $\mathrm{i}$ en række brancher vejledende for salgsprisen for kapitaler indenfor brancher hvis markedsværdier ligger under andre branchers eller for brancher, hvis individuelle værdier ligger langt over de andre branchers. Tager vi for eksempel en branche med en meget høj kapitalsammensætning, p.g.a. produktionsprocessens stoflige karakter, hertil en meget høj grænse for kapitalanlæg - altså alt i alt en meget produktiv branche - lad

os sige det er en branche hvori der produceres måleapparater til overlydsfly, så vil markedsværdiniveauet her ligge meget lavt, da merværdimassen ved konstant m' p.g.a. den relativt lille variable kapital vil være meget lille ${ }^{13}$. Det ændres heller ikke af det forhold, at efterspørgslen voldsomt overgår udbuddet - i alt fald ikke hvis vi antager, at markedsværdiniveauet i branchen ikke kan komme op over den grænse som den individuelle værdi af den mindst produktive kapital sætter.

13. Das Kapital, bd. III, s. 767. 
Jeg vil her lige gentage, at hvor markedsværdien udgør et prisniveau indenfor en branche, der er dækket ind af den faktiske værdiproduktion i branchen, så ligger det i produktionsprisens væsen, at den afviger fra markedsværdierne.

De grænser, der er sat for markedsværdien - at den altså hvis den i længere tid skal konstitueres af den mindst produktive kapital, i en anden periode af cyklusen må presses så meget ned at værdiunderskuddet opvejes, hvilket er en naturlig følge af den kapitaloverflod i branchen som et højt markedsværdiniveau skaber - gælder ikke for produktionsprisen: i den omtalte branche vil salgsprisen ligge over markedsværdien - der repræsenterer den højeste individuelle værdi og den vil ligge så meget over, at gennemsnitsprofitten danner bundgrænsen for salgsprisen. Denne konstitueres altså af varens produktionspris.

Det kan være problematisk at hæfte så konkret et indhold på et så tendensbestemt og »agerende « begreb som produktionsprisen, men det er rimeligt at gøre det i netop denne forbindelse, samt i een til, som vi skal se i det følgende.

Produktionsprisens »realitet « viser sig her i det forhold, at det er den, som kapitalerne lægger deres prisniveau efter indenfor sådanne højproduktive brancher, det er nemlig den, der fortæller dem, hvad de kan vente sig af et givet kapitalanlæg, dvs. hvor stor en profit de kan lægge oveni omkostningsprisen, og hvor store negative udsving de kan bære over med i deres profitrate uden at flytte deres kapital. Hvis produktionsprisen her skal konkretiseres - og med den gennemsnitsprofitraten - stiller det et logisk problem: hvilke brancher er de oprindelige produktionsprisangivende?

Historisk set løser problemet sig selv ved at visse brancher har været de første for kapitalanlæg og har været meget profitable, brancher som tekstil, jernbaner ect., men logisk set er problemet tilbage.

P. Sraffa berører problemet i sin indledning til udgaven af Ricardos samlede skrifter, når han siger, at Ricardos indledende berøring med værdibegrebet udgik fra den tese, at »it is the profit of the farmer, that regulate the profits of all other trades $\ll .{ }^{14}$

Ifølge Sraffa skyldes denne tese et argument, der kan rekonstrueres, og som går ud på, at det i landbrugssektoren er den samme vare, der fungerer som kapitalen og produktet, dvs. at profitten kan bestemmes udelukkende i brugsværditermer når den reproduktive kornmasse trækkes fra produktet. I alle andre brancher indgår andre produkter i kapitalen og der findes derfor ikke noget »naturgivent « profitniveau.

Men det er klart, at for Marx - der inddrager landbrugssektoren som en integreret del af den kapitalistiske økonomi - kan profitniveauet i landbrugssektoren ikke blot ikke sættes logisk $f \phi r$ profitniveauet i industrien, men er selv konstitueret af dette via betingelserne for dannelsen af »den absolutte jordrente«. (se

14. Sraffas indledning til The Works and Correspondence of David Ricardo, Cambridge 1970, bd. 1 . 
fremme). For Marx vil en sådan abstraktion forblive historieløs tilsnigelse, der ikke begriber, at betingelsen for produktionen er kapitalens bevægelser.

Forskellen mellem brancheproduktets individuelle værdi, den værdi, der optimalt kan realiseres gennem den i branchen producerede værdi og så produktionsprisen (eller en pris der ligger derover) kalder Marx for ekstraprofitten. I modsætning til ekstramerværdien, der alene kan realiseres indenfor en branche hører ekstraprofitten til i forholdet mellem brancherne.

Vi støder her igen på begrebernes dobbelte karakter her på niveauet-forkapitalen-i-dens-realitet: de er både begreber, der kun udtrykker en tendens, resultatet i gennemsnit af kapitalers livsforløb, og de er begreber, der i visse situationer, kan antyde en sammenhæng, der udgør et snit gennem tiden:

Tendensmæssigt gælder følgende: markedsværdien må som resultat af prisbevægelserne indenfor en cyklus i almindelighed være forløbet indenfor de rammer som den producerede totalværdi i branchen sætter. Markedsværdien er her et grænsebegreb, der angiver hvor meget profit arbejdet ifølge sin absolutte produktivitet kan høste, mens ekstraprofitten angiver hvor meget det ifølge sin relative produktivitet har fået. Produktionsprisen gør realiseringen af den relative produktivitets frugter mulige. Ekstraprofitten er her et begreb, der angiver, at branchen ifølge sin produktivitet adskiller sig fra samfundets gennemsnitsbetingelser, men ifølge sine kapitalers væsen præcis lever op til disse gennemsnitsbetingelser: at afkaste en given profitrate. Generelt må kapitalernes bevægelse mellem brancherne dog medføre, at kapitalerne i den branche, der i begyndelsen realiserer enorme ekstraprofitter ved at varerne sælges over produktionsprisen, langsomt - gennem kapitaltilsivning - ser prisniveauet synke, først til produktionsprisniveau, så til et markedsværdiniveau, der sættes af den mindst produktive kapital og endelig til markedsværdiniveau, der måske sættes af de mest produktive kapitaler, hvilket betyder produktion med tab for resten af branchen.

Ekstraprofitten er altså ikke et permanent fænomen, men vil ifølge kapitalens og dermed konkurrencens væsen udlignes. I et givet udsnit i tiden af forholdet mellem brancherne vil ekstraprofitten gennem sin eksistens belyse den anarkiske fordeling af teknik og videnskab i produktionen, belyse kapitalismens irrationalitet med henblik på en output-effektiv organisering af produktionen, og belyse visse branchers rolle (politiske) og situationen i total reproduktionen, belyse udbud-efterspørgslens forl $\varnothing b$, og belyse arbejderklassens underkastelse under kapitalens behov.

Der er 3 fundamentale former for ekstraprofit, der hver især har et forskelligt forhold til værditeorien:

I) Den kan som i dette eksempel være forskellen mellem den producerede gennemsnitligt alt for lave - profit i en højproduktiv branche og så den profit, der ved salg til produktionsprisen svarer til gennemsnitsprofitraten eller ved salg til en højere pris til en profit, der ligger derover. I dette tilfælde er 
markedsværdien ikke nogen real størrelse, men så at sige brancheproduktets individuelle værdi.

II) Ekstraprofitten kan være forskellen mellem produktionsprisen i f.eks. industrisektoren og så produktværdien i landbrugssektoren, hvor den sidste p.g.a. lavere organisk sammensætning ligger over produktionsprisen i industrisektoren, og p.g.a. efterspørgslens pres sammen med monopolet på jord og skrankerne for kapitaltilførsel kan sælges til en højere værdi end produkterne $\mathrm{i}$ industrien.

Denne ekstraprofit, der altså udspringer af landbrugets manglende produktivitet, og som er den rest, der er tilbage, når landbrugsproduktets omkostningspris + gennemsnitsprofitten er trukket fra, kalder Marx for $\gg$ den absolutte jordrente $\ll$.

III) Endelig kan ekstraprofitten bestå af den ekstra værdimasse, der realiseres, hvis produktiviteten indenfor en branche er så lav at efterspørgslen overstiger udbuddet permanent og intenst, således at den mindst produktive kapitals produktværdi regulerer markedsværdien.

Dette tilfælde er det Marx forstår ved den systematiske årsag til differentialrenterne indenfor landbrugssektoren. (Das Kapital, bd. III, s. 654).

Det sidste tilfælde betegner Marx alene som et tilfælde, hvori der »skabes« »falsk social værdi«. Marx viser s. 673, i bd. III af Das Kapital, hvordan der gennem differentialrenterne kan realiseres en næsten 3 gange så stor værdi som der skabes indenfor sektoren, og siger så:

»Dette er bestemmelsen gennem markedsværdien, således som den på basis af den kapitalistiske produktionsmåde sætter sig igennem via konkurrencen; denne skaber en falsk social værdi «. (Min overs. OFK.)

I de to første tilfælde er der naturligvis også tale om skabelse af en form for »falsk social værdi $\ll$.

Kernen i dette begreb består altså i, at der indenfor en branche enten realiseres mere værdi end der skabes over et givet forløb (cyklus), tilfælde I og III, eller produceres og realiseres mere værdi end der burde, hvis branchen gennem sin cyklus faktisk integreredes i dannelsen af produktionspriserne og gennemsnitsprofitraten.

Perspektivet $\mathrm{i}$ brugen af begrebet »falsk social værdi« ligger bl.a. i en påvisning af, hvordan kapitalismen spilder det samfundsmæssige arbejde sammenlignet med hvordan en socialistisk organisering af produktionen ville fordele arbejdet. Dette perspektiv følger eksplicit i passagen, der kommer umiddelbart efter at Marx har defineret begrebet »falsk social værdi «. Fortsætter vi ovennævnte citat hedder det:

»Denne (»den falske sociale værdi«, OFK.) udspringer af markedsværdiens lovmæssighed, som agerbrugsprodukterne er underkastet. Bestemmelsen af produkternes markedsværdi, altså også af agerbrugsprodukternes, er en samfundsmæssig proces, selvom det er en samfundsmæssig ubevidst og ikke-intenderet fuldført (handling, OFK.), der med nødvendighed er betinget af bytteværdien hos produktet, ikke af jorden og forskellene i dennes frugtbarhed. Tænker man sig den kapitalistiske form for samfund opløst og samfundet organiseret som bevidst og planmæssig samvirken, så ville de 10 quarters udtrykke et kvantum selvstændig arbejdstid, lig det, der er indeholdt i de 240 
shilling, (i stedet solgtes produktet til 600 shilling, dvs. der var i kapitalismen indeholdt 360 shilling »falsk social værdi i i det. OFK.) Samfundet ville altså ikke købe dette agerbrugsprodukt for $2 \frac{1 / 2}{2}$ gange så meget som den virkelige arbejdstid, der er udgivet på det; jordejerklassen ville da falde væk som basis (for produktionen. OFK.) Dette ville virke præcis lige sådan som en billiggørelse af produktet med samme beløb p.g.a. import. Så sandt som det er at sige, at såfremt produktionsmåden ikke forandres, men det forudsættes, at differentialrenten tilfalder staten - agerbrugsprodukternes priser ved ellers uforandrede omstændigheder ville forblive de samme, lige så forkert er det at sige, at produkternes værdi ville forblive den samme, hvis den kapitalistiske produktion afløstes af producenternes frie samvirke. Ensartetheden hos markedsprisen på varer af samme art er den måde, hvorpå vardiens samfundsmassige karakter satter sig igennem på basis af den kapitalistiske produktion og overhovedet på basis af en produktion, der hviler på varebytte mellem enkeltpersoner. Hvad samfundet som konsument betragtet betaler for meget for agerbrugsprodukterne, hvad der udgør et minus for realiseringen af dets arbejdstid i agerbrugsprodukter, udgør nu et plus for en del af samfundet, for jordbesidderne«. (Das Kapital, bd. III, s. 674. Min overs. og fremhævelse. OFK.)

»Den falske sociale værdi« er altså et produkt af det forhold, at kapitalen af al magt vil maximere sin profit, og af at visse sociale forhold - eksistensen af monopol på jord og befolkningseksplosionen - gør et permanent højt markedsværdiniveau nødvendigt og muligt.

Marx's begreb »absolut jordrente« - der udvikles i polemik mod Ricardos jordrentebegreb - går ud på, at monopolet på jord skaber institutionelle betingelser for en blokering af udbuddet af landbrugsprodukter, nemlig ved at blokere inddragelsen af mindre frugtbare jorde til kornavl. Blokeringen foregår, fordi jordene kun kan dyrkes, hvis der betales en leje for dem, og denne leje er netop jordrenten. Følgelig vil der kun blive anlagt kapitaler på de jorde, der ved salget af deres produkter giver både jordrenten og en profit svarende til, hvad man ville kunne få ved anlæg af samme kapital i industrisektoren. Kun jorde inddrages altså, der gør et så lavt omkostningsniveau muligt, at både gennemsnitsprofit og jordrente kan realiseres gennem salget af produktet.

Det ligger i kapitalens væsen, at den kun tolererer ekstraprofitter indenfor brancherne, ikke mellem dem, dvs. at hele konkurrencens bevægelse går mod en reduktion af de mellem-branchemæssige ekstraprofitter, som naturligvis hele tiden realiseres. Derfor vil kapitalen sive til den branche, hvor ekstraprofitterne i forhold til resten af samfundet et størst (de stofligt bestemte kapitalanlægsgrænser spiller naturligvis ind her), eller hvor der realiseres en gennemsnitsprofit ved lavere sammensætning end i resten af samfundet (disse to tilfælde er naturligvis helt forskellige).

Kun hvor denne kapitalbevægelse ikke er institutionelt mulig - som i landbruget i England på Marx’s tid og især før ophævelsen af The Corn Laws - vil de høje markedsværdier og dermed ekstraprofitterne kunne være permanente.

Dannelsen af produktionspriser og gennemsnitsprofitrate er helt afhængig af udeblivelsen af sådanne institutionelle skranker:

»Det er her forudsat at ingen eller højst en kortvarig eller tilfældig skranke forhindrer kapitalernes konkurrence - f.eks. i en branche, hvor vareværdierne står over deres produktionspris eller hvor den producerede merværdi ligger over gennemsnitsprofitten - $i$ at reducere værdien til produkti- 
onsprisen og dermed fordele den overskydende merværdi fra denne branche proportionelt mellem alle de brancher, som kapitalen har udbyttet. Hænder derimod det modsatte, støder kapitalen på en fremmed magt som den kun delvis eller slet ikke kan overvinde, og som begrænser dens anlæg indenfor visse brancher, altså kun tillader dem under betingelser, der udelukker den almene udligning af merværdien til gennemsnitsprofit helt eller delvis, så ville der åbenbart opstå en ekstraprofit i sådanne brancher p.g.a. den overskydende rest hos vareværdien over dens produktionspris, der ville blive forvandlet til rente således selvstændiggjort overfor profitten. Som en sådan fremmed magt og skranke fremstår jordejendommen for kapitalen ved dens anlæg i bygge- og landbrugsjord eller fremstår jordbesidderen for kapitalisten«. (Das Kapital, s. 770, min overs. OFK.)

I Marx' begreb »den absolutte jordrente « ligger den grundforudsætning, at de realiserede ekstraprofitter også er produceret. Der er ikke tale om et forhold mellem kapitaler indenfor denne branche - det er derimod Ricardos eneste perspektiv på jordrenteproblematikken. Bringes forholdet mellem kapitaler indenfor landbrugssektoren derimod ind, - og det gør det i begrebet »differentialrente« - så bæres ekstraprofitterne ikke længere af produceret værdi.

$»$ Absolut rente er vardiens overskud over råproduktets produktionspris. Differentialrente er markedsprisens overskud hos de produkter, der er dyrket på gode jorde, over deres egen produktvardi «. (Theorien über den Mehrwert, bd. II, s. 138. Marx's fremhævelser, min oversættelse. OFK. $)^{15}$

Denne situation, - der i industrien aldrig vil kunne være permanent, dels fordi der dér ikke hersker nogen institutionel skranke for kapital, dels fordi produktiviteten kan forøges absolut, dvs. at der ingen naturmæssigt givne begrænsninger er for produktivitetsudviklingen (som i landbruget), - kan kun være permanent i helt særlige tilfælde.

Selv en højproduktiv branche med stoflige grænser for højt værdiindhold i produkterne kan ikke vedblive med at realisere ekstraprofitter, fordi dens teknik vil blive billigere, større kapitaler vil trænge ind og forøge udbuddet og mindre kapitaler på baggrund af de billigere produktionsmidler hæve markedsværdiniveauet, (så branchen ikke »tager værdi« fra de andre ved dannelsen af sine produktionspriser).

Kun hvor særlige forhold skaber en naturgiven disharmoni i udbudefterspørgsels-mekanismen, så udbuddet aldrig kan besvare efterspørgslen fuldt ud, kan markedsværdier regulere prisniveauet, der indebærer, at profitterne realiseret i branchen permanent ligger over gennemsnittet i samfundet. Dette er sikkert tilfældet i olieindustrien.

Det er nu min tese i denne artikel, at staten gennem sin politisk betingede efterspørgsel på boliger, erhvervsvirksomheder og andre varer fra bygge- og anlægssektoren vil gøre skabelsen af »falsk social værdi« mulig dér. Dette skyldes at den intense og permanente efterspørgsel skaber et markedsværdiniveau i denne sektor, der ligger højere end i resten af samfundet. De mindst

15. Dette citat har Marx skrevet på engelsk. Begrebet »Durchschnittspreis« (average price) oversættes her - tro mod den generelle betydning i bd. II af Theorien über den Mehrwert - med begrebet »produktionspris«. 
produktive, altså mest arbejdsintensive virksomheder kan altså regulere markedsværdiniveauet i denne branche og dermed sikre en ekstraprofit til alle andre kapitaler. Naturligvis kan dette markedsværdiniveau kun være permanent så længe de politiske beslutninger sikrer efterspørgslen og dermed holder denne sektor ude af den reproduktionscirkel, der reguleres af kræfternes frie spil, dvs. af prisstigninger og -fald som følge af kapitalbevægelser til og fra branchen (sektoren).

Som nævnt er det ikke uproblematisk at lade de forhold, der er opremsede for en sektor som landbrugssektoren med henblik på kornproduktion gælde for en sektor som bygge-anlægs. Thi hvor produktet kvalitativt og kvantitativt er ensartet i landbrugssektoren (det er nemlig korn), så er bygge-, anlægssektorens produkter vidt forskellige. Det betyder at der ikke dannes en konkret enhedspris, fordi der går forskellig mængde konstant og variabel kapital, fix og cirkulerende kapital ind i henholdsvis produktionen af et egeparket og af en wc-kumme.

Alligevel kan Marx's begreb »falsk social værdi«, der refererer til et ensartet brancheprodukt og dermed til en enhedspris i bogstavelig forstand, accepteres her, fordi produkterne i bygge-, anlægssektoren indgår omtrent identisk i reproduktionen: de har næsten ens funktion i den produktive og private konsumtion - med undtagelse af visse udprægede luksusartikler. Branchelovene kan her anvendes således, at sektoren ikke skal producere den værdi den realiserer i et snit gennem tiden, over et år f.eks., men nok over en hel cykel eller i alt fald tendere imod det. Samtidig gælder, at det nu er de lavest sammensatte branchers markedspriser, der regulerer profitniveauet, ved at foreskrive et profitniveau. Ved konstant m' vil disse kapitaler naturligvis have den største merværdimasse, og da de altså realiserer den hele kan de eksemplarisk foreskrive resten af sektoren samme profitniveau som minimal granse. Dette kan lade sig gøre, fordi efterspørgslen på disse - af stoflige årsager bl.a. arbejdsintensive kapitaler - er så permanent at selv kapitaltilførsel til disse brancheprodukters produktion ikke sanker markedsvardiniveauet. Det permanente eftersp $\phi$ rgselsoverskud på denne sektor g $\phi r$ altså, at den samme profit kan realiseres ved at anlogges $i$ et andet brancheprodukt indenfor sektoren. Således afbødes virkningerne på produktionspriserne og på markedsvardierne af den - p.g.a. det »permanent « høje profitniveau - accellerende kapitaltilførsel.

Et andet moment, der uden egentlige institutionelle skranker for kapitaltilførsel - såsom monopol på jord - alligevel kan forhale ekstraprofitniveauets fald er visse brancheprodukters krav om meget høj kapitalanlægsgrænse og muligheden for at anlægge profitabel kapital i meget små og arbejdsintensive håndværksfirmaer. Dette gælder også - som vi skal se - for bygge-, anlægssektorens to hovedleverandør-brancher (brancheklynger): sten-, ler- og glasindustri og træ- og møbelindusri. Også hos dem kan ekstraprofitterne opretholdes i længere tid end det har været tilfældet i de $\varnothing$ vrige brancher.

Pointen her er altså, at en situation, der af resultat ligner den, der avlede differentialrenterne, er mulig ved et så stort efterspørgselspres, at kapitalbevæ- 
gelserne ikke i sædvanlig grad kan udligne pris- og profitniveauet gennem en forøgelse af udbuddet, (at dette også har stoflige årsager ser vi af bygge-, anlægssektorens små og arbejdsintensive virksomhedstyper, der bl.a. har reperation som arbejdsindhold, en funktion, der er svær at forbinde med en voldsom accelleration af produktionsmidlerne).

Selvom årsagerne til de permanente ekstraprofitter her altså ikke er de samme som i landbrugssektoren før og delvis efter ophævelse af The Corn Laws i 1848, så er deres virkninger i vid udstrækning de samme hvad angår totalreproduktionen.

Disse virkninger er følgende:

a) Blokering af dannelsen af gennemsnitsprofitraten og produktionspriserne i samfundet, dvs. ulige produktivitetsudvikling og derfor blokeringer i reproduktionsprocessen eventuelt gennem varemangel, der så giver sig udtryk i betalingsbalanceforværringer p.g.a. den forøgede import, ect.

b) Fald i reallønnen for nogle lønmodtagergrupper p.g.a. fordyrelse af f.eks. boligudgifterne og dermed et yderligere lønpres. Dette lønpres i forening med det lønpres, som den stigende progressive beskatning til forøgelse af de offentlige udgifter til køb hos sektoren giver, skaber valoriseringsvanskeligheder for kapitalen p.g.a. stigninger i den variable kapital. (Yderligere vanskeligheder kan skabes gennem boligfordyrelsens påvirkning af forbrugsmønsteret. $)^{16}$

Dette virker igen ind på akkumulationsmønsteret idet tendensen til at forøge produktionen gennem en udvidelse af den konstante kapital på bekostning af den variable accentueres.

Ricardo formulerer helt klart denne katastrofale virkning på den kapitalistiske $\varnothing$ konomi af manglende koordinering med produktivitetsudviklingen i resten af samfundet hos den sektor i samfundet, hvis produkt indgår som hovedbestanddel i arbejdskraftens værdi.

»Med enhver stigning i (total)-kapitalen og befolkningen vil fødevarerne almindeligvis stige, da de vil være vanskeligere at producere. (Ifølge loven om differentialrenterne. OFK.) Konsekvensen af en stigning i fødevarerne vil være en stigning i lønningerne, og enhver stigning i lønningerne vil have en tendens til at lede den opsparede kapital hen til investering i (konstant) kapital i en proportion større end det tidligere var tilfældet. Maskineri og arbejdskraft befinder sig i permanent indbyrdes konkurrence, og den første (type kapital) anvendes ikke før arbejdets (arbejdskraftens) værdi stiger.« (Principles of Political Economy and Taxation. Everymanudgaven. s. 270, Min overs. og paranteserne er indføjet af mig. OFK.)

c) Valoriseringsbesvær som følge af kapitalbeskatningen og fordyrelsen af konstant kapital af typen »erhvervsbyggeri«, ect.

16. Olav Grue: Byggevirksomheden og den $\varnothing$ konomisk uvikling, Studier fra Københavns Universitets Økonomiske Institut, nr. 12, København 1967. kap. 8. 
d) Vanskeligheder for nationalkapitalen på verdensmarkedet p.g.a. det høje nationale prisniveau. Valutarisk usikkerhed, ect.

e) Betalingsbalancebesvær p.g.a. de offentlige lån i udlandet til at financiere den offentlige sektor med.

(Yderligere resultater og disses systematiske bestemmelse er emnet for del II.)

Man må nu stille det spørgsmål i forbindelse med min bestemmelse af skabelsen af »falsk social værdi« som det knudepunkt hvorudfra statsinterventionen skal forstås: hvorfor kan problemet ikke udelukkende løses således, at inflationsvirkningen af det udsædvanligt høje prisniveau i visse sektorer eller brancher eller brancheklynger forklares ud fra det forhold, at der simpelthen produceres mere vardi dér?

Her gælder det, at kapitalintensiteten og kapitalbevægelserne gør denne løsning både empirisk og logisk uacceptabel. Empirisk set er den ikke rimelig fordi kapitalsammensætningen er $h ø j \mathrm{i}$ denne sektor indenfor en række firmaer og fordi kapitalen er stor i forhold til andre brancher og sektorer. Logisk kommer den i konflikt med tesen om princippet for dannelsen af gennemsnitsprofitraten og produktionspriserne: at der vil sive store kapitaler ind i en sektor med så lav en sammensætning og så højt et markedsniveau og så stor en efterspørgsel og dermed vil produktiviteten stige.

Man må nemlig gøre sig klart, at et højt markedsværdiniveau indenfor en sektor ikke behøver betyde at kapitalsammensatningen dér er lav. Derimod viser det, at efterspørgslen overgår udbuddet og at stoflige og politiske forhold $\mathrm{g} \varnothing \mathrm{r}$ denne efterspørgsel permanent og blokerer for at den besvares gennem en adækvat forøgelse af udbuddet.

At der findes mange arbejdsintensive virksomheder i bygge-, anlægssektoren p.g.a. arbejdets håndværksmæssige organisering og reperationsarbejdets andel af totalarbejdet betyder ikke, at produktiviteten generelt er lav i denne sektor og at ekstraprofitten derfor også er produceret, at der altså er tale om præcis den samme situation som ved »den absolutte jordrente «. At efterspørgslen permanent overgår udbuddet i boligsektoren skyldes at denne efterspørgsel nødvendigvis må blive en efterspørgsel på nye boliger, fordi efterspørgslen på ældre boliger er helt overeksponeret p.g.a. huslejepolitikken. ${ }^{17}$

De ekstraprofitter, der realiseres på nybyggeri og som giver en »overnormal forrentning af den investerede kapital ${ }^{18}$, er ikke resultat af en lav sammensætning af denne kapital - den er meget høj i forhold til den kapital, der anvendtes ved tidligere boligbyggeri, og den ligger på linie med sammensætningen i kapitalen andre steder i samfundet. (At differentialrentebegrebet kan anvendes i forbindelse med byggeriet er indlysende - som jeg også skal uddybe i næste afsnit).

17. Grue, ibd. s. 159.

18. Grue, ibd. s. 157. 
Loven om produktionspris- og gennemsnitsprofitratedannelsen, der er den mest funktionskraftige lov i hele Marx's teori om kapitalismen, indebærer altså, at en forklaring gennem værdiproduktion af de nævnte forhold kun er mulig i en situation, hvor der er tale om en monopolsituation og om naturgivne blokeringer for produktivitetsudviklingen. En situation der hører til i landbruget i det 19-nde århundrede og ikke i bygge-, anlægssektoren i det 20-nde.

Derimod kan påpegningen af en arbejdsintensiv kapital i denne sektor og den lave organiske sammensætning i en række små virksomheder være et delmoment af en forklaring, men aldrig andet. Loven for dannelsen af produktionspriserne og gennemsnitsprofitraten, der indebærer $\emptyset$ get kapitaltilførsel til en sektor med et højt markedsværdiniveau, medfører, at et permanent markedsværdiniveau i skyerne aldrig kan være resultatet af reelt brancheproduceret værdi, men må være resultatet af en forskydning mellem produceret og realiseret værdi som det ligger i begrebet »falsk social værdi «.

Vort perspektiv på forholdet mellem stat og kapitalistisk samfund i en given historisk fase af dettes udvikling, hvor statsfunktionerne påvises at måtte justeres til lovmæssighederne for dannelsen af gennemsnitsprofitraten og produktionspriserne indebærer også, at en mere konkret tilgang til begreberne produktionspris og gennemsnitsprofitrate er nødvendig.

Denne kan kun gives når man i sin talen om »falsk social værdi indenfor en sektor har et konkret niveau at udgå fra, et niveau, der kvantitativt afgrænser indholdet af begrebet »falsk social værdi « på totalsamfundsmæssigt plan. Dette niveau er niveauet for profitraten i enkelte af de dominerende brancher i industrien, her i de virksomheder givetvis, der producerer arbejdsmaskiner til hele industrien.

Marx viser tydeligt selv at dette er nødvendigt, for uden et kendskab til gennemsnitsprofitraten i industrisektoren (eller enkelte af dens brancher, hvor produktivitetsniveauet er udlignet) kan begrebet produktionspris i industrien ikke udvikles, og begrebet »absolut jordrente « bliver da meningsløst, fordi der ikke er noget niveau jordejeren og forpagteren kan tage som udgangspunkt for deres pagt. Thi pagtens kerne indebærer, at kun de jorde vil blive forpagtet, (af en kapitalist), der er så produktive, at salget af deres produkter kan give både gennemsnitsprofitraten og jordrenten i dennes laveste rate. Dvs. kun hvor kapitalerne kan være så arbejdsintensive (stor » $\mathrm{V}$ «), at det kan give en merværdi, der indeholder både gennemsnitsprofitraten og renten, er forpagtningen mulig.

Men for at kapitalisten kan vide om han skal forpagte en given type jord eller ej og for at jordejeren skal vide om han kan leje den ud, så må kapitalisten vide hvor meget profit han kan forvente og jordejeren vide hvor meget rente han kan kræve. Altså må man antage at forventningen har en realitet at hente sit forventede fra, og det kan kun være et accepteret, som erfaringsfaktum oplevet profitniveau.

Dette skaber dog ikke overvældende problemer, fordi gennemsnitsprofitraten i industrisektoren blot kan opfattes som den profit, der realiseres på de 
gennemsnitsligt sammensatte og branchedominerende kapitaler i de vigtigste brancher af SI (produktionsmiddelsektoren). Altså at to eller flere brancher i industrien indenfor en kortere periode giver samme afkast på ens sammensatte kapitaler. (Dette betyder ikke nødvendigvis at disse kapitaler er absolut lige store, men de vil givetvis også være en tendens i denne retning).

Her hører Marx's udsagn om, at gennemsnitsrentefoden (her er tale om rente af kapital, ikke om jordrente) følger gennemsnitsprofitraten i store træk, for rentefoden er selvfølgelig - foruden en minimalprofit - bundgrænsen for et forventet kapitalafkast, hjemme. ${ }^{19}$

Der er altså logisk set hjemmel nok i Marx's arbejder for at søge indikatorer af konkretere art for gennemsnitsprofitraten og produktionspriserne. Marx opfatter da også selv i Theorien über den Mehrwert prisindekser for landbrugsprisernes bevægelser som tal, hvoraf man direkte kan aflæse produktionspriserne. ${ }^{20}$

\subsection{Afsluttende opsummering af begrebernes indhold:}

Lad mig afslutte dette teoretiske afsnit med at præcisere forholdet mellem det dynamiske og statiske indhold af begreberne »markedsværdi« på den ene side og »gennemsnitsprofitrate « og »produktionspris« på den anden side:

Om markedsværdien gælder altså følgende:

\section{A) Dynamisk indhold:}

Her er dens indhold, at den prissum, der realiseres indenfor en branche indenfor en cyklus vil være dækket ind af summen af de individuelle værdier produceret dér. Markedsværdien udgør altså et aritmetrisk gennemsnit af produktivitetsniveauer indenfor branchen gennem cyklusen. Det betyder selvfølgelig ikke at markedsværdien statisk set er identisk med det aritmetriske gennemsnit af de individuelle værdier produceret indenfor branchen i et kortere tidsrum, men derimod at dens værdiindhold hopper op og ned omkring dette ideelle, konstruerede gennemsnit, og må hoppe ned, hvis den har stukket hovedet for langt op og omvendt.

Det betyder, at man - naturligivs med en række modifikationer så som den forudsætning at guldfoden er konstant eller at valutaen er det, ect. - kan tage prisstørrelser som direkte indikatorer på værdibevægelser.

19. Das Kapital, bd. III, s. 377-378.

20. Theorien über den Mehrwert, bd. II, s. $127 \mathrm{ff}$. Marx taler om »Durchschnittspreise«, men s. 123 defineres disse som »produktionspriser«, og når han s. 203 i bd. II af Theorien über den Mehtwert siger: »Den virkelige markedspris står snart over snart under denne markedsværdi og er kun tilfældigt identisk med den. Men over en vis periode udlignes udsvingene, og man kan sige, at gennemsnittet af de virkelige markedspriser er den markedspris, der udtrykker markedsvaerdien. «(Min overs. Marx' fremhævelser. OFK.) opfatter han altså gennemsnitspriser som $=$ markedsværdien . 
Markedsværdien som tendens indebærer ifølge sit væsen, at der indenfor en branche vil dannes et ensartet teknisk niveau hos en stor del af firmaerne. Dermed vil disse firmaer producere og realisere en gennemsnitsprofit alt afhængig af branchens placering i totalreproduktionen, dvs. om dens stoflige forudsætninger giver den en for lav eller for høj sammensætning i samfundsmæssig målestok.

Endelig er »markedsværdien« som begreb - hvad enten det udtrykker en tendens eller noget statisk - udtryk for det forhold, at der er en essentiel forskel mellem relativ merværdi og ekstramerværdi. Ekstramerværdien kan aldrig forklares ud fra en given kapitals værdiproduktion, men må forklares ud fra en systematisk forskel mellem værdiproduktion og værdirealisering. Forklarer man derimod ekstramerværdien eller ekstraprofitten ud fra en kapitals værdiproduktion, så subjektiviserer man værditeorien, man reproducerer altså Böhm-Bawerks ${ }^{21}$ indvendinger netop mod Marx's endegyldige bestemmelse af prisbevægelserne i konkurrencen ud fra værdien som objektiv værdi.

Identificerer man relativ merværdi og ekstramerværdi siger man altså, at alle prisbevægelser bestemmes af efterspørgslen - og så forlader man værditeorien eller indfører et begreb for yderligere værdiproduktion som det ligger i begrebet »kompliceret arbejde« og som Ole Marquardt ${ }^{22}$ så glimrende har jævnet med jorden, såfremt det tolkes som et begreb der angår værdiproduktionen.

Eller også begår man den fejl som hele Marx's tænkning er rettet mod at tilintetgøre: forestillingen om produktionsmidlernes værdiskabende evne. Man reproducerer altså den »trinitariske formels illusioner « og hævder - om man vil det eller ej - at årsagen til at nogle kapitaler kan realisere en ekstraprofit skyldes at de producerer den. Og da det ligger i hele akkumulations-perspektivets essens, at produktivitetsudvidelse $i$ princippet foregår gennem udvidelse af den konstante kapital på den variables bekostning, så kan det altså kun være produktionsmidlerne, der »producerer « den omtalte ekstramerværdi, da merværdiraten forudsættes konstant. At merværdiraten ikke kan optræde som forklaringsinstans her kan fastlægges ud fra det forhold, at dens stigning skal være lidt højere end omvendt proportional med det absolutte fald i den variable kapital - et forhold, der næppe er empirisk generelt, dvs. er type-forholdet mellem $\mathrm{k}$ og $\mathrm{v}$ i akkumulationsbevægelsen. Og det kan fastlægges, fordi merværdiraten slet ikke er noget begreb, der angår enkeltkapitalen i det øjeblik vi har en konstant arbejdsdag, en nogenlunde fast mindsteløn og stramme normer for overarbejde. Merværdiraten angår da blot produktivitetsforholdet i sektor II (konsumtionsmiddelsektoren), og den konstante merværdirate som er Marx’s præmisse ved enhver behandling af kon-

21. Böhm-Bawerk: Zum Abschluss des Marxschen Systems, trykt i Aspekte der Marxschen Theorie 1, Zur Methodischen Bedeutung des 3. Bandens des »kapital«, udg. af F. Eberle, Suhrkamp, 1973.

22. Ole Marquardt: En kommentar til den såkaldte reduktionsproblematik og dennes betydning for den marxske arbejdsværditeori. Fagtryk, februar 1975. 
kurrencens begreb, er da både empirisk indløst $o g$ logisk nødvendig af hensyn til ikke at blande relativ merværdi og ekstramerværdi sammen, da forestillingen om at ekstraprofitten er produceret er bundet til troen på at merværdiraten er forøget hos en række individuelle kapitaler.

At Marx i begyndelsen af Theorien über den Mehrwert bd. II selv gennem sin udvikling af differentialrentebegrebet på baggrund af Ricardos geniale indsigter laver den omtalte fejl og tager fat med at begrunde ekstraprofitten i landbruget på de frugtbareste jorde og på de jorde med mest anlagt kapital ud fra en produceret værdi, sætter netop denne fejltagelse i perspektiv, fordi han omkring s. 100 selv bryder med den og implicit begynder at operere med begrebet »falsk social værdi«. Fejltagelsen indebærer Ricardos vage forestillinger, der synes at indikere, at differentialrenterne er dækket værdimæssigt ind. Selvom der i Ricardos begreb »relative value « ligger indhold, der kan synes at befri ham fra den omtalte fejltagelse - som den Marx, der har erkendt begrebet »falsk social værdi«, nu netop kan beskylde ham for: nemlig for ikke at have $»$ udviklet og begrebet ... forskellen mellem produktionspriser (Marx kalder her sin vane tro "produktionspris« for »Kostpreis«, OFK.) og værdi...« selv om han dog »faktisk har konstateret den.« (Theorien über den Mehrwert, bd. II, s. 196. Min overs. OFK.)

\section{B) Statisk indhold}

Statisk set er markedsværdien udtryk for det forhold, at et givet prisniveau indenfor en branche vil svare til en indenfor denne branche faktisk eksisterende produktivitet, dvs. at markedsværdien vil ligge et sted mellem de grænser som sættes af den laveste og højeste individuelle vareværdi.

Markedsværdien som statisk størrelse, som affotograferet prisstørrelse, viser, at det er produktiviteten, dennes spredning på virksomheder og udbudefterspørgselsmekanismen, der afgør markedsværdiniveauet.

Markedsværdiniveauet reguleres som følger indenfor det niveauhierarki, som sættes af totalsummen af individuelle vareværdiers niveau, der ifølge produktionsprisens begreb over kortere perioder sagtens kan overskrides.

Lad mig afslutte præciseringen af markedsværdiens dynamiske og statiske indhold med følgende betydningsfulde citat fra bd. II af Theorien über den Mehrwert, s. 201-202, der efter min opfattelse bekræfter den fortolkning af markedsværdibegrebet, der er blevet udviklet i denne teoretiske fremstilling af konkurrencens begreb. ${ }^{23}$

Det fremgår af følgende citat helt klart, at markedsværdiniveauet tendentielt ligger på det aritmetriske gennemsnit af totalværdien produceret indenfor branchen over en cyklus, og at markedsværdien her indikerer et faktisk etableret produktivitetsniveau, der vil dominere en række virksomheder, og at dette produktivitetsniveau vil ligge på et mellemtrin af produktivitet indenfor branchen. Dette

23. Den trinitariske formel, se Das Kapital bd. III og Theorien über den Mehrwert, bd. III. 
sidste hører sammen med at cyklusen er den proces, hvori en given type konstant kapital udvikles, dominerer og forældes, og her tror jeg snarere Mandels cyklusbegreb, »den lange bølge«, der netop er afstemt efter teknikkens udvikling passer bedre som enhed for den processuelle værdi-pris-identitet end de traditionelle cyklusstørrelser: 7-8 år. ${ }^{24}$ Dette er indholdet af første afsnit i citatet. Andet afsnit belyser, at markedsværdiniveauet er afhængigt af produktivitetsniveauet, af det virksomhedsantal indenfor branchen, der repræsenterer det, samt af hvor stor en repræsentation af de andre trin det sameksisterer med over en kortere periode, samt endelig af udbud-efterspørgselsmekanismen:

»Værdien af en vare - der er produktet af en bestemt branche - er bestemt af den mængde arbejde, der er påkrævet, for at producere hele mangden, totalsummen af den produktionssfæres vareprodukt, og ikke af den særlige arbejdstid, der er påkrævet af hver enkelt kapitalist eller arbejdsgiver indenfor denne branche. De almene produktionsbetingelser og arbejdets almene produktivitet i denne særlige branche, f.eks. bomuldsfabrikation, er de gennemsnitslige produktionsbetingelser og den gennemsnitlige produktivitet indenfor denne branche: bomuldsfabrikation. Den kvantitet arbejde, hvorigennem f.eks. en alen bomuldsklæde er bestemt, er ikke den kvantitet arbejde der er den iboende, som fabrikanten har anvendt ved produktionen af den, men den gennemsnitslige kvantitet, hvorved alle bomuldsfabrikanter på markedet producerer en meter bomuldsklæde. De særlige betingelser, hvorunder de enkelte kapitalister producerer indenfor bomuldsfabrikationen, falder med nødvendighed i tre klasser. Den ene producerer ved middelbetingelser, det betyder, at de individuelle produktionsbetingelser, hvorunder de producerer, falder sammen med de almene produktionsbetingelser indenfor branchen. Gennemsnitsforholdet er dens virkelige forhold. (Middeltypens. OFK.) Dens arbejdsproduktivitet har den gennemsnitslige højde. Dens varers individuelle værdi falder sammen med varernes almene værdi. Hvis den (den midterste kapitaltype) f.eks. sælger bomuldsklædet for 2 shillings per alen, - hvilket er gennemsnitsværdien - så sælger den varerne til den vardi, som de af denne kapitaltypes kapitalister producerede alen faktisk indeholder. En anden klasse af kapitaler producerer under betingelser der er bedre end de gennemsnitslige. Deres individuelle vareværdier står under varernes almene værdi. Sælger de varerne til den almene værdi, så sælger de dem over deres individuelle værdi. Endelig producerer en tredie klasse under de gennemsnitslige produktionsbetingelser.

Men den produktmængde, der efterspørges fra denne branche er ingen fast størrelse. Går nemlig vareværdierne ud over visse rammer for gennemsnitsværdien, så falder mængden af den efterspurgte produktmængde, eller denne kvantitet efterspurgtes kun ved en given pris - eller i det mindste indenfor visse prisgrænser. Det er altså ligeså muligt, at den sidste klasse til stadighed må sælge deres varer under deres individuelle værdi, ligesom den bedstproducerende klasse til stadighed sælger varerne over deres individuelle værdi. Det vil nemlig afhænge af det numeriske forhold, eller af den proportionelle fordeling af virksomheder mellem klasserne, hvilken klasse, der vil afgøre gennemsnitsværdien. Hvis midterklassen er den langt mest dominerende, så vil den afgøre gennemsnitsværdien. Er denne klasse numerisk svag og den der producerer under gennemsnitsproduktionsbetingelserne numerisk stærk og dominerende, så vil den (dens individuelle produktværdi, OFK.) afgøre brancheproduktets almene værdi, selvom det hermed ikke skal være sagt, ja, at det er meget usandsynligt, at det netop skulle være den enkelte kapitalist i den sidste klasse af kapitaler, altså den dårligst producerende, der bestemmer afgørelsen«. (Marx’s fremhævelser. Min overs. OFK.)

Her kræves nemlig ekstraordinære betingelser af f.eks. politisk art, som det er tilfældet i bygge-, anlægs-sektoren, hvor det faktisk er de dårligste produktionsbe-

24. Mandel: Der Spätkapitalismus, Suhrkamp, 1973, kap. 4. 
tingelser, altså den højeste individuelle værdi, der regulerer markedsværdiniveauet. Overgangen til produktionsprisbegrebet bestemmes af det forhold at værdien af branchens totalprodukt over en given, kortere periode (som påpeget ikke en cyklus, hvad angår type-eksemplet), kan afvige fra den totale prissum det realiseres til.

Hvor ensartet pris på alle brancheprodukter, totalidentitet mellem værdi og pris over en cyklus, forskelligt profitrateniveau, og tendens til udligning af produktivitetsforskellene, en bevægelse, der rent faktisk repræsenteres af det midterste produktivitetsniveau alt efter mulighederne for dets numerisk stærke repræsentation blandt virksomhederne i branchen, vil regulere markedsværdien, så vil dette princip blive fraviget ved dannelsen af produktionsprisen, thi her kan profitten kun være ens mellem brancherne under den forudsætning, at der ikke dannes en enhedspris på produkterne. Og på baggrund af de helt forskellige stoflige forudsætninger for at producere automobiler og spagetti er det indlysende, at denne ensartede profit kun kan opnås ved at værdi og pris systematisk afviger fra hinanden i forholdet mellem brancherne, men er identisk på totalplan over en cyklus.

Marx præciserer tydeligt dette:

»Hver særlig branches markedsvardier, altså hver særlig branches markedspriser (hvis markedsprisen blot udgjorde »den naturlige pris« (Ricardos udtryk for individuel værdi. OFK.) altså blot udtrykte værdien i penge) ville give meget forskellige profitrater, da lige store kapitaler i hver forskellig branche (helt bortset fra de forskelle, der resulterer af deres forskellige cirkulationsprocesser) anvender konstant og variabel kapital i meget forskellige proportioner, altså giver meget forskellige merværdimasser og dermed profitmasser. Udligningen af de forskellige markedsværdier, således at den samme profitrate opstår indenfor de forskellige brancher, lige store kapitaler altså afkaster sammen gennemsnitsprofitter, er altså kun mulig gennem det forhold, at markedsvardierne forvandles til produktionspriser, der er forskellige fra de virkelige værdier « (Theorien über den Mehrwert, bd. II, s. 205, Marx's fremhævelser, min overs. OFK.)

Om gennemsnitsprofitraten og produktionspriserne gælder altså følgende:

\section{A) Dynamisk indhold:}

Dynamisk set er produktionspriserne og gennemsnitsprofitraten udtryk for, at kapitalen fordeles sådan på alle brancher, at profitniveauet i en branches livsforløb i forhold til alle brancher vil finde et ensartet niveau. Ekstra- eller minusprofitter kan ikke være noget permanent så længe produktet spiller en rolle for totalreproduktionen, dvs. så længe kapital kan tilføres og efterspørgselen variere.

Ricardo formulerer dette forhold kort og præcist:

»Det er det $\varnothing$ nske, som enhver kapitalist har om at flytte sine midler fra en mindre til en mere profitabel produktion, der forhindrer varernes markedspris i kontinuerligt at stå meget over eller meget under deres naturlige pris. Det er denne konkurrence, der i en sådan grad adjusterer varernes bytteværdi, at den tiloversblivende værdi eller overskydende masse, der er tilbage efter at lønnen for det arbejde, der er nødvendigt for deres produktion er betalt, foruden alle de andre udgifter, der kræves for at reproducere kapitalen på dens oprindelige niveau, indenfor enhver branche vil være proportional med den investerede kapitals størrlse.« (Ricardo: The Principles of Political Economy and Taxation. Everyman-udgaven, s. 50, Min overs. OFK.) 
Produktionsprisen kan i sit dymaniske aspekt ikke konstateres som et håndgribeligt, endeligt-etableret prisudtryk, men kommer til udtryk i det forhold, at der mellem brancherne enten må dannes et markedsværdiniveau med samme profitter $\mathrm{i}$ hovedparten af virksomhederne - hvilket naturligvis kun er muligt i brancher med samme stoflige betingelser for produktion - og/eller at ekstra- og minusprofitterne over cyklusen vil udligne hinanden. Som tendens kan dannelsen af gennemsnitsprofitraten og produktionspriserne indebære - ifølge dennes væsen - at totalpriserne på brancheproduktet kan ligge over totalværdierne indenfor en cyklus. Dette er et atypisk tilfælde hvad angår markedsværdibegrebet, da det korrigerer dette, men det er typisk nok hvad angår begrebet produktionspris, i hvis indhold begrebet »falsk social værdi « jo faktisk indgår konstituerende. Kun muligheden for afvigelsen mellem værdi og pris gør en faktisk såvel som tendentiel gennemsnitsprofitrate mulig.

Det tilfælde jeg her har i tankerne er tilfældet med den højproduktive branche, eller den lavproduktive branche, der ifølge stoflige årsager - undtagen landbruget og bygge-, anlægssektoren - ville ligge langt under og langt over gennemsnitsprofitten, hvis de »kun« skulle realisere den af dem producerede merværdi som profit.

Gennemsnitsprofitraten og produktionspriserne udtrykker altså, at sådanne underskud på brancheplan i værdi må opvejes af overskud på totalplan - thi ellers ville værdi og pris variere på totalplan - $\mathrm{i}$ alt fald hvis vi betragter et lukket (nationalt) system.

Dette sætter sig ikke igennem ved hjælp af hekseri, men betyder bare, at en ujævn fordeling af teknik og ressourcer, samt teknikkens stykvise og disproportionale udvikling i det kapitalistiske samfund gør det muligt, at varer produceret ved høj teknisk standard ikke sænkes tilsvarende i værdi når de sælges.

\section{B) Statisk indhold:}

At prisniveauet i en højproduktiv branche i dele af cyklussen ligger langt over den producerede værdi gør det selvfølgeligt vanskeligt at vide om pris indikerer værdi for et brancheprodukt. Her kan man dog skele til kapitalstørrelse, output og arbejdstimeantal for at se, hvad man kan tillade sig at slutte. Også ved tilfældet »falsk social værdi « ligger produktionsprisen borte fra markedsværdiniveauet, men i modsætning til den højproduktive branche, hvor produktionsprisen lå over markedsværdiniveauet (hvis dette udtrykker det aritmetriske gennemsnit af den over cyklussen producerede totalværdi i branchen, altså summen af individuelle værdier), ligger produktionsprisen nu under markedsværdiniveauet uden at dette markedsværdiniveau på totalplan over kortere tid er dækket ind, selvom markedsværdiens konkrete prisniveau udtrykker en konkret kapitaltype. Men disse tilfælde er alligevel atypiske hvad angår den helt generelle tendens for konkurrencen: udligning af produktivitetsniveauer og af profitrater.

I og med produktionsprisen jo betyder, at kapital med samme absolutte størrelse realiserer samme værdi uanset dens sammensætning, er det proble- 
matisk om man kan tale om produktionsprisen som et »statisk « begreb, som en affotograferbar størrelse. Thi begrebet en ensartet produktionspris i betydning et ensartet, numerisk identisk prisniveau er en kontradiktion. En ensartet pris kan kun give en ensartet profit, hvis alle kapitaler er ens sammensat. Men det er per difinition en ophævelse af konkurrencens begreb.

Produktionsprisen og gennemsnitsprofitraten eksisterer som statiske begreber, som direkte indikatorer for værdibevægelser i to tilfælde:

I) Hvor to eller flere brancher er så essentielle for totalreproduktionen, at profitniveauet i deres hyppigst repræsenterede kapitalsammensætning eksemplarisk regulerer profitniveauet i de andre brancher ved at sætte dets bundgrænse. Der skal her være tale om brancher med en støt, ikke-sæsonbestemt efterspørgsel og ikke overkapitaliserede brancher. Dette kan accepteres, da dette profitrateniveau trods alt kun kan være permanent indenfor kortere tid i cyklusen, og det er da også - som nævnt - den forestilling der bl.a. konstituerer Marx's begreb »den absolutte jordrente «.

II) Hvor kapitalens organiske sammensætning er så forskellig i alle brancher p.g.a. stoflige forskelligheder i produktionsteknik og produktform og funktion, at et numerisk identisk prisniveau ville være latterligt, dér dannes produktionspriserne netop som ensartede profitter på helt forskellige priser, da jo alene forskellige priser på forskelligt sammensatte kapitalers produkter gør en ensartet profit mulig. (Se her skemaerne i forbindelse med illustrationen af gennemsnitsprofitratebegrebet i Das Kapital, bd. III, s. 166 ff.)

At hver branches totalkapital ikke realiserer mere end gennemsnitsprofitten er bestemt af udbud-efterspørgsels-mekanismen, af de relativt faste produktionskoefficienter indenfor dele af cyklusen, og af merværdiratens ensartethed i hele samfundet. Denne sammenhæng udtrykkes ofte metaforisk i det vage begreb »værdioverførsel«, der har status af beskrivelse, ikke forklaring.

Begrebet produktionspris som fotograferbar term skulle betyde, at man direkte af priserne på brancheproduktet skulle kunne aflæse profitten. Det er selvfølgelig kun korrekt under meget særlige omstændigheder, fordi afgivelserne mellem ekstra- og minusprofitter kun kan opsummeres, hvis man kender en del til forholdene indenfor branchen i forhold til resten af samfundet.

Det kræver kendskab til de stoflige forskelligheder i produktionsbetingelserne at kunne aflæse profitbevægelserne indenfor de forskellige brancher, fordi profitstørrelserne i den borgerlige statistik tillige med omkostningsprisens indikatorer er temmeligt utilregnelige.

Men her gælder, at man må arbejde med det borgerlige materiale, der foreligger, og at man faktisk i vid udstrækning kan klare sig med indirekte indikatorer, ds. statistisk ikke behøver arbejde med begreber som variabel og konstant kapital, merværdi, merværdirate ect. 


\section{Kapitel 3}

\section{Sektor III's valoriseringsbetingelser}

I det følgende skal de foregående teoretiske overvejelser anvendes til at drage konklusioner om statsinterventionens objektive grundlag. Gennem inddragelsen af Marx' reproduktionsskemaer kan en tredie sektor udvikles (sektor III, skrives i det følgende SIII), der udgør alle de brancher, der direkte nyder godt af statens efterspørgsel i større målestok.

Pointen i det følgende bliver da, at gennemsnitsprofitraten i samfundet ikke indføres i denne sektor III og i vid udstrækning heller ikke i dens hovedleverandørbrancher, men at der her findes en højere profitrate og at denne kan vedvare på trods af forøget kapitaltilførsel.

I denne sektor og i dens leverandørbrancher findes altså et højere markedsværdiniveau i forhold til den stofligt mulige produktivitet end i det $\emptyset$ vrige samfund, fordi efterspørgslen er så stærk, at forøget kapitaltilførsel og dermed forøget udbud ikke vil sænke markedsværdiniveauet.

Statistikken giver ikke nogen mulighed for at bestemme om det er det laveste eller et lidt mindre lavt produktivitetsniveau, der regulerer markedsværdiniveauet, men det er givet, at markedsværdiniveauet ligger meget højt, hvilket de indirekte statistiske indikatorer viser. Der vil da skabes »falsk social værdi « i denne sektor og i dens leverandørbrancher, altså kunne realiseres ekstraprofitter, der ikke er produceret dér. Dette virker afgørende ind på betingelserne for totalreproduktionen.

Som eksempel på SIII har jeg valgt bygge- anlægssektoren og som dens leverandørbrancher dem, der i statistikken figurerer som henholdsvis »stenler- og glasindustri og »træ- og møbelindustri«. Valget er afhængigt af de tilgængelige statistikker og af den politiske rolle bygge- anlægssektoren spiller ved at være afgørende for formerne for arbejdskraftens reproduktion og ved at indgå i produktionen af fast kapital. At tage byggeanlægssektorerne som eksempel på SIII indebærer et brud med kriterierne for sektoropdelingen i Marx' reproduktionsskemaer, hvor den ifølge sin stoflige funktion i reproduktionsprocessen skulle høre under både sektor I og sektor II. Men valoriseringsperspektivet er i Marx' teori overordnet det stoflige perspektiv, afgørende bliver altså bygge- anlægssektorens rolle for den totale valoriseringsproces; og her må den ifølge sin financeringsform udskilles som en særlig sektor.

Valget af bygge-anlægssektoren som udtryk for SIII er dog problematisk af flere grunde:

For det første findes der i denne sektor en særlig form for profit, nemlig jordrenten, der indgår konstituerende i produktets pris. P.g.a. markedsværdiniveauets højde og permanens skabes der da både »falsk social værdi« 
indenfor produktion af boliger og anlæg, samtidig med at en af produktionsbetingelserne, jorden, i sin pris også indeholder den form for »falsk social værdi «, som Marx benævner »differentialrente«.

Det betyder, at der ved bygge- anlægssektorerne i selve produktionen både er tale om en profitform, der udspringer af et permanent overgennemsnitsligt profitrateniveau indenfor konkurrencens betingelser, og om en profitform, der gennem sit grundlag i monopolet på jord for en given gruppe mennesker konstitueres delvis udenfor konkurrencens betingelser.

Det bliver derfor nødvendigt kort at behandle problemet om jordrentens funktion indenfor byggeriet.

\subsection{Jordrenten og bygge- anlægssektoren.}

Ved bygge- anlægssektoren er produktion, cirkulation og distribution på punkter særegne i forhold til de øvrige sektorer i samfundet. For det første må man indenfor bygge- anlægssektoren skelne mellem produktion, cirkulation og distribution af boliger, erhvervsejendomme, institutioner og anlæg. Produktionsprocessen er her relativt identisk med den der foregår indenfor de andre brancher i samfundet i alt fald hvad angår den sociale form, men cirkulationen og distributionen kræver inddragelsen af elementet »grundareal «. Det betyder selvfølgelig ikke, at man kan producere en etageejendom i den bare luft, men det betyder, at grundarealets valoriseringsformer kommer ind i forbindelse med cirkulationen og af distributionen af den kapital, der er blevet anvendt ved produktionen og af de varer, der kom ud af den.

Selve produktionsprocessen er her identisk med den vi finder i det øvrige samfund med undtagelse af, at betingelserne for formindskelse af arbejdsmassen er mindre her end $\mathrm{i}$ industrien. Hvis der ved produktionen er tale om en adskillelse af producent og bygherre så adskiller cirkulationsprocessen sig kun ved, at den er langt hurtigere end ved alle andre varer p.g.a. realkreditten, og fordi produktionen indenfor denne sektor i meget vidt omfang foregår ved bestilling. ${ }^{25}$ Her forudsatte vi at bygherren ejede grundarealet hvorpå han lod bygge. Har producenten eller entreprenøen derimod ejet dette areal, så karakteriseres cirkulationen af det forhold, at der gennem den skal foregå en valorisering, der gør valoriseringen af den til grundarealopkøbet anvendte kapital mulig. (Vi forudsætter her, at entreprenør og grundejer kun i sjældne tilfælde falder sammen). Der vil da i cirkulationen indgå kravet om reproduktionen af den kapitaliserede jordrente. (se fremme).

Det er primært produktionen af boliger, erhvervsbygninger, institutioner og anlæg jeg tænker på, når jeg udvikler tesen om at der skabes »falsk social værdi« indenfor boligsektoren. Thi begrebet »falsk social værdi« - som det er udviklet her - er ikke systematisk adskilt fra de præmisser, der regulerer

25. Grue, ibd. s. 11. 
konkurrencens begreb, det beror altså hverken på monopol på jord eller i stoflige skranker for produktforøgelse- som det er tilfældet med de betingelser, som skaber jordrenten indenfor landbrugssektoren.

Karakteren af en prisstigning indenfor bygge- anlægsproduktionen er muliggjort af både værdiproduktionens og værdirealiseringens forøgelse. Altså muliggjort af den høje arbejdsintensitet indenfor byggeriet, - der ikke er slet så udtalt i forbindelse med anlægsarbejder - reperationsarbejdets store rolle her, og vanskelighederne med at rationalisere arbejdet på de store byggepladser.

I modsætning til de brancher, der leverer varer til byggeanlægssektoren, beror prisstigningerne her altså ikke udelukkende på »falsk social værdi«, men værdien, der tvinger priserne i vejret i forhold til resten af samfundet er til en vis grad produceret. På den anden side giver den forøgende anvendelse af betonelementer, der er præfabrikerede, og dermed af ufaglært arbejde indenfor byggeanlægssektoren mulighed for en stigende organisk kapitalsammensætning. Hertil kommer kravet til teknik ved bygningen af større fabriksanlæg, hospitaler, brokonstruktioner, tunneler og vejnet. Byggeanlægssektoren er altså ikke bare en arbejdsintensiv sektor med små og mindre virksomheder.

Det er vigtigt at afgøre om man kan tale om jordrente i egentlig forstand indenfor bygge- anlægssektoren. Det drejer sig her på den ene side om den absolutte jordrentes eksistens på den anden side om eksistensen af differentialrenterne.

Hvori består den absolutte jordrente?

Den består i det forhold, at den institutionelt (gennem monopolet på jord) og stofligt (gennem frugtbarhedsgrader) givne skranke for produktforøgelse indenfor landbruget skaber muligheder for at realisere produktet til en produceret værdi, der ligger over produktionsprisniveauet i resten af samfundet.

At byggeriet er mere arbejdsintensivt end resten af samfundet har intet at gøre med jordens karakter, det har derimod noget at gøre med byggeriets stoflige forudsætninger: at byggemodning f.eks. er afhængigt af meget arbejde i forhold til konstant kapital og at meget byggeri også er det. Problemet er altså: findes der i byggeanlægssektoren nogen skranker for kapitaltilførsel af institutionel eller stoflig art?

Svaret må blive bekræftende, fordi der findes afgørende institutionelle muligheder for at holde jord tilbage fra bebyggelse, der ikke kan sælges til en pris, der når den indgår i produktet fra denne sektor indeholder både jordrente og gennemsnitsprofit, altså gør realiseringen af produktet gennem salg eller leje muligt til en markedsværdi der ligger over gennemsnitttet indenfor industrien. At der er tale om »absolut jordrente « indenfor bygge- anlægssektoren fremgår klart af det forhold, at kun de jorde byggemodnes, der gennem salg eller leje kan give en pris, der indeholder både renter af den til grundkøbet anvendte kapital og den ved bebygningen af jorden fremskudte. (At jorden har en minimumspris betyder selvfølgelig ikke, at al jord må sælges, når det kan afkaste denne pris. Det er netop princippet ved al spekulation i jord at vente lidt længere). 
Kerneindholdet af begrebet »absolut jordrente « er, at dets forudsætninger er en begrænsning af kapitalbevægelsernes frihed og dermed af en gennemsnitslig udbudsmaksimering (som den findes indenfor industrien ved en given minimumsprofit). Disse forhold genfindes indenfor byggeriet.

Grundarealets værdi bestemmes altså - såfremt det er et jomfrueligt grundareal - af kapitaliseringen af den laveste rente som gør salg eller udleje af jord mulig til byggeformål: Indeholder grundarealet egenskaber, der er produkt af arbejde eller resultat af beliggenhed, kommer dets prisbestemmelse til at afhænge af kapitaliseringen af differentialrenten. Der er nemlig også tale om differentialrenter i forbindelse med bygge- anlægssektoren.

Differentialrente I er den ekstraprofit, der udspringer af lige store grundstykkers - med samme kapitalapparat - forskellige beliggenhed. Denne differentialrente kan tydeligvis konstateres $\mathrm{i}$ huslejen eller prisen på grundarealer modnet $\mathrm{i}$ lige høj grad, men med forskellig beliggenhed (og samme størrelse) indenfor en storbys areal f.eks. ${ }^{26}$ Det samme gælder differentialrente II, der angiver ekstraprofitter på lige store jorde med samme beliggenhed men med forskellige kapitalanlæg.

Her er dog tale om forskelle på bolig- erhvervs- og offentligt byggeri. For det første gælder det, at den absolutte jordrente blokerer for bygningen af boliger, der ved leje eller salg ikke kan give gennemsnitsprofitraten (som den findes i industrien) plus en ekstraprofit svarende til renten eller den kapitaliserede rente af grundarealets »værdi $\ll$. For det andet vil kun de virksomheder kunne opføres, hvis produktion vil kunne medvirke til at give en ekstraprofit gennem en forøgelse af produktiviteten. Privatejendommen på jord til fabriksog forretningsbebyggelse virker altså direkte blokerende på kapitalanlæg af industriel og handelsmæssig karakter.

Her findes dog den særegenhed hos offentligt byggeri og byggeri financeret af de almennyttige boligselskaber at udlejningspriserne er bestemt at omkostnings- og renteforholdene på den enkelte ejendoms opførelsestidspunkt og at stat og kommune kan stille grundareal til rådighed for sådant byggeri på helt andre betingelser end jord kan inddrages i det private byggeri. ${ }^{27}$

Hertil kommer at »erfaringerne fra mellemkrigstiden viser, at en række udlejere - især af mindre ejendomme i provinsen - undlader at benytte mulighederne for huslejeforh $\varnothing j e l s e r$ fuldt ud. ${ }^{28}$

Og endelig at huslejeloftet for den ældre boligmasse op til 1975 har skabt et prishieraki i boligmassen, der betyder, at det nye boligbyggeri kan give anledning til enorme priser og permanente ekstraprofitter. At der findes en overgennemsnitlig profitrate i nybyggeri i forhold til resten af samfundet siger Grue lige ud: ${ }^{29}$

26. Se Helga Fassbinder: Preisbildung, Monopol und Spekulation beim städischen Boden. Prokla, nr. 10, 1973.

27. Grue, ibd. s. 157.

28. Grue, ibd. s. 156.

29. Grue, ibd. s. 157. 
»Teoretisk bestemmes det nye boligbyggeris omfang under fri prisdannelse således, at der opnås samme forrentning af den investerede kapital i boligbyggeriet som ved andre investeringer. Tilpasningen foregår imidlertid så langsomt, at den teoretiske ligevægt kun sjældent nås. Selv under fri prisdannelse på boligmarkedet vil der være en ufuldkommen lejetilpasning i det eksisterende byggeri. I nybyggeriet vil en overnormal forrentning af den investerede kapital føre til en forøgelse af boligproduktionen. Da byggekapaciteten imidlertid er meget beskeden i forhold til boligbestanden, vil der i en årrække kunne opnås en unormal høj afkastning af investeringen i nyt boligbyggeri«.

Man skal her ikke lade sig narre af det forhold, at huslejelovgivningen forhindrer dannelsen af en enhedspris per $\mathrm{m}^{2}$ indenfor byggeriet: differentialrenterne eksisterer alligevel, således forstået, at det er den dårligst beliggende og modnede jord, der lægger minimumsprisen per $\mathrm{m}^{2}$. Ekstraprofitterne (differentialrenterne) kommer altså til udtryk som faktiske prisforskelle per $\mathrm{m}^{2}$, men det $g ø r$ ingen forskel fra differentialrentedannelsen indenfor landbruget, hvor ekstraprofitterne jo opstår på baggrund af en enhedspris på byg, rug, etc. Der er ligefuldt tale om realiseringen af »falsk social værdi «. Eksistensen af huslejelovgivningen, hvor en del af befolkningen kan få tilfredsstillet deres krav til lejligheds- størrelse og kvalitet, beliggenhed og fasciliteter til en pris langt under den, der betales for den samme mængde $\mathrm{m}^{2}$ i nybyggeriet accentuerer kun differentialrenterne og den absolutte jordrente ved at presse jordens salgs- og lejeværdi i vejret. (Renten er her årsag, salgs- og lejeprisen virkning).

Hvor minimumsforskelle i udstyr og beliggenhed altså giver store differentialrenter i nybyggeriet har huslejelovgivningen sat eksistensen af differentialrenterne ud af kraft på beboelsesejendomme til udlejningsformål, der omfattes af huslejelovgivningens rammer; forhold, der bl.a. er søgt omgået gennem oprettelsen af ejerlejligheder. Men dette ophæver ikke differentialrentens latente eksistens, der viser sig så snart ejendommen kan udstedes til ejerlejligheder eller blot når den sælges. Huslejelovgivningen kan dog ikke forhindre at der i den omfattede boligmasse findes en svag differentialrente af typen II, hvor altså lejlighedernes udstyr har begrundet svage forskelle i huslejen på baggrund af den ældre boligmasses nybyggeripris.

Disse restriktioner findes ikke i forbindelse med erhvervsejendomme, og differentialrenterne og den absolutte jordrente fungerer her uden restriktioner.

Det er her givet at både profitterne indenfor erhvervsbyggeri, udlejning og indenfor nybyggeri af boliger, ikke er værdimæssigt dækket ind. Ved nybyggeriet, hvor efterspørgslen skruer priserne yderligere i vejret, er der ikke givet nogen maximumsgrænse for profitterne, mens minimumsgrænsen naturligvis er gennemsnitsprofitten i industrien plus rentesatsen på lånene til byggeriet.

Det er klart, at mulighederne for kapitaliseringen af differentialrenterne og den absolutte jordrente gennem de almene vurderinger spiller en væsentlig rolle for etableringen af et forklaringskraftigt inflationsbegreb. Muligheden for omprioritering og for optagelsen af nye lån giver anledning til at en stor prissum kan fungere i samfundet uden at være dækket ind gennem vardiproduktion. 
Hvad enten denne masse er udstedt dækningsløst af staten eller skaffet gennem lån, så belaster den prisniveauet i samfundet ved at skrue efterspørgslen hårdt op og dermed muliggøre en lavere produktivitet i brancherne, og det slår tilbage på nationens position på verdensmarkedet og dermed igen på de internationale lånemuligheder. Staten viser sig her atter i sine interventionsformer ulykkeligt spiddet mellem hensynet til visse vælgergrupper (i dens boligpolitik) og hensynet til handels- og betalingsbalancen (og dermed til nogle andre vælgergrupper). Oveni kommer de muligheder der findes for at regulere boligmarkedet: obligationsop$\mathrm{k} \varnothing \mathrm{b}$ og -salg, byggerationering, diskontoregulering - disse muligheder er relativt virkningsløse. Naturligvis kan noget af den værdi, der udtrykker den realiserede differentialrente, i deltilfælde forklares gennem merværdi i pengeform anvendt som rentekapital, men på totalsamfundsmæssigt plan er differentialrente jo per definition netop det over gennemsnitsprofitten overskydende. Dette overskydende kan da næppe forklares som dækket ind af ekstraprofitten, altså som en størrelse, der realiseres gennem totalmerværdimassen.

\subsection{Bygge- anlægssektorens nøjere bestemmelser: Produktionens karakter.}

Bygge- anlægssektorens produktionsresultat havde i 1970 en værdi af cirka 18 milliarder kroner svarende til $14 \%$ af bruttofaktorindkomsten. Denne sektor indtager altså en fremtrædende plads i samfundsøkonomien. Det betyder at prisniveauet her vil have afgørende indflydelse på hele samfundet, fordi bygge- anlægssektorens produkt både indgår i arbejdskraftens reproduktion og i udgifterne til en stor del af den faste kapital, samt til skabelsen af de almene produktionsbetingelser. For det følgende er det vigtigt at understrege, at bygge- anlægssektoren er et udpræget hjemmemarkedserhverv..$^{30} » \mathrm{På} \mathrm{grund}$ af produktionens karakter er det i høj grad afskærmet fra udenlandsk konkurrence (i 1967 blev kun 1 promille af den samlede tilgang af bygge- og anlægsinvesteringer dækket af import.) Den yder intet bidrag til eksporten ${ }^{31}$ At bidraget til eksporten er meget ringe og kun gælder for særdeles få varearter bekræftes af skemaet $\gg$ Danmarks udenrigshandel med materialer til bygningsbrug 1950-1958« bag i Grues bog »Byggevirksomheden og den $\varnothing$ konomiske udvikling «.

Det er altså afgørende for markedsværdiniveauets konstans indenfor byggeanlægssektoren, at det ikke tvinges ned af udenlandsk konkurrence på hjemmemarkedet og af kravet om lav produktionspris, der svarer til afsætningsbetingelserne på verdensmarkedet.

30. Peter Wendt: Byggeri og boligforhold. København 1973, trykt i serien Erhverv og samfund, red. af S. A. Hansen. s. 15.

31. Wendt, ibd. s. 15. 
»Den særlige prisudvikling for bygge- anlægssektorens produktion og den deraf direkte eller indirekte afledede stigning i boligtjenesteprisen (og antageligt også i prisen på bygnings- og anlægstjenester i Øvrigt), som har fundet sted i 1960'erne, hænger sammen med sektorens beskyttelse mod international konkurrence. Indtægtsstigninger i resten af samfundet og den tilskyndelse til boligforbrug, som ligger i de direkte og indirekte subsidieringsordninger, har resulteret $i$ et vedvarende efterspørgselspres efter sektorens produktionsresultat i det meste af ti-året. Presset har givet sig udslag i en vækst i faktoraflønningerne, der langt fra er modsvaret af produktivitetsfremskridt. $^{32}$

Ikke engang bygge-anlægssektorens hovedleverandører er underkastet udenlandsk konkurrence på hjemmemarkedet på linie med andre ernhverv. Importkvoten for disse brancher er kun $9 \%$ mod $12 \%$ i resten af samfundet. ${ }^{33}$ Og Wendt mener at denne kvote snarere er faldet siden $1970 .{ }^{34}$ Anlægsaktivitetens muligheder for at bestemmes ad politisk vej har gjort udviklingen i denne del af sektoren mest stabil.

»Man kan derfor ikke for bygge- og anlægsvirksomheden - således som for den almindelige industrielle fremstillingsvirksomhed - tale om markeds $\emptyset$ konomiske drivkræfter. Bygge- og anlægssektoren er i meget væsentligt omfang en politisk styret virksomhed, og denne styring har i tidens løb været anvendt til ikke blot at fremme (eller hæmme) de egentlige bygningsmæssige formål, men også til at regulere den almindelige økonomiske udvikling med henblik på at tilvejebringe samfunds $\varnothing$ konomisk balance. $\ll^{35}$

Det første problem, der i forbindelse med bestemmelsen af prisniveauets årsager i denne sektor må behandles er spørgsmålet om bygge- anlægssektorens arbejdsintensive karakter.

Følgende faktorer giver bygge- og anlægssektoren en arbejdsintensivitet over gennemsnittet: ${ }^{36}$ For det første består en stor del af denne sektor af reperationsarbejde, der er meget vanskeligt at rationalisere gennem indførelsen af konstant kapital. For det andet er bygge- anlægssektoren af flere årsager ikke udviklet teknisk med samme homogenitet og intensitet som det er tilfældet $\mathrm{i}$ industrien. Grue anfører at byggetiden i årene efter 1945 har taget til p.g.a. mangelen på industriel organisering af arbejdet på de stadigt voksende byggepladser. ${ }^{37}$ Nørby anfører, at leverancesystemet for byggeriet er overordentligt desorganiseret, når undtages det såkaldte $»$ totalentreprisesystem $\ll{ }^{38}$ Den konstant stigende efterspørgsel og den manglende konkurrence fra og på verdensmarkedet har medvirket til at muliggøre den fortsatte eksistens af en række mindre firmaer i byg-

32. Wendt, ibd. s. 15-16.

33. Wendt, ibd. s. 15, Viggo Nørby: Rationalisering indenfor bygge- og anlægsvirksomheden, trykt i Strukturproblemer i Erhvervslivet, red. af H. Winding Pedersen og Kjeld Scherfig, i serien Studier fra Københavns Universitets Økonomiske Institut, nr. 18 s. 102.

34. Wendt, ibd. s. 15 , note 1 .

35. Nørby, ibd. s. 102.

36. Nils Groes: Kapitalbehov i forskellige erhverv og Peter Bjerregaard og Jarn Schauby: Det samlede kapitalbehov i de private erhverv, trykt i Kapital og Produktion, Forhold og perspektiver for erhvervene i Danmark, red. af Nils Groes, København 1975, s. 253 og 337. Se også PPII, s. 149.

37. Grue, ibd. s. 14.

38. Nørby, ibd. s. 100-101. 
geanlægssektoren. Et uelastisk akkordsystem kan også have været medvirkende til at lade den producerede værdimasse forblive stabil.

Alle disse forhold kan ved konstant merværdirate virke således, at den producerede merværdimasse ikke falder så stærkt i bygge- anlægssektorerne som i resten af samfundet, fordi den indfører et lavere organisk kapitalsammensætnings-gennemsnit; (hvilket ikke udelukker en række virksomheder med et for det samfundsmæssige gennemsnit meget højt sammensætningsniveau). Men disse forhold kan ikke forklare de kraftige prisstigninger i sektoren og tilvæksten i nyværdien.

Dette bekræftes at de rationaliseringerne og kapitalintensiveringen i denne sektor, der trods deres heterogenitet har været udbredt indenfor de seneste år.

For det første foregår $60 \%$ af det nye boligbyggeri v.hj. af præfabrikerede materialer og ufaglært arbejdskraft. ${ }^{39}$ Wendt anslår arbejdskraftforbruget ved industrialiseret byggearbejde til at være 4-5 gange lavere end ved traditionelt byggeri. ${ }^{40}$ Herved kommer omkostningerne ved traditionelt byggeri op på 50\% mere end ved montagebyggeri. ${ }^{41}$ Det gælder her, at byggeri af etageejendomme er meget mere industrialiseret end byggeri af enfamilieshuse og produktionsprisen per $\mathrm{m}^{2}$ følgeligt betydeligt lavere ${ }^{42}$ - et forhold, der tilsløres af at udlejningsprisen ikke bestemmes af den billigste $\mathrm{m}^{2}$-pris, men af den $\mathrm{m}^{2}$-pris, der svarer til den laveste produktivitet i byggesektoren.

Ifølge Tiårsoversigten 1975 er det primært arbejdslønnen, der har hævet byggeriomkostningerne fra 1968 til 1972 for muret etagebyggeri, enfamilieshuse og for en montagebygget ejendom. Prisen på materialer stiger samlet fra 1968 til 1972 med 25\% mens prisen på arbejdskraften (lønnen) stiger med 43\%. Men arbejdslønnens stigning indikerer her ikke ansættelse af flere arbejdere, altså ingen absolut stigning i merværdimassen ved konstant m'. Fra 10/6 1969 til 14/11 1972 sker der et absolut fald i totalantallet af arbejdere og arbejdende mestre ved privat og offentlig bygge- anlægsvirksomhed. ${ }^{43}$

Derimod udgør materiale- og varekøbet i regnskabsoplysningerne for bygge- anlægssektoren en noget større post end lønudgifterne. I 1972 gik 7.931.4 mill. kr. til materialer mod 5.337. o. mill. kr. til lønninger. ${ }^{44}$ Hertil kommer at reperationsarbejdets andel af den samlede byggeanlægsaktivitet er faldende. I 1958 udgjorde de 1/4 af investeringerne i sektoren. I 1969 1/10.45

Nørby anfører, at hvor nybyggeriet i $\mathrm{m}^{2}$ er steget fra 2,7 mill. i 1950 til 9 mill. i 1969 (altså en stigning på mere end 300\%), så er antallet af beskæfti-

39. Nørby, ibd. s. 104. Grue, ibd. s. 18-19.

40. Wendt, ibd. s. 61.

41. Wendt, ibd. s. 62.

42. Tiårsoversigten, 1975, s. 20.

43. Statistisk Årbog, 1971: s. 126-127. Statistisk Årbog 1974, s. 120-121.

44. Statistisk Årbog, 1975, s. 122-123.

45. Wendt, ibd. s. 45. 
gede ved bygge- anlægsvirksomhed kun steget knap 30\%, og her falder den væsentligste stigning på ufaglærte. ${ }^{46}$ Forbruget af arbejde er desuden faldet per $\mathrm{m}^{2}$ : ca. 24 timer per $\mathrm{m}^{2}$ i 1951 mod 19 timer i 1961 og 11 timer i $1964 .{ }^{47}$

Alligevel må Nørby konstatere:

»Mens produktionen per beskæftiget på byggepladsen er steget stærkt som følge af den foretagne rationalisering, kan samme gunstige resultater ikke afløses i prisudviklingen. Det må konstateres, at prisudviklingen i det industrialiserede byggeri har fulgt samme opadgående linie som priserne i det traditionelt fremstillede. Der er flere årsager hertil: det stærke efterspørgselspres og begrænset konkurrence har i alle led gjort det muligt at beregne sig rigelige fortjenstmarginaler. Det industrialiserede byggeri kræver en stor kapitaludrustning, der har nødvendiggjort store - og måske for store - afskrivninger. Endelig har man i byggeriet i vid udstrækning benyttet indvundne besparelser til kvalitetsforbedringer - bedre teknisk udrustning, fællesforanstaltninger og lign., som ikke umiddelbart kan aflæses af den foreliggende statistik. « ${ }^{48}$

Vi må altså slutte, at markedsværdiniveauet indenfor bygge- anlægssektoren gør realiseringen af en langt større værdi mulig end der faktisk er produceret dér.

Denne opfattelse bekræftes også af tallene for virksomhedssammensætningen indenfor bygge- anlægssektoren. I anlægssektoren er kaptalintensiteten ${ }^{49}$ størst, her er den organiske sammensætning højest. I byggeriet svinger kapitalintensiteten, men den højeste investeringsstigning i samfundet fra 1960 til 1972 findes indenfor byggefagene.$^{50}$ Den højeste kapitalsammensætning indenfor bygge- anlægssektoren findes foruden ved anlægsvirksomheden også ved montagebyggeriet. Byggeriet af en-familieshuse og etageejendomme v.hj. af traditionelle byggemetoder (ringe grad af præfabrikation, udtalt anvendelse af faglært arbejdskraft) er det mindst kapitalintensive byggeri. ${ }^{51}$ Også fabriksbyggeriet er kapitalintensivt, det foregår oftest v.hj. af kombineret stål- og betonbyggeri med ringe anvendelse af arbejdskraft fra de traditionelle byggefag. Arbejdsformen ligner den, der anvendes ved bro- og viaduktbyggeri. Det samme gælder bygningen af militære anlæg for det offentlige. ${ }^{52}$ Institutionsbyggeriet derimod vil p.g.a. sin høje installationsstandard have større arbejdsintensitet, selvom dette byggeri også er meget kapitalintensivt.

Præfabrikationen af typehuse har også forøget kapitalens organiske sammensætning indenfor bygge- anlægssektoren stærkt. ${ }^{53}$

Ser man på statistikken over forøgelsen fra 1969 til 1971, så viser det sig at stigningen i virksomhedsantallet i bygge- anlægssektoren er 5\%, men indenfor ka-

46. Nørby, ibd. s. 104.

47. Nørby, ibd. s. 105.

48. Nørby, ibd. s. 105.

49. Kapitalintensitet er et gradsudtryk, der i borgerlig terminologi angiver størrelsen af investeringerne i fast kapital og i råstoffer. Arbejdsintensitet angiver graden af arbejdstimeantal udgivet ved en given produktmasse, angiver altså værdiindhold.

50. Groes, ibd. s. 256.

51. Wendt, ibd. s. 62.

52. Grue, ibd. s. 27.

53. Groes, ibd. s. 257. 
tegorien »fremstillingsvirksomhed « kun 1\%. I brancherne sten-, ler- og glasindustri og træ- og møbelindustri er stigningen henholdsvis $7 \%$ og $1 \%$ for samme periode. ${ }^{54}$

Tager vi tabellen for bestand, tilgang og afgang af momsregistrerede virksomheder i 1971 ser vi, at afgangen i bygge- anlægssektoren i forhold til totalbestanden var 9\%, tilgangen $11 \%$. De samme størrelser for fremstillingsvirksomhed var: $10 \%$ og $9 \%$, altså en større afgang og en mindre tilgang end i bygge- anlægssektoren. For detailhandelen var tallene: $11 \%$ og $10 \%$. For transportvirksomhed: $12 \%$ og $12 \%$.

Kapitalens voldsomt heterogene anbringelse indenfor bygge- anlægssektoren bekræfter tesen om, at det høje regulerende markedsværdiniveau svarer til de individuelle værdier for en række små og uproduktive virksomheder, men at der samtidig findes en række store og højproduktive virksomheder indenfor branchen.

Entreprenørfirmaerne, der udgør de store virksomheder indenfor bygge- anlægssektoren, er gennemgående større end virksomhederne indenfor andre brancher ${ }^{55}$

Fra 1971 til 1974 sker der følgende bevægelser i virksomhedsantallet indenfor bygge- anlægssektoren: ${ }^{56}$

\begin{tabular}{|c|c|c|c|c|c|c|}
\hline Antal a & 2 & $5-6$ & $10-19$ & $50-99$ & $100-499$ & $500-$ \\
\hline Årstal & 7174 & 7174 & 7174 & 7174 & 7174 & 7174 \\
\hline Ent & 2477 & $30 \quad 240$ & 99206 & 8573 & 746 & \\
\hline & S & 71261 & 523 & 664 & 232 & 3 \\
\hline & 826901 & 662661 & 356362 & 2324 & 11 & - \\
\hline & & & & & & \\
\hline & & 30 & & 10 & & - \\
\hline & & 30 & & & & \\
\hline & 764629 & $507 \quad 409$ & 244215 & 611 & 79 & - \\
\hline
\end{tabular}

Udviklingslinien er her tydeligt, at de helt små firmaer er forøget indenfor alle

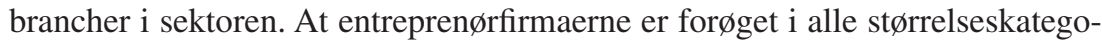
rier, men at de større håndværksfirmaer er faldet i antal. Dette tyder på de $\emptyset$ gede krav om kapitalintensitetkrav som entreprenørfirmaerne p.g.a. produktionens form: montagebyggeriet, lettest kan opfylde.

Den procentvise stigning i antallet af momsregistrerede virksomheder fra 1971 til 1972 indenfor bygge-anlægsvirksomhed og fremstillingsvirksomhed ved følgende kategorier af afgiftsangivet omsætning forholder sig således: ${ }^{57}$

54. Statistisk Årbog, 1974, s. 114-115.

55. Wendt, ibd. s. 49.

56. Statistisk Årbog, 1974, s. 118-119. Statistisk Årbog 1975, s. 122-123.

57. Statistisk Årbog 1974, s. 112-113. Statistisk Årbog 1975, s. 114-115. 
Stigning $i$ antallet af momsregistrerede virksomheder fra 1971 til $1972 i \%$.

\begin{tabular}{|l|c|c|c|c|c|}
\hline $\begin{array}{l}\text { Firmaom- } \\
\text { sætning }\end{array}$ & $0-49.999$ & $\begin{array}{c}50.000- \\
99.999\end{array}$ & $\begin{array}{c}2,5-2,9 \\
\text { millioner }\end{array}$ & $\begin{array}{c}5-9,9 \\
\text { millioner }\end{array}$ & $\begin{array}{c}10 \text { mil- } \\
\text { lioner }\end{array}$ \\
\hline $\begin{array}{l}\text { Bygge- og } \\
\text { anlægsvirk- } \\
\text { somhed }\end{array}$ & -8 & -1 & 22 & 6 & 11 \\
$\begin{array}{l}\text { Fremstil- } \\
\text { lingsvirk- } \\
\text { somhed }\end{array}$ & -6 & -3 & 6 & 13 & 4 \\
\hline
\end{tabular}

I kategorierne 0-49,999 kr. ligger bygge- anlægssektorens fald over fremstillingsvirksomhedens. I 50.000-99.999 kr-klassen ligger byggeanlægssektorens fald under fremstillingsvirksomhedens. Derimod stiger antallet af virksomheder i de større omsætningsklasser betydeligt mere for byggeanlægssektoren end for fremstillingsvirksomhed. Af tabel 111 og 113 i Statistisk Årbog fra 1974 viser det sig, at entreprenørfirmaerne udgør $8 \%$ af det samlede firmaantal, men har $47 \%$ af omsætningen og råder over $40 \%$ af de beskæftigede i bygge-anlægssektoren. Sammenlignet med murer- og tømrermestre ser forholdet således ud:

\begin{tabular}{|l|c|c|c|c|}
\hline$\%$ & Firmaantal & $\begin{array}{c}\text { Beskæf- } \\
\text { tigelse }\end{array}$ & Omsætning & $\begin{array}{c}\text { Bruttoind- } \\
\text { tjening }\end{array}$ \\
\hline Entreprenører & 8 & 40 & 47 & 46 \\
Murermestre & 21 & 23 & 18 & 19 \\
Tømrermestre & 19 & 12 & 11 & 11 \\
\hline
\end{tabular}

Entreprenørfirmaerne spiller altså en afgørende rolle indenfor byggeanlægssektoren.

Hertil kommer, at produktivitetsudviklingen generelt søges fremmet for hele byggeriet gennem særlige støtteordninger, der indeholder skranker for lav-produktive virksomheder. ${ }^{58}$

Der er altså belæg for den her fremførte tese om at det er et stort antal lavproduktive virksomheder, der regulerer markedsværdiniveauet inden for SIII, men at det er de store virksomheder, der realiserer ekstraprofitter og dermed påfører samfundet en stor masse »falsk social værdi«. Herved bringes den konstante og variable kapital i resten af samfundet til at stige og profitraterne formindskes da relativt i forhold til profitrateniveauet i bygge- anlægssektoren. Det permanent høje markedsværdiniveau og dermed realiseringen af permanente ekstraprofitter er kun mulig indenfor bygge- anlægssektoren p.g.a. efterspørgslens og udbuddets karakter:

58. Nørby, ibd. s. 102-104. 
Efterspфrgslen i bygge- anlaegssektoren:

Efterspørgslen skabes af følgende faktorer:

I) Offentlige anlæg. Udgør 1/4 af sektorens produktværdi. ${ }^{59}$

II) Erhvervsbyggeri. Ca. 25\% af det færdiggjorte boligareal lå i 1970 i erhvervsejendomme $.^{60} 39,9 \%$ af industriens investeringer i 1970 gik til byggeri. ${ }^{61}$

III) Offentligt erhvervsbyggeri.

IV) Privat etagebyggeri.

V) Privat parcelhusbyggeri. Post IV og V udgjorde $2 / 3$ af alt boligbyggeri i $1970 .{ }^{62}$

VI) Offentligt institutionsbyggeri.

VII) Reperation og vedligeholdelse.

I 1968 og 1972 gik henholdsvis 13\% og 14\% til bygge- anlægsarbejder og $14 \%$ og $13 \%$ til maskiner, transportmidler mv. af de faste bruttoinvesteringer. ${ }^{63}$

$2 / 3$ af det færdiggjorte boligbyggeri i 1970 var opført af private uden offentlig støtte. Hovedparten af den resterende trediedel var opført af boligselskaber. ${ }^{64}$ Resten af stat og kommune. Offentligt boligbyggeri voksede fra 1958 til 1970 med $12 \%$ årligt, det private med $10 \%{ }^{65}$

Staten spiller altså en stigende rolle ved efterspørgslen her. Ved det private erhvervsbyggeri spiller konjunkturerne afgørende ind. Efterspørgslens permanente stigning ud over udbuddet skyldes dog også fundamentale strukturændringer og politiske beslutninger: Overførslen af arbejdskraft fra land til by har fået boligbehovet til at eskalere. Udvidelsen af uddannelserne, socialvæsenet, etc, og etableringen af en omfattende infrastruktur har skruet efterspørgslen til byggeanlægssektoren op på et hidtil ukendt plan. Hertil kommer huslejeloftet i den ældre boligmasse, der har skabt et enormt pres på nybyggeriet. Også realkreditreguleringens overgang til den private sfære i 1958 har fået byggeriet til at stige.

Bygge- anlægssektoren er en sektor, hvor efterspørgslen kan forøges og formindskes politisk, men statens muligheder for at formindske den er mindre end dens muligheder for at forøge den. Byggerationering, rentepolitik, stop for offentligt byggeri er midler i statens hænder, men disse kan ikke skabe den konkurrencesituation i bygge- anlægssektoren, der alene kan presse pris- og aktivitetsniveauet ned.

Udbyddet i bygge- anlaegssektoren:

Udbuddet har vi behandlet i det foregående, her skal blot foretages en systematisk rubricering af dets faktorer:

59. Wendt, ibd. s. 15.

60. Wendt, ibd. s. 54.

61. Groes, ibd. s. 322. (beløbet angives i faste priser.)

62. Wendt, ibd. s. 53.

63. Tiårsoversigten, 1975, s. 84. Beløbet er angivet $\mathrm{i}$ årets priser.

64. Wendt, ibd s. 53.

65. Wendt, ibd. s. 54-55. 
I) Udbuddet stiger indenfor bygge- anlægssektoren gennem en stor tilgang af både mindre og meget store kapitaler.

II) Udbuddet skifter karakter i retning af montage-byggeri og typehusproduktion.

III) Udbuddet kan ikke dække efterspørgslen på boliger p.g.a. den af differentialrenten oppressede jordpris i byområder, der giver alt for høje leje- og købspriser; og p.g.a. den for langsomme vækst i boligantallet i forhold til væksten i boligforbrugende grupper.

IV) Importen spiller en minimal rolle. Det samme gør konkurrencen på verdensmarkedet gennem eksport.

V) Bygge- anlægssektorens særlige lånemuligheder har gjort en meget stor produktion mulig, men har samtidig begrænset denne til sådanne typer af produktion, der har kunnet afkaste en profit, der både har kunnet dække en gennemsnitsprofit plus jordrente plus renteudgifter til lån. Endelig er det private byggeri blevet inspireret til på trods af prisniveauet gennem skattefordele at forøge reallønnen: et stigende antal lønmodtagere har erhvervet egen bolig.

Afgørende for hele vores problematik er det, at udbuddet ikke har kunnet påvirke markedsværdiniveauet i nedadgående retning, at konkurrencens begreb synes at modificeres i denne sektor.

Virkningerne af en sådan sektor på totalreproduktionen er overordentlig negativ, da den indgår konstituerende for både konstant og variabel kapital og dermed kan hæve omkostningsprisen afgørende, og sænke reallønnen for visse lønmodtagergrupper.

Som den borgerlige $\varnothing$ konomi har erkendt skaber dette sociale uroligheder og vanskeligheder for den nationale kapital på verdensmarkedet. Ikke alene realiseringen af differentialrentesummen gennem lån i fast ejendom og gennem jord- og ejendomshandel belaster $\varnothing$ konomien ved at realisere enorme prissummer, der ikke er dækket ind gennem en produktion af brugs- og bytteværdi; men også virkningen på industriens omkostningsniveau og på reallønnen skaber skævheder i totalreproduktionen, fordi kapitalisterne i de ramte brancher søger at kompensere for prisstigningerne på konstant kapital gennem prisstigninger og rationaliseringer i arbejdsprocessen, og fordi lønmodtagerne reagerer med kravet om højere løn og bedre arbejdsbetingelser.

Endelig skal pengene til at realisere den »falske sociale værdi« i denne sektor skaffes et eller andet sted fra, og dermed belastes betalingsbalancen og hele det nationale kreditsystem.

\subsection{Valoriseringsbetingelserne i bygge-anlægssektorens hovedleverandør- brancher}

Bygge- anlægssektoren er ikke ene om at have et overgennemsnitsligt markedsværdi- og profitrateniveau. De to brancheklynger, der leverer hovedparten af 
bygge-anlægssektorens varer er hvad angår efterspørgselsog konkurrencebetingelserne næsten lige så privilegerede. Det drejer sig om de brancheklynger, der $\mathrm{i}$ industristatistiken hedder »sten- ler og glasindustri« og »træ- og møbelindustri«. I det følgende optræder de under forkortelserne STI og TRI. (»I« refererer til deres status af sektor I brancher, brancher altså, der leverer varer til at udgøre den konstante kapital).

Disse brancheklynger udmærker sig ved at være afgørende bestemt af væksten indenfor sektor III, og dermed indirekte af den statslige efterspørgsel. I det følgende skal jeg gennem opridsningen af en række indikatorer vise, at markedsværdiniveauet ligger højere i disse brancheklynger end i resten af samfundet (når undtages bygge- anlægssektoren), ja at de ligger næsten på linie med bygge-anlægssektoren (når der tages højde for de stoflige forskelligheder i produktionsprocessen) hvad angår profitrateniveau og at der også i disse brancheklynger skabes »falsk social værdi«, fordi der over et længere tidsrum ikke dannes en produktionspris, at gennemsnitsprofitrateniveauet altså ikke trænger igennem her.

A) Importen er ringe for STI- og TRI-varernes vedkommende. Importkvoten udgjorde for rå- og hjælpestoffer plus tjenester kun 9\% (af sektorens samlede produktionsværdi) i 1958 mod $12 \%$ for alle andre brancher under ét. ${ }^{66}$ Wendt anfører også, at den formodentligt snarere er faldet siden dengang. ${ }^{67}$ Importen af varer til byggeriet er beskeden, den udgør kun 5-6\% af den samlede import. ${ }^{68}$ Konkurrencen for STI og TRI på hjemmemarkedet fra fremmede firmaer er altså relativ svag og kan ikke i samme grad som ved andre brancher tvinge markedsværdien nedad gennem en forøgelse af udbuddet eller gennem kvalitetskonkurrence.

Således har STI den højeste \%-del indenfor industrisektoren af hjemmemarkedet i forhold til den del, der dækkes af importerede varer, nemlig 74,9\% i 1969, hvor gennemsnittet er 39,7\%. TRI har 37,7\% af hjemmemarkedsomsætningen indenfor denne branche på danske virksomheders hænder. Denne brancheklynge er altså i langt højere grad end TRI udsat for konkurrence,hvilket da også viser sig i indikatorerne for udviklingen indenfor de to klynger. ${ }^{69}$

Også hvad angår eksporten er STI mindre udsat for konkurrence end TRI. Eksporten i \% af produceret værdi er i 1965 for STI 11\% mens den er 18\% for TRI. Det er for STI's vedkommende især eksporten af cement, der har været faldende. For TRI's vedkommende består $64 \%$ af eksporten af møbler. ${ }^{70}$

66. Wendt, ibd. s. 15. Der er tale om bygge-anlægssektorens samlede produktværdi.

67. Wendt,ibd. s. 15 , note 1 .

68. Grue, ibd. s. 169.

69. S. Å. Hansen, Industri og håndværk, udgivet i serien Erhverv og Samfund, red. af S. Å. Hansen, København 1972, s. 60.

70. S.Å. Hansen, ibd. s. 58-59. 
B) Virksomhedsantal og virksomhedsstørrelse indenfor STI og TRI viser også, at der er tale om en række mindre virksomheder med relativt lav produktivitet samt en række store og meget store virksomheder med høj produktivitet.

»Den kemiske industri og sten, -ler- og glasindustrien er kendetegnet ved, at stordriften er fremherskende indenfor nogle specielle industrigrene, medens virksomhederne i andre brancher har en meget ringe gennemsnitsstørrelse. $\ll^{71}$

Og » Træ- og møbelindustrien består i overvejende grad af mindre virksomheder. Indenfor papir- og grafisk industri er der tale om typisk stordrift... «"2

Virksomhedsfordelingen i de to brancheklynger ser således ud:

Virksomhedsantallet $i \%$ af totalvirksomhedsantallet fordelt på virksomhedsstørrelser efter antallet af ansatte. ${ }^{73}$

\begin{tabular}{|l|c|c|c|}
\hline Antal ansatte & $10-19$ & $50-99$ & $500-99$ \\
\hline STI & 34 & & 0,7 \\
TRI & 39 & 8 & 0,3 \\
Kemisk industri & 26 & 19 & 3 \\
Tekstilindustri & 27 & 15 & 0,2 \\
Næringsmiddelindustri & 24 & 15 & 0,8 \\
Jern- og metalindustri & 33 & 12 & 0,3 \\
\hline
\end{tabular}

Det er tydeligt, at både STI og TRI er stort repræsenteret blandt de små virksomheder, og at STI er godt repræsenteret blandt de større.

C) At prisniveauet og prisstigningerne i disse brancheklynger ligger over gennemsnittet er hævet over enhver tvivl:

Varditilvaeksten i \% af produktvardien. 1971, udvalgte brancher ${ }^{74}$

\begin{tabular}{|l|l|}
\hline STI & 66 \\
TRI & 52 \\
Kemisk industri & 45 \\
Tekstilindustri & 46 \\
Næringsmiddelindustri & 26 \\
Jern- og metalindustri & 53 \\
\hline
\end{tabular}

71. S.Å. Hansen, ibd. s. 26.

72. S.Å. Hansen, ibd. s. 26.

73. Statistisk Årbog.

74. Statistisk Årbog 1974, s. 126. 
Stigninger i værditilvæksten for i alt fald STI følger af følgende skema, der angiver kvantum- og værdibevægelser indenfor industrien fra 1970 til 1971:

\begin{tabular}{|l|c|r|r|r|r|r|}
\hline & \multicolumn{2}{|c|}{} & \multicolumn{2}{c|}{$\begin{array}{c}\text { Totalprodukt- } \\
\text { massen }\end{array}$} & \multicolumn{2}{c|}{ Totalværdien } \\
\hline & $\begin{array}{c}\text { total- } \\
\text { produkt }\end{array}$ & $\begin{array}{c}\text { total- } \\
\text { værdi }\end{array}$ & udførsel & $\begin{array}{c}\text { ind- } \\
\text { førsel }\end{array}$ & udførsel & $\begin{array}{c}\text { indfør- } \\
\text { sel }\end{array}$ \\
\hline STI & 3 & 424 & 51 & 11 & 1 & -14 \\
TRI & -1 & 19 & 15 & -14 & 2 & 2 \\
Kemisk industri & -1 & 562 & 1 & 3 & 7 & 1 \\
Tekstilindustri & 1 & 74 & 31 & 18 & 3 & 1 \\
Transportindustri & 13 & 457 & -15 & -18 & 9 & -25 \\
\hline
\end{tabular}

I STI falder indførselsværdien, men dets kvantum stiger, værdistigninger i denne branche er altså ikke forårsaget af stigninger i importpriserne. Udførselskvantummet fra STI og TRI stiger, mens udførselsværdien stiger meget lidt. Det kan tyde på stigende materialeintensitet og produktivitet i de to brancher.

Hertil kommer yderligere et indeks for vareværdierne: det drejer sig her om en sammenligning mellem stigningen i kvantum sammenholdt med stigningen i værdi for visse varegrupper fra 1968 til $1973 .{ }^{75}$ Disse tal bliver dog mangelfulde, da der ikke findes nogen mængdeangivelser for TRI og kun relativt få for STI:

\begin{tabular}{|lcr|}
\hline & Kvantum & Værdi \\
\hline Cement & $26 \%$ & $83 \%$ \\
Varer af asbestcement & $26 \%$ & $82 \%$ \\
Ildfaste sten, blokke & $-5 \%$ & $18 \%$ \\
Fliser og lign. & $26 \%$ & $54 \%$ \\
Tagsten & $16 \%$ & $74 \%$ \\
Molersten & $60 \%$ & $66 \%$ \\
Isoleringsglas af flere lag glas & $255 \%$ & $303 \%$ \\
Planglas, trukket, ufarvet & & \\
\hline
\end{tabular}

Sammenligner vi disse tal med tal for stigninger i kvantum og værdi indenfor andre brancher ser vi, at produktivitetsstigningerne slet ikke er fulgt af så stærke værdistigninger som i STI:

75. Statistisk Årbog, Statistisk Årbog 1971 og 1974. 


\begin{tabular}{|l|c|c|}
\hline & Kvantum & Værdi \\
\hline Blyakkumulatorer og startbatterier & $29 \%$ & $59 \%$ \\
Konservesdåser & $40 \%$ & $74 \%$ \\
Klare lakker, pigment lakker & $28 \%$ & $35 \%$ \\
Sæbe & $5 \%$ & $27 \%$ \\
Papirmasse & $9 \%$ & $15 \%$ \\
Gulvtæpper & $48 \%(1969)$ & $43 \%$ \\
Tråd af kobber & $9 \%$ & $-8 \%$ \\
Tegnebøger, punge, mapper af læder & $63 \%$ & $41 \%$ \\
\hline
\end{tabular}

Markedsværdiniveauet synes altså at ligge noget over andre brancher i STI.

D) Det er nu vigtigt at vise, at prisniveauets højde (værditilvæksten) i STI og delvis i TRI, for så vidt pris- og profitniveauet på punkter også her ligger over gennemsnittet, ikke skyldes, at disse brancheklynger er arbejdsintensive ud over det almindelige. Det højere markedsværdi- og profitrateniveau skyldes altså ikke at der produceres meget mere værdi her end i andre brancher, men at der realiseres mere.

Allerede det forhold, at der findes en lang række kapitalintensive, store firmaer i disse klynger tyder på, at værditilvæksten ikke skal søges i lav organisk sammensætning alene. Men også indikatorer på kapitalintensiteten i forhold til arbejdskraftmassen i disse klynger bekræfter tesen:

Variabel kapital og afskrivninger $i \%$ af totalomsatningen. Udvalgte brancher. ${ }^{76}$

\begin{tabular}{|l|c|c|c|}
\hline & Variabel kapital & \multicolumn{2}{|c|}{ Afskrivninger } \\
\hline år & 1972 & 1967 & 1972 \\
\hline STI & 29 & 7 & 7 \\
TRI & 27 & 3 & 3 \\
Næringsmiddelindustri & 14 & 2 & 2 \\
Tekstilindustri & 28 & 4 & 3 \\
Kemisk industri & 21 & 4 & 4 \\
Jern- og metalindustri & 31 & 3 & 3 \\
\hline
\end{tabular}

STI og TRI er altså ikke mere arbejdsintensive end gennemsnittet af brancher. Hvor TRI's kapitalintensitet ligger på gennemsnittet af branchernes, ligger STI's åbenbart betydeligt over resten af branchernes.

76. Statistisk Årbog, industriens regnskaber. 
Den større værditilvækst må altså søges $\mathrm{i}$ andre forhold end produceret værdi. Endelig kan det også vises, at der ingen entydig sammenhæng er mellem stigninger i arbejdstimetallet og værditilvæksten indenfor brancherne: ${ }^{77}$

Stigning $i$ antallet af udforte arbejdstimer og varditilvaksten minus lon $i \%$ fra 1971 til 1972.

\begin{tabular}{|l|r|r|}
\hline STI & 1 & 8 \\
TRI & 5 & 2 \\
Kemisk industri & 1 & -6 \\
Næringsmiddelindustri & -3 & 5 \\
Tekstilindustri & -3 & -1 \\
Jern- og metalindustri & 1 & 7 \\
\hline
\end{tabular}

Dette bekræfter altså heller ikke, at værditilvæksten skulle skyldes produktion indenfor klyngerne TRI og STI.

Endelig bekræfter indikatorerne på profitraterne $\mathrm{i}$ industriens afdelinger, at værditilvæksten i STI og TRI ikke kan skyldes »overført « værdi fra flydende kapital - desuden fraregnes denne post netop ved den statistiske bestemmelse af begrebet »værditilvækst $:^{78}$

Bruttoindtjening $i \%$ af totalomkostninger.

\begin{tabular}{|l|r|r|c|}
\hline år & 1967 & 1970 & 1972 \\
\hline STI & 17 & 18 & 16 \\
TRI & 9 & 10 & 11 \\
Næringsmiddelindustri & 7 & 7 & 7 \\
Kemisk industri & 10 & 10 & 8 \\
Jern- og metalindustri & 9 & 9 & 8 \\
Transportindustri & 3 & -2 & - \\
\hline
\end{tabular}

E) Tilbage bliver at argumentere for, at det heller ikke er lønstigninger, der forøger værditilvæksten så ekstraordinært i de to klynger. Allerede profitrateniveauet viser jo at det vanskeligt kan være rene lønstigninger der tæller så tungt i værditilvæksten, men andre indikatorer findes:

Skulle lønstigningerne på værditeoriens præmisser kunne forklare værditilvæksten, så skulle det ske gennem en fremhævelse af en forøget værdiproduktion på baggrund af en konstant eller labil merværdirate.

77. Tiårsoversigten 1975, s. 28.

78. Tiårsoversigten 1971, Statistisk Årbog 1974 og 1975. 
$\mathrm{Nu}$ har vi allerede set, at stigninger i arbejdstimetallet ikke viser nogen direkte sammenhæng med udsvingene i værditilvæksten. Derimod er der en tydelig sammenhæng mellem værditilvækst og lønstigninger:

Løn-, vardi- og arbejdstimetilvakst $i$ STI og TRI $i$ \% af forudgående år.

\begin{tabular}{|l|c|c|c|c|}
\hline år & $1965-1966$ & $1967-1968$ & $1970-1971$ & $1971-1972$ \\
\hline Løntilvækst i STI & 10 & 5 & 13 & 13 \\
Værditilvækst i STI & 9 & 7 & 11 & 16 \\
Løntilvækst i TRI & 10 & 14 & 3 & 18 \\
Værditilvækst i TRI & 6 & 16 & 3 & 19 \\
Arbejdstimetilvækst & -4 & -6 & -2 & 1 \\
i STI & & & & \\
Arbejdstimetilvækst & -3 & 3 & -9 & 5 \\
i TRI & & & & \\
\hline
\end{tabular}

Vi har umiddelbart både lønstigninger og profitstigninger samtidig med at vi har fald i arbejdstimetallet, både absolut og relativt. Det opkaster et teoretisk problem ved hvis kerne denne artikel har villet røre: hvor kommer denne værditilvækst fra, når den ikke er produceret?

Svaret kunne her blive - som f.eks. Altvater og co. har villet set det i Probleme des Klassenkampf nr. 17/18, - at kapitalistklassen blot forhøjer priserne og derigennem henter profitterne hjem og bøder for deprecieringen af den konstante kapital. Men denne løsning er ukorrekt:

For det første ligger det i kapitalens begreb at maximere sit afkast så meget som muligt. Dette sker på konkurrencens niveau gennem en løsrivelse af priserne fra værdierne i de enkelte kapitalomslag og varemetamorfoser. Kapitalens begreb er her den struktur, der formidler mellem væsensplanet og fremtrædelsesdimensionen: værditeorien kan ikke forklare prisbevægelser, der kendetegnes af en adskkillelse af pris og værdi. Det kan princippet i kapitalens begreb derimod, thi her ligger den logik accentueret, at værdi og pris $m a ̊$ afvige af hensyn til profitmaximeringen. Som det egentlig ligger implicit i hele Grundrisses fremstilling er profitmaximeringsloven, altså valoriseringsprincippet, det mest overordnede princip i hele den marxske videnskab om kapitalismen. Kapitalens profithunger er så stor, at selv værdiloven i øjeblikke må ophæves. Men denne ophævelse sker kun momentvist og kan aldrig være noget permanent, tendentielt eller principielt: hvor enkeltkapitaler og branchekapitaler over bare en kortere tid kan realisere enorme profitter, så forhindrer loven om dannelsen af produktionspriserne og gennemsnitsprofitraten at dette bliver noget permanent, og dermed at det bliver et generelt forklaringsprincip: prisstigningerne i kapitalismen kan godt forklares ved - i alt fald som delmoment af en forklaring - at priserne sættes op i alle brancher for at modvirke stigninger i omkostningsprisen. Men stigninger i profitten kan ikke forklares herigennem, fordi de hvis de gælder hele samfundet må være 
resultatet af enten et fald på sektor II's produktværdier, eller af et fald i reallønnen p.g.a. visse ændrede betingelser for klassekampen. Lokale stigninger i profitten af mere permanent karakter derimod er mulige på baggrund af en konstant merværdirate for hele samfundet, og indebærer realiseringen af en værdimasse, der ikke er produceret.

Marx belyser dette problem med al ønskelig klarhed i Theorien über den Mehrwert bd. II, s. 126-127. Han siger nemlig her, at kun den stigende markedsværdi i landbrugssektoren kan forklare landbrugsprisernes stigende prisniveau i begyndelsen af det 19-nde århundrede i England. I denne forbindelse afviser han følgende forklaringer på prisstigningerne:

»Det kan ikke forklares v.hj. af deprecieringen, thi det ville nok kunne forklare hvorfor industriprodukternes (priser) faldt ved større udvikling af produktiviteten indenfor industrien, altså hvorfor landbrugsprodukterne steg relativt i pris. Men det ville ikke kunne forklare hvorfor landbrugsprodukternes priser foruden denne relative stigning fortsat steg absolut. Ejheller kan det forklares ud fra profitratens fald. Thi denne ville aldrig kunne forklare en prisændring, men kun en andring i fordelingen af værdien eller prisen mellem godsejer, kapitalist og arbejder«. (Min overs. OFK. Marx’ fremhævelser.)

Det er den sidste sætning, der er væsentlig her:

Marx' underforstår her, at merværdiraten er konstant, og hævder så, at prisstigninger som følge af den produktionspris, der skabes, hvis omkostningsprisen stiger og profitraten er konstant, er utænkelige, fordi de vil blive fulgt af lønstigninger - thi det ligger i det definitoriske udgangspunkt, der samtidig afspejler klassekampens spændingsforhold: merværdiratens konstans (over en given periode).

Selvfølgelig er netop pris-løn-spiralen et billede på klassekampens betingelser under kapitalismen, men den kan til syvende og sidst kun forklare profitterne som et resultat af en udhuling af reallønnen, og ikke som resultat af de handels- og finansmæssige forhold mellem nationerne på verdensmarkedet, og af forholdet mellem produktivitetsudvikling, udbud og efterspørgsel i brancherne i samfundet. Sådan en løsning må kort sagt focusere på de lønbegrænsende virkninger af indkomstpolitik især og kan ikke forstå statens andre og afgørende måder at intervenere i den kapitalistiske $\varnothing$ konomi på.

Anskuet på niveauet for konkurrencen og anskuet både på branche- og på totalplan er det tydeligt, at netop kapitalens væsen, dens profitmaksimeringstrang, udelukker profitstigninger på brancheplan, der er resultatet af en viljemassig stigning i udsalgsprisen. Jeg mener her stigninger sat efter overvejelser og sat bevidst således, at prisen er opnået ved at der er lagt en langt større procent end gennemsnittet til omkostningsprisen.

Princippet for dannelsen af produktionspriserne og gennemsnitsprofitraten vil forhindre sådanne operationer ved at suge kapital til branchen og ved at de kapitaler, der anvender produktet fra de prisløbske brancher i deres produktion skifter til alternative produktionsmetoder, importerer eller yder pression ad anden vej.

Det betyder altså, at enhver mere permanent afvigelse fra gennemsnitsprofitraten besvares i formerne for reproduktion gennem boykotning af de dyrere produk- 
ter eller gennem kapitaltilførsel til sådanne profitfede brancher. Kun ad én vej kan denne proces blokeres og det dér via en instans, der står uden for totalreproduktionen ved ikke at være underkastet valoriseringsprincippet, kort sagt via staten.

Det er statens efterspørgselsskabende aktion der kan give grundlag for et midlertidigt stop i konkurrencens maskine, men det har frygtelige følger for den kapitalistiske $\varnothing$ konomi, der er så sensibel overfor mangel på balance, p.g.a. produktionens klassestruktur.

\subsection{Inflation og omkostningsprisstigninger}

Der er stor rimelighed $\mathrm{i}$ at antage, at en af inflationens årsager er de relative prisstigninger i sektor III og i dens leverandørbrancher. Det er det manglende fald i markedsværdierne i sådanne sektorer og brancher, der bl.a. skruer priserne op. Dette manglende fald, der kommer til udtryk som en overgennemsnitslig prisstigning i forhold til andre branchers prisniveauer, er forårsaget af en efterspørgselssituation, der over en vis periode sætter konkurrencens mekanismer ud af kraft. Statsinterventionens negative følgevirkninger er altså bl.a. prisstigninger i visse brancher og dermed ulige udviklingsbetingelser for alle kapitaler.

Men det manglende fald i markedsværdierne i sektor III og dens leverandørbrancher og dermed skabelsen af »falsk social værdi«i samfundet er kun en af flere årsager til inflationen. Følgende årsager skal yderligere behandles på baggrund af konkurrencens begreb:

I) Råvareprisstigninger, stigninger på fast kapital og branchespecifikke lønstigninger: disse stigninger udgør alle en stigning i enkeltkapitalens omkostningspris. Virkningerne på profitmassen afhænger af branchens konkurrencesituation. Hvis efterspørgslen er stærk nok vil profitraten kunne holdes relativt stabil, fordi markedsværdiniveauet kan øges. Ellers vil - ved labil eller faldende efterspørgsel - de prisstigninger være umulige, der ville kunne sikre en konstant profitmasse. Konkurrencen vil altså her resultere i et undergennemsnitsligt profitrateniveau indtil det - af denne årsag - faldende udbud (p.g.a. kapitalafvandring) skaber en efterspørgselskvote, der gør en gennemsnitsprofit mulig. Problemet er her, hvad der sker hvis efterspørgslen er så stærk, at de prisstigninger der skal justere profitraten til det nye omkostningsniveau, således at profitmassen forbliver stabil, er mulige som et mere permanent fænomen? Hvis altså brancheproduktet indgår som et helt uundværligt moment i en hel række branchers produktionsproces - som det f.eks. er tilfældet med olieprodukterne?

Permanente prisstigninger her vil enten skabe:

a) et lavere profitrateniveau i en hel række brancher indenfor en eller flere nationers rammer, hvis der ikke er mulighed for alternative råvarer, maskiner eller specialuddannet arbejdskraft; eller

b) prisstigninger, der holder profitraten stabil, men skaber masser af »falsk social værdi «, der skal hentes gennem statslig underbudgettering, lån i udlandet, reallønsfald, etc.; eller 
c) prisstigninger, der er dækket ind gennem en øget merværdirate, der altså kræver faldende realløn eller/og forøget intensivering af arbejdet, forlængelse af arbejdsdagen, etc.

Alle disse virkninger er farlige for roen på arbejdsmarkedet og dermed for »borgfreden « mellem klasserne.

Det væsentlige forhold her er især prisstigninger på råvarer forårsaget af monopol-stillinger omkring udbuddet, af stoflige grænser for mekanisering af produktionen af råvarer, eller af direkte mangel på udvindelsesmuligheder. Råstoffernes fordyrelse gennem 70-ernes første halvdel har givetvis været en medvirkende årsag ved inflationsraten.

II) En anden faktor, der givetvis er medvirkende ved inflationen er følgende: De markedsdominerende virksomheder indenfor en branche kan kompensere for værdiforringelser af den konstante kapital gennem prisforhøjelser. Værdiforringelsen sker gennem forældelse af en given produktionsteknik (moralsk værdiforringelse), når en mere produktiv teknik bringes på markedet. Når den nye teknik har nået en sådan udbredelse, at dens produktivitets-forøgende virkninger begynder at påvirke udbuddet i en eller flere brancher, så vil den afgørende bestemme markedsværdiniveauet (ved at sænke det) og dermed bestemme mængden af det samfundsmæssigt nødvendige arbejde, der indgår ved produktionen af produktet. Den gamle teknik må så enten udskiftes omgående eller dens anskaffelsesværdi, der ikke længere kan reproduceres gennem salget af produktet til den nye markedsværdi fordi dens omkostningspris er for lav til formidle de gamle produktionsmidlers værdi over et givet (kort) tidsrum, må blive en delvis negativ post på virksomhedens regnskab, altså et aftræk i profitmassen.

Værdiforringelsen af den konstante kapital kan også ske ved at efterspørgslen falder og den påfølgende indskrænkning i udbuddet gennem en indskrænkning af den enkelte virksomheds produktion medfører, at den realiserbare produktværdi ikke kan formidle den til reproduktionen af den konstante kapital nødvendige værdimasse.

Det første tilfælde er der næppe nogen løsning på for den individuelle kapital eller for branchekapitalen i det hele taget.

Det andet tilfælde indebærer løsningsmuligheder, hvis produktionskoefficienterne er tilstrækkeligt fleksible således at en del af den konstante kapital kan omlægges til anden produktion.

Generelt vil virksomhederne imødegå denne situation ved at bremse produktmængden eller ved at sænke priserne alt efter de konkurrencebetingelser der handles under. I brancher med få og dominerende firmaer vil det nok være en indskrænkning af produktmængden ved stabile eler stigende priser, der vælges. I brancher med stærk konkurrence vil priskrigen nok blive resultatet. ${ }^{79}$ Problemet

79. Wygodski: Der gegenwärtige Kapitalismus. Pahl Rugenstein, 1972. 
er her, hvilke grænser der findes for prisfastsættelse med henblik på realiseringen af en værdimasse, der dækker værdiforringelsen af den konstante kapital ind? ${ }^{80}$

Wygodski har underkastet konkurrencepolitikken hos de store firmaer en grundig undersøgelse og finder, at overvindelsen af værdiforringelser sker gennem indefrysningen af produktivitetsfremmende teknik, således at markedsværdiniveauet holdes tilstrækkeligt højt til at ekstraprofitmassen kan dække værdiforringelsen. Men denne løsning indebærer for det første, at de store firmaer indenfor og mellem brancherne ikke lader det mulige produktivitetsniveau blive til virkelighed, men finder dets virkeliggørelse hos mindre firmaer og kvæler det gennem indlemmelse. ${ }^{81}$ For det andet indebærer det, at der findes svære forhindringer for tilgang til branchen for fremmed kapital.

Problematikken her kan ikke løses gennem en henvisning til en stigende efterspørgsel på branchen, fordi stigende efterspørgsel ikke er en faktor, der primært er afhængig af branchen selv. Om virksomheden eller branchekapitalen derimod er herre over udbuddet afhænger af mange faktorer: råstofleverancernes strukturering spiller en rolle, produktivitetsniveauet er også afgørende. Kan leverancerne monopoliseres og er produktivitetsniveau og know-how-niveau så højt, at minimumsgrænsen for kapitalanlæg ligger i toppen, og er markedet vanskeligt tilgængeligt for nye produkter, så vil en prispolitik, der udspringer af en kunsig begrænsning af udbuddet være mulig, og således at der i markedsværdiniveauet er indbygget en ekstraprofitmasse, der er stor nok til at dække en gennemsnitsprofit eller en overgennemsnitslig profit plus værdiforringelsen. Men alene niveauet for den organiske kapitalsammensætning indebærer her, at markedsværdiniveauet ikke kan være dækket ind af produceret værdi, - hvilket derimod er Wygodskis tese. Der er nemlig også her tale om realiseringen af »falsk social værdi« i form af ekstraprofitter, og problemet om reproduktionen af den moralske værdiforringelse gennem salg ved et givet markedsværdiniveau er egentligt kun spørgsmålet om fordelingen af ekstraprofitten på forskellige poster, (og mere eller mindre af hensyn til de forskellige fradragsregler - hvis vi ser helt konkret på det).

Sagen er vel nok den, at udbudsbegrænsningen m.h. på opnåelse af et markedsværdiniveau, der gør meget store ekstraprofitter mulige, er en balanceakt, hvor overbalancen udgøres af et profitniveau, hvis størrelse får store kapitaler fra andre brancher til faktisk at vove springet og pelsen og søge ind i den pågældende branche alle risiki til trods.

Konklusionen må nok her blive, at den moralske værdiforringelse er aktuel i en mulig eller faktisk konkurrencesituation: den »mulige « konkurrencesituation er en relation mellem meget store firmaer indenfor en branche eller fra branche til branche, hvor de pågældende firmaer råder over største delen af

80. Altvater, Hoffmann, Künzel og Semmler: Inflation und Krise der Kapitalverwertung, Prokla nr. $17 / 18,1975$, s. $262-265$.

81. Wygodski, bd. kap. III. 
markedsandelen. Her vil tendensen kunne gå i retning af en borgfred, hvor man ikke konkurrerer på pris, men holder markedsværdiniveauet stabilt gennem en nedfrysning af de udbudsskabende innovationer. Man kører altså bevidst på underkapacitet. Men det betyder selvfølgelig ikke, at man nedfryser omkostningssænkende innovationer, men man fortsætter her den indbyrdes konkurrence, dog blot således, at de faktiske omkostningssænkninger ikke kan »ses« på markedsværdiniveauet, altså har en ren ekstraprofitmaksimerende effekt.

Den »faktiske« konkurrencesituation er en relation mellem store og små firmaer eller mellem små firmaer indenfor en branche. De mindre firmaer anvender teknikken til at sænke priserne (gennem forøget udbud) - om de så har udviklet teknikken selv eller ej. De helt store firmaer derimod kan i kraft af deres markedsandel og enorme kapacitet hurtigt vinde en eventuelt priskrig og herefter igen stabilisere markedsværdiniveauet på dets tidligere højde (eller endnu højere). Resultatet er dog her, at markedsværdiniveauet kan blive presset længere ned, hvis de mindre firmaer ikke er tilfreds med deres markedsandel og selv vil have ekstraprofitter, men grænsen for sænkningen af markedsværdiniveauet er sat af gennemsnitsprofitten plus værdiforringelsens omslagsprocent. Herigennem sløves konkurrencen, og branchens prisniveau bliver overgennemsnitsligt. Et forhold, der alt efter udbud-efterspørgselskonstellationen vil trække yderligere kapitaler til. Resultatet af de mulige foranstaltninger mod værdiforringelse af den konstante kapital gennem udbudsbegrænsede foranstaltninger er altså afhængig af udbud-efterspørgselsmekanismen, og af de specifikke forhindringer for kapitaltilførsel - der aldrig kan være institutionelle indenfor industrien. Men ved en efterspørgselsovervægt vil værdiforringelsesforholdet kunne presse markedsværdiniveauet yderligere op, fordi dette skal dække både en gennemsnitsprofit, ekstraprofit (for visse firmaers vedkommende) plus en del til reproduktion af værdiforringelsen. Forholdet forstærker altså den skabelse af »falsk social værdi« som statens efterspørgselsskabende interventionsaktivitet medførte. Men her gælder, at for at tale om »værdiforringelse « af konstant kapital kræves en »faktisk « konkurrencesituation, der kan indføre et lavere gennemsnit for værdien, der altså kan sænke den portion samfundsmæssigt nødvendigt arbeje, der indgår i varens produktion. Det kan kun effektueres gennem kvantitative og kvalitative ændringer i udbud og produktionsmetoder. Disse ændringer behøver dog ikke påvirke markedsværdiniveauet for at de kan have værdiforringende effekt, fordi de kan betinge uacceptable niveauforskelle i ekstraprofitter hos de store firmaer.

III) Hvilken rolle pengeformen og dermed kreditten spiller for prisniveauet og dermed for inflationen (og primært for skabelsen af gennemsnitsprofitraten) skal undersøges i del II.

Der er nu teoretisk og empirisk åbnet op for en placering af statsinterventionens virkningssammenhæng i form af efterspørgsel til sektor III i det reproduktive kredsløb under kapitalismens betingelser. Det bliver da muligt at stille det 
spørgsmål systematisk, hvordan statens efterspørgsel opstår, fungerer, altså indvirker på den kapitalistiske $\varnothing$ konomi, som den tegnes af modsigelserne mellem enkelt- og totalkapital, og hermed stille denne artikels hovedspørgsmål: hvad er grænserne for statsinterventionen, i dens subjektive og objektive aspekt?

Svaret er her, at staten gennem sin efterspørgselsskabende aktion blokerer for dannelsen af produktionspriser i hele samfundet og dermed sætter sig i modsætning til kapitalens begreb: at afkaste så meget værdi som muligt proportionalt med sin størrelse.

Pointen er da, at gennemsnitsprofitraten ikke altid kan skabes gennem kapitaloverførsler, bl.a. p.g.a. kapitalens træghed, når den findes $i$ form af fast kapital. Alternativet er her, at profitrateudligningen mellem alle brancher så fordres af kapitalgrupperne i de forfordelte brancher ad politisk vej. Da kapitalens organisationer herhjemme opfatter for nøje statsstøtte som nedbrydelse af de liberalistiske principper, så kan profitrateudligningen kun ske ad negativ vej: gennem en standsning af den aktivitet, der giver nogle sektorer og brancher et overgennemsnitsligt profitrateniveau. Kort sagt gennem stop for efterspørgslen til sektor III.

Sådan skal byggestoppet bl.a. også forstås. 


\section{Del II: Uddybning af konkurrencens niveau}

\section{Kapitel 4}

\section{Kapitalens formspecificeringer og reproduktionsske- maerne}

I denne del skal følgende forhold undersøges: Statens eferspørgsels- og udbudsskabende mekanismer med henblik på dannelsen af gennemsnitsprofitraten. Der argumenteres for det forhold, at prisniveauet i industrien er afgrænset af gennemsnitsprofitraten, der på sin side er båret af det gennemsnitlige profitniveau indenfor brancherne på de varer, hvis individuelle værdi svarer til markedsværdierne.

Det bliver på baggrund af dette perspektiv ikke muligt, at få store firmaer i højt mekaniserede brancher (brancher med meget høj grænse for minimumsanlæg) kan sætte deres prisniveau vilkårligt over længere tid. Således kan enhver voluntarisk »cost-push «-teori på forhånd afvises. ${ }^{1}$

Prisniveauet er begrænset opefter af gennemsnitsprofitraten i de andre brancher, hvilket indebærer, at et permanent eller blot relativt langvarigt overgennemsnitligt ekstraprofitniveau i en branche vil fremkalde investeringspres på denne branche, et pres, der p.gr. af kredittens elasticitet og gigantiske rammer ikke engang er begrænset af den skyhøje nedre grænse for anlæg af kapital i visse brancher. Focuseres skal statens medvirken ved dannelsen af gennemsnitsprofitraten, ikke alene som det i foregående kapitel er blevet belyst - i egenskab af en instans, der skaber et højt markedsværdiniveau og dermed store ekstraprofitter - men også som en instans, der direkte gennem egne investeringer og investeringssubsidier og indirekte gennem sin udvikling af teknik og videnskab (det sidste aspekt skal dog ikke tages op her) påvirker udbuddets kvalitet og kvantitet og dermed dannelsen af et alment prisniveau (produktionspriserne) og af gennemsnitsprofitraten. En nærmere bestemmelse af begrebet for totalreproduktionen er også nødvendig, og det sker gennem en samtænkning af konkurrencens begreb og reproduktionsskemaerne. ${ }^{2}$

1. En god beskrivelse af cost-push og demand-pull effekterne findes hos Olaf E. Dombrowsky: Zur Kritik bürgerlicher Infla tionstheorien, Prokla, nr. 17/18, 1975.

2. Et af de første forsøg herpå er Grossmanns i Die Wert-Preis-Transformation bei Marx und das Krisenproblem, trykt i Aufsätze zur Krisen theorie, Archiv sozialistischer Literatur, nr. 20, Frankfurt, 1971. Artiklens løsning på problemer - der er koncentreret omkring en kritik af Rosa Luxemburg - ligger dog relativt fjernt fra det løsningsforsøg, der oprulles her. 
Endelig skal dannelsen af interesser i samfundet belyses ud fra den differentiering i revenukilde-begrebet som kapitalens form-specificeringer på niveauet for kapitalen-i-dens-realitet skaber, altså ud fra forskellen mellem handels- og penge- og rentekapitalens rolle i totalreproduktionsprocessen. ${ }^{3}$ For en metodisk behandling af disse emner er en række ekskurser nødvendige - der er altså ikke blot tale om sidespring fra den egentlige fremstilling, men om væsentlige momenter til opbygningen af vores konklusion.

$\mathrm{Da}$ industrikapitalens formbestemmelser på niveauet-for-kapitalen-idens-realitet er blevet gennemgået i første del, er det rimeligt at tage fat på de andre kapital-former.

\subsection{Handelskapitalen og gennemsnitsprofitraten}

Det kapitalistiske samfund kendetegnes af distinktionen mellem produktionssfære og cirkulationssfære: dette kommer til udtryk som en mulig og ofte faktisk variation mellem varernes individuelle og samfundsmæssigt nødvendige indhold af abstrakt arbejde (værdi). Denne variation formidles gennem bremsningen eller blokeringen af varekredsløbet:

$$
\mathrm{P}-\mathrm{V}<\text { produktionsm. } \text { - Produktionsproces - V' - P', }
$$

således at bevægelsen V' - P' ikke kan foregå. Der opstår da ofte en kompenserende bevægelse, der går ud på, at $\mathrm{P}$ forringes i forhold til den faktiske værdi af V'. Metamorfosen V' - P' får da en meget central rolle i kapitalismen. Det er gennem den at den producerede produktionsværdi realiseres uden en indskrænkning af værdiproduktet, dvs. således at gennemsnitsprofitraten kan realiseres gennem varesalget.

I den udviklede kapitalisme kan en særlig form for kapital udskilles til at varetage realiseringens funktion. ${ }^{4}$ Denne type kapital kaldes handelskapital (HK). Den afkaster ifølge sit væsen (qua kapital) profit på lige fod med de andre kapitaler i produktionssfæren, men da den tilhører cirkulationssfæren er den ikke selv med til at skabe det værdiprodukt, hvoraf profitten på totalsamfundsmæssigt plan skal tages. HK's aktivitet er bundet til pengekapitalens kredsløb og ser således ud: P-V-P'. ${ }^{5}$ De penge handelskapitalisten fremskyder må - ud fra tesen om en identitet mellem værdi og pris, der sætter sig igennem på totalplan og i tiden via cyklen - rent systematisk betragtet som en del af industrikapitalens (IK) værdiprodukt.

3. De illusioner, der udspringer omkring jordrenten, og som rubriceres under den trinitariske formel på linie med illusionerne omkring lønarbejde og kapital er ikke taget med her, bl.a. fordi de ikke spiller så stor en rolle ved forståelsen af statsintervention.

4. Denne kapitalform er for $\emptyset$ vrigt den genetisk første, mens den naturligvis logisk set er afhængig af industrikapitalen, hvor jo værdiproduktionens begreb betemmes.

5. Das Kapital, bd. III, s. 280. Se desuden Das Kapital, bd. III, kap. 16, 17 og 18. 
I IK's bevægelser indtræder HK via halv-metamorfosen P-V, og har således gennem den akt ikke gennemført varemetamorfosens hele gennemløb, dvs. at kun besidderen af vareproduktet har skiftet, mens vareproduktet selv ikke har gennemgået en formforvandling (til konsumtiv form). ${ }^{6}$

På niveauet-for-kapital-i-almenhed betragtes HK som uproduktiv, idet der pr. definition ikke kan skabes værdi i cirkulationssfæren, fordi arbejdet dér ikke har status af »konkret arbejde«, dvs. ikke er nødvendigt for at produktet kan få sin konsumerbare form. (Realiseringen af konsumtionens mulighed, ikke af dens virkelighed.) Således opfatter Marx f.eks. transportarbejde som produktivt arbejde, men ikke ekspeditionsarbejde i engros- og detailhandel. ${ }^{7}$

HK's fixe og cirkulerende kapital tærer altså ikke alene på det totale værdiprodukt i samfundet, men også på dettes stoflige side: den tærer på fonden af de »reproduktive « varer. ${ }^{8}$ HK består af tre typer kapitalanlæg:

a) HK til køb af IK's vareprodukt.

b) HK's faste kapitalanlæg (lagerbygninger, kontorer, etc.)

c) HK's lønarbejde. (Regning, bogføring, spedition, markedsføring, etc.) Salgsprisen for HK's vareprodukt, dets produktværdi, bliver da: $a+b+c+$ $(a+b+c+) \times$ gennemsnitsprofitraten).

Både $\mathrm{a}, \mathrm{b}$ og c plus profitten på dem er stoflige og værdimæssige størrelser, der er skabt af IK og blot nominelt overtaget af HK m.h. på tilegnelse af en del af totalmerværdien.

Efter hvilke kriterier, gennem hvilke form-bestemmelser, fordeles nu totalmerværdien skabt af IK på henholdsvis IK og HK? Marx’ tese om dannelsen af gennemsnitsprofitraten må her modificeres derhen - hvilket han eksplicit fremhæver - at varerne realiseres til deres markedsværdier (HK's salgspris), at varerne altså realiseres til produktionspriser på totalplan. Dette indebærer, at IK's vareprodukt afhændes til en pris, der ligger under produktets markedsværdi (produktionspris). HK's profit indgår m.a.o. i dannelsen af produktionspriser, fordi HK's profit indgår i dannelsen af gennemsnitsprofitraten. ${ }^{9}$

Begrebet for dannelsen af gennemsnitsprofitraten giver tydelig en anvisning på hvilket omfang HK kan tage i forhold til den totale reproduktion: HK kan nemlig ikke overstige en sådan størrelse, at den tager en større profit hjem end IK. Dette ville nemlig betyde en kapitalflugt fra IK til HK. (Hvis omvendt så omvendt).

At HK's totalomfang bestemmer dens andel i gennemsnitsprofitraten er let at se: ${ }^{10}$ Totalkapitalen $(\mathrm{IK}+\mathrm{HK})=1000$. Heraf er $\mathrm{IK}=900$ og $\mathrm{HK}=100$.

6. Her menes både produktiv og privat konsumtion.

7. Om »produktivt« versus »uproduktivt« arbejde se bl.a.: Theorien über den Mehrwert, bd. I, kap. 3 plus bilagene, samt Resultate des unmittelbaren Produktionsprozesses, Archiv sozialistischer Literatur, 17, Frankfurt, 1969, s. 64-74.

8. »Reproduktive varer« er varer, der er produceret i sektor I eller II, altså varer, der indgår som komponenter i den faste eller cirkulerende kapital.

9. Das Kapital, bd. III, s. 295-296.

10. ibd. s. 296-297. 
For IK er m' $=100 \%$, og v $=180, \mathrm{k}=720$. Merværdien hos $\mathrm{IK}$ er da $=180$. Disse 180 udgør samfundets totale værdiprodukt og skal deles mellem IK og HK proportionalt med deres størrelse. Da HK udgør 1/10 af totalkapitalen har den ret til $1 / 10$ af totalmerværdien $=18$. HK's p' bliver da $18 \%$. IK's profit er $9 / 10$ af $180=162$. P' er da som ved $\mathrm{HK}=18 \%$.

Havde HK været større i forhold til totalkapitalen ville dens p' have overgået IK's.

IK sælger sine varer til HK for 720k $+180 v+162 p=1062$. HK sælger dem videre med en profit på $18 \%$ af sin egenkapital $=100$, dvs. for $1062+18=$ 1080. Denne pris er varens produktionspris.

Marx slutter heraf, at HK's eksistens sænker produktionsprisen: merværdi 180 giver i forhold til en kapital på 900 20\% i gennemsnitsprofitrate, mens den i forhold til en kapital på 1000 kun giver 18\% i gennemsnitsprofit, og da produktionspriserne defineres som omkostningsprisen + omkostningsprisen multipliceret med gennemsnitsprofitraten, vil disse falde ved stigende HK og konstant værdiprodukt hos IK.

Heraf kan man bl.a. slutte følgende:

En sænkning af produktionspriserne betyder ikke en sænkning af markedsværdien, men blot en indskrænkning af IK's profit proportionalt med total-HK's størrelse, m.a.o. en sænkning af de priser HK betaler IK for dens vareprodukt.

Der er m.a.o. tale om en - fra enkeltkapitalside betragtet - åbenlys modsætning mellem IK's og HK's interesser.

Ifølge Marx har HK dog også gunstige virkninger på totalkapitalens omslag, fordi realiseringen af produktionsværdien overgår til en funktionalistisk instans, hvorved den totale kapital, der er involveret i realiseringen, vil kunne begrænses. Graden af HK's positive og negative virkninger på IK er altså bestemt af dens indvirkning på omslagshastigheden, der selvfølgelig til en vis grad er omvendt proportional med HK's størrelse (jo hurtigere omslag, jo mindre HK), i alt fald hvad angår post a), nemlig HK's udlæg til køb af IK's vareprodukt. ${ }^{11}$ Jo større en relativ del HK udgør i et samfund desto vanskeligere bliver det for produktivitetsstigninger at resultere $i$ et fald i produktionspriserne. Dels fordi HK's profit belaster IK's profitrate og forhindrer en reduktion af markedsværdiniveauet gennem udbudsforøgelse med samtidig prissænkelse, dels fordi HK's omfang og kvalitet medvirker til at selv de mindst produktive kapitaler kan få realiseret deres produktværdi, og dermed opretholde eksistensen.

Jo større anlæg til fix og cirkulerende kapital fra HK's side, desto større efterspørgsel i samfundet, fordi HK jo ikke selv skaber et vareprodukt, hvis form kunne bevirke, at det indgik reproduktivt i samfundet. HK indvirker da indirekte - da dens reproduktion og akkumulation begrænser den totale

11. ibd. s. 298 og s. 326 . 
reproduktions- og akkumulationsfond - til at forøge efterspørgslen len på SI- og SII-varer og dermed til at få markedsværdiniveauet til at stige.

En stor HK Indenfor et samfund medvirker da alt i alt - dens positive virkninger, der jo går ud på at den gennem en forøgelse af omslaget kan medvirke til en forøget merværdiproduktion, til trods - til at forværre dettes stilling på verdensmarkedet ved at forh øje dets produktionsprisniveau. ${ }^{12}$

Men en bedømmelse af HK's negative virkninger er bundet til muligheden for at afgøre størrelsen af realiseringsomkostningerne, hvis realiseringsfunktion blev varetaget af IK selv, og til muligheden for at afgøre HK's faktiske indvirkninger på omslagshastigheden, størrelser, der p.gr. af deres abstrakte karakter er vanskelig at arbejde med. Dertil kommer at markedsføringsmekanismernes store rolle i senkapitalismen for efterspørgslens opretholdelse kan give belæg for det kapitalrationelle i en relativt større HK end tilfældet var på Marx' tid. Men et er i hvert fald sikkert: HK's interesser er på totalplan entydigt bundet til IK's valoriseringsbetingelser, selvom det for den enkelte industri- og handelskapitalist ikke tager sig sådan ud.

Ser vi på den trinitariske formel, så er det tydeligt, at bevidstheden hos de to kapitalfraktioner, der udspringer af kapitalens formbestemmelse som henholdsvis IK og HK på niveauet-for-kapitalen-i-dens-realitet, umuliggør, at kapitalen opfattes som et ensidigt bestemt subjekt, der blot har den egenskab at afkaste profit proportionalt med sin størrelse. For profitten på IK er til en vis grad omvendt proportionalt med HK's størrelse (hvilket også - som vi skal se - er tilfældet med pengekapital og rentekapital).

At staten heller ikke betragter disse to kapitaltyper som ligestillede revenukilder viser bl.a. nationalbankens inddragelse af tilladelser til lån i udlandet m.h. på driftskreditter. ${ }^{13}$

For HK vil profitten naturligvis være omvendt proportional med det beløb der gives for en given masse varer fra IK. Profitten fremstår da snarere som resultatet af handelstalent, og HK som »produktiv«, end som et fast afkast på en given kapitalmasse proportionalt med dens størrelse. Men naturligvis fremstår profitten her også som »kapitalens frugt« og profitten som proportional med kapitalens størrelse, hvilket i forbindelse med HK sætter sig således igennem, at stigende kapitalmasse muliggør lavere produktværdi, simpelthen fordi omslagets hastigere tempo muliggør et større udbud. Men sådanne virkninger af stigende HK er ikke nødvendige, sammenhængene er derimod komplicerede og skal ikke bekandles yderligere her.

12. En intensivering af arbejdet under Handelskapitalen vil forøge kapitalens omslag på totalsamfundsmæssigt plan og dermed gøre et større værdiprodukt muligt. Samtidig muliggøres dog en udvidelse af Handelskapitalen, hvis indvirkning på gennemsnitsprofitraten vil være afhængig af stigningerne i Handelskapitalen i forhold til stigningerne i totalmerværdien. Se også Das Kapital, bd. III, s. 305-306 og s. 325-326.

13. Danmarks Nationalbank, beretning og regnskab, 1974, s. 81 . 
Hvilke bevidsthedsformer HK giver anledning til er afhængig af det anskuende og agerende subjekts interesser, men differentieringen skulle blot fastslås.

\subsection{Kreditten og gennemsnitsprofitraten}

Til en forståelse af det objektive grundlag for dannelsen af gennemsnitsprofitraten, af formerne for statens integration med totalkapitalen og for en konkretere bestemmelse af de illusioner, som følger af kapitalens formbestemmelser på et konkretere niveau, er en behandling af kreditten nødvendig. Det niveau hvorpå kreditten skal afledes er både niveauet-for-kapital-i-almenhed og niveauet-for-kapitalen-i-dens-realitet. På niveauet-for-kapital-i-almenhed skal kreditten bestemmes ud fra den mulige bremsning eller blokering af varekapitalens metamorfose:

Kreditten skal her udledes af de følgende faktorer:

a) Pengenes funktion i cirkulationssfæren som på en gang kvantitativt udtryk for værdi (Mass der Werte) og pris-indeks (Massstab der Preise). I denne dobbeltfunktion ligger muligheden for inkonkurrens mellem værdi- og prisudtryk nemlig. ${ }^{14}$

b) oplagring af penge i form af skat (Schatz). Denne form må dog ikke sammenblandes med opbevaringen af likvide midler i kapitalismen, dvs. må ikke - som Keynes gør det i sit begreb »hoarding « - forveksles med pengenes funktioner i rentekapitalens form.

c) pengenes funktion som betalingsmiddel (Zahlungsmittel). Heri ligger den mulige adskillelse af varekapitalens kredsløb, således af varen er afhændet på et tidspunkt, hvor den endnu ikke er forvandlet til pengeform.

På niveauet-for-kapitalen-i-dens-realitet skal kreditten bestemmes ud fra følgende to funktioner:

A) Pengekapital i egenskab af akkumulationsfond.

B) Akkumulationsfondens størrelse i relation til akkumulationsbehovet under konkurrencens betingelser. ${ }^{15}$

Ad a) Dette punkt er den systematiske indfaldsvinkel til udledningen af papirpengene. Heri ligger den formmæssige mulighed for et brud i værdi og prisidentiteten over et vist tidsrum og på visse planer.

Men da kredittens hele væsen bestemmes på grundlag af værdiprisidentiteten - det viser Marx' overvejelser i kap. 17 af bd. II af Das Kapital, hvor akkumulationsfonden tænkes som kredittens grænser-kan værdipris-inkongruensen ikke være det bærende element i en bestemmelse af kredittens funktionsmåder. Således må man slutte, at selvom Bretton-Woods-aftalerne har ændret

14. Zur Kritik der politischen Ökonomie, Dietz Verlag, Berlin 1970, s. 67-68.

15. Theorien über den Mehrwert, bd. III, s. 508. 
begreberne for valutaernes gulddækning, så er det afgørende for valutaernes stilling stadig faktorer, hvis væsen udgøres af værdien, (se også forrige del).

Det betyder at værdi-pris-identiteten er dynamisk og sætter sig igennem ad mange veje, her især det forhold, at valutaternes købekraft er direkte proportionale med arbejdets produktivitet $\mathrm{i}$ den pågældende nation, men omvendt proportionale med produktionsprisniveauet.

Det er først og fremmest gennem handels- og betalingsbalancen, at værdipris-identiteten på nationalt og dermed internationalt plan gennemtvinges, fordi en kunstig skabt efterspørgsel f.eks. giver dækningsløs kreditudvidelse (»demand-pull-fænomenet), eller fordi en udvidelse af prisniveauet på SI- og/ eller SII-varer skruer produktionsprisniveauet yderligere op (»cost-push-fænomenet«), og følgelig kræver udvidelse af cirkulationsmassen.

Marx' tese om identiteten mellem værdi og pris er utænkelig uden det dynamiske aspekt som cyklus-begrebet bringer ind. Den er en dynamisk »lov«, der virker således, at den naturligvis ikke umuliggør en inkongruens mellem værdi og pris, men at den gennem virkningerne på totalproduktionen af en sådan inkongruens sætter rammer for dens mulige omfang. Således sætter identiteten af værdi-pris sig igennem i det stigende betalingsbalanceunderskud, hvor den i 30'erne satte sig igennem i en generel overproduktion, altså i en virkelig krise.

Den dynamiske identitet af værdi pris viser sig således idag i kravet om en bremsning af den offentlige og private konsumtion af hensyn til betalingsbalancen og til valutaens stilling. (For hvis der ikke var en dynamisk identitet mellem værdi og pris, så behøvede man jo ikke låne penge i udlandet, men kunne bare trykke dem selv). Således repræsenterer akkumulationen et værdiprodukt også når den muliggøres af penge hentet gennem lån i udlandske banker.

Ad b) Skat (Schatz) spiller idag ingen rolle for skabelsen af kreditfonden, fordi den er afløst af sine spejlbilleder i kapitalformen: penge- og rentekapital. I et kapitalistisk samfund kan penge ikke lægges til side som penge, fordi manglende merværdiafkast er det samme som tab.

Ad c) Pengenes funktion som betalingsmiddel er meget centralt, fordi det muliggør adskillelsen af køb og salg. I Theorien über den Mehrwert siger Marx om kapitalens funktioner i kredsløbet i egenskab af penge som betalingsmiddel: »Krisernes almene mulighed er kapitalens egen formmæssige forvandling, det at $\mathrm{k} \emptyset \mathrm{b}$ og salg tids- og rummæssigt falder fra hinanden. $\ll^{16}$

Ad A) og B). I konkurrencen, hvor et givet markedsværdiniveau indenfor en branche, gennem de stoflige produktionsbetingelser det afspejler, sætter en minimumsgrænse for kapitalanlæg ved gennemsnitsprofit, vil kreditten spille en enorm rolle, fordi det er den, der gør akkumulationen uden akkumulationsfond mulig og dermed styrer de former hvorunder udbuddet kan udfoldes. Som sådan er kreditten en central faktor ved etableringen af gennemsnitsprofitraten

16. ibd. bd. II, s. 515. Min oversættelse, OFK. 
og produktionspriserne. Kreditten kan kun mangelfuldt udledes på niveauetfor-kapital-i-almenhed, fordi der dér nok findes begrebet for en akkumulationstvang, nemlig den, der kommer til udtryk i overgangen fra den absolutte til den relative merværdi og afspejler kapitalklassens reaktion mod det stignde lønniveau p.gr. af stigende beskæftigelse, en reaktion der kommer til udtryk i investering i fix kapital, men hvor det dog kun er forholdet mellem konstant og variabel kapital og mellem kapitalist- og arbejderklasse, der indeholder akkumulationstvangen, ikke forholdet mellem enkeltkapitalerne, hvor kapitalens væsen fuldendes. På konkurrencens niveau derimod (niveauet-for-kapitalen-idens-realitet) bestemmes akkumulationstvangen gennem markedsværdiniveauet: når det synker, stiger minimumsgrænsen for kapitalanlæg ved mindsteprofit og følgelig stiger behovet for en kredit, der ikke er begrænset af akkumulationsfondens rammer. (Akkumulationsfonden er den del af merværdien, der ikke konsumeres eller går til andre formål). Dette skyldes, at en række små og mindre kapitaler ikke realiserer profit nok til at have en akkumulationsfond i det hele taget. Kreditten i egenskab af en centralisering, fordeling og forøgelse af akkumuleret pengekapital til produktive formål spiller en enorm rolle for reproduktionens simple og udvidede former, fordi det er den, der gør bevarelsen af alle de mindre firmaer mulig gennem en stabilisering af udbuddet og gennem en muliggørelse af realiseringen af selv varer med en produktværdi, der ligger over det samfundsmæssigt nødvendige arbejde til denne vares produktion.

Kreditten gør også ekstraprofitterne mulige indenfor brancherne ved at formidle den omfordeling af akkumulationsfonderne, der gør den koncentration af kapital mulig, der alene kan virkeliggøre de helt store investeringer i kapitalanlæg. Hertil kommer desuden, at kapitalbevægelserne mellem brancherne, der jo gør gennemsnitsprofitraten mulig i det hele taget, er ganske afhængig af kreditten, fordi overflytningen af kapital fra en branche til en anden hvori profitniveauet er højere for større kapitaler f.eks. jo ikke kan ske før det oprindelige kapitalapparat er realiseret, hvilket kan være en meget langsommelig affære. Endelig er kreditten også en betingelse for den form for markedsføring, der karakteriserer hele typen af udbuds-efterspørgsel i senkapitalismen. Kredittens konkretere former kan afledes af henholdsvis vare- og pengeformen i kredsløbene:

I) Af vareformen følger den kommercielle kredit, leasing, vekselsystemet, kredit altså, der foregår uden mellemkomst af pengeformen.

II) Af pengeformen følger pengekapitalen, rentekapitalen, altså kreditformer, hvor kapital fremskydes som vare i egenskab af kapital. ${ }^{17}$

Disse former kan nok afledes også af varekapitalen, men det er først i pengeformen, at de får deres kapitalistiske form. Rente i form af naturalier er systematisk helt forskellig fra rente af kapital. Deres formfuldendelse er altså baseret

17. Das Kapital, bd. III, s. 416. 
på pengeformen. Marx anfører s. 496 af bd. III af Das Kapital, at kommerciel kredit ikke fuldkommen kan erstatte pengeformens kreditformer, fordi arbejdsløn og skat nøje er forbundet med pengeformen for i det hele taget at kunne eksistere, og fordi kun de færreste producenter kan sælge direkte til alle dem de er intresserede i at købe af.

Kreditten i pengeform og dermed pengekapital og rentekapital kan bestemmes ud fra følgende grundlag:

a) Akkumulationsfonds: fra egen fond $=$ selvfinancering, fra andres fonds $=$ rentekapital.

b) Revenuet. Både a) og b) formidles oftest via banker eller financeringsselskaber.

c) Vekseldiskontering, og salg af værdipapirer og faste værdier.

d) Lån i udlandet.

e) Statslån, eksportpræmier, financeringsstøtte, etc.

Punkterne c), d) og e) stammer altså ikke nødvendigvis fra merværdien, hvis vi anskuer en given nation som et lukket system. Men det er højst sandsynligt, at de lån der optages i udlandet er forsølvet merværdi skabt i dette land, og at de faste værdier er tidligere akkumuleret merværdi.

Det er nu væsentligt at stille sig spørgsmålet: hvilke rammer er der for kreditskabelsen, dvs. hvordan sådanne rammer - hvis de findes - sætter sig igennem?

Generelt må man sige: kreditskabelsen er begrænset til akkumulationsfonden for så vidt at den skal anvendes produktivt (som IK) og for så vidt at den skal erhverves på hjemmemarkedet og dér være udtryk for et forsølvet vareprodukt.

Tager vi derimod verdensmarkedet med i betragtning, er der kun den grænse for kredittens forøgelse, at den anvendes produktivt $i$ en vis rate, dvs. at den ikke anvendes til privat og offentlig konsumtion. Men da der er stærke politiske hindringer for begrænsninger i disse to former for konsumtion ud over en vis ramme, kan kreditten i det moderne kapitalistiske samfund simpelthen ikke begrænses til produktiv anvendelse alene.

Men selv om kreditten kun ville blive anvendt reproduktivt og til akkumulation, så ville der også være grænser for sådan en anvendelse, fordi de andre nationer ville finde midler til at vægre sig imod et eller flere landes forspring i produktivitet. Anvendes kreditten derimod ikke-reproduktivt eller skabes den ved midler på hjemmemarkedet, der får den til at overskride akkumulationsfonden dér, så har det - som vi skal se - alvorlige virkninger for samfundet som helhed og for den interventionistiske stat i særdeleshed.

Lad os tage det sidste tilfælde først: forøgelsen af kreditten på nationalt plan langt ud over akkumulationsfonden. Magdoff og Sweezy påpeger i en interessant artikel fra februar 1975 i Monthly Review de utallige måder, hvorpå de private banker i USA kan skabe det Marx kalder for »fiktiv kapital«. Det er kapital, der ikke udtrykker forsølvingen af et værdiprodukt, men derimod blot det formelle krav på en del af totalmerværdien, altså på delagtighed i 
gennemsnitsprofitraten. Selvom Magdoffs og Sweezys konklusioner ikke er de samme som mine kan de påvisninger glimrende illustrere formerne, hvorunder kreditten på nationalt plan kan sprænge akkumulationsfondens rammer. Langtidslån via udstedelse af aktier - siger Magdoff og Sweezy - erstattes idag i stor udstrækning af kortfristede lån i de private banker, og der skelnes ikke mellem anlægs- og driftkapital. Især fra 1960 til 1974 stiger de kortfristede lån og det med en langt højere vækstrate end den, der gælder for den »ikkefinancielle« aktivitet i samfundet. Også bankernes spekulation af profithensyn stiger enormt i 70'erne: garantisummen i statsobligationer til dækning af udlånene plus egenkapital er forsvindende lille og formindskes stadig i forhold til udlånet. 80\% af indlånene i bankerne i USA er udlånt, og op til 40\% af disse indlån er ikke »rigtige « indlån, men lån taget $\mathrm{i}$ andre banker for at skaffe kapital. Bankerne udsteder også sælgelige beviser på indlån for at få kapital, m.a.o.: kreditten skabes ved hjælp af kredit.

Denne udvikling har givetvis både at gøre med Nixonregimets forkærlighed for Friedmanns kvantitetsteoretiske teorier om betingelser for $\emptyset$ konomisk vækst, men er selvfølgelig også nært forbundet med de enorme udgifter til imperialismens financering. Noget lignende kan ikke påvises herhjemme ved gennemgang af Beretning og regnskab for Danmarks Nationalbank, 1974, man har her helt kreditten i tømme, men en relativ stigning i de kortfristede kreditter er tydelig, samtidig med en stigning i kreditten til engros- og detailhandel i forhold til industrien. Kreditten til engros- og detailhandel fra 1963 til 1973 ser således ud:

Engroshandel: kreditstigning med 61\%. Detailhandel: 106\%. Industriens kredittagning: 79\%. (Tallene er givetvis blevet accentueret af krisen efter 1974).

Et andet udtryk for stigning i driftskreditterne gives i oversigten over industriens forskellige typer af lån i Carl Erik Sørensens »Kreditmarkedet og industriens ekspansion $\ll{ }^{18}$ Her viser det sig at investeringerne stiger $231 \%$ fra 1958 til 1969, mens »bankgælden«, der i vid udstrækning udgør kortfristede kreditter, ${ }^{19}$ altså er driftskreditter, stiger $285 \%$ i samme tidsrum. Den langfristede gæld stiger her $606 \%$, mens »anden gæld «, der først og fremmest omfatter leverandørkreditter ${ }^{20}$ stiger med $152 \%$ og aktiekapitalen endelig stiger med $148 \%$ i samme tidsrum.

Det gælder desuden her, at bankgælden udgør en langt større del af aktiekapitalen i 1969 end i 1958:

\begin{tabular}{|c|c|c|c|}
\hline & 1958 & og & 1969 \\
\hline Bankgælden i \% af aktiekapitalen i: & $41 \%$ & & $65 \%$ \\
\hline Langfristet gæld i \% af aktiekapitalen: & $32 \%$ & & $91 \%$ \\
\hline Anden gæld i $\%$ af aktiekapitalen: & $337 \%$ & & $342 \%$ \\
\hline
\end{tabular}

18. Kreditmarkedet og industriens ekspansion, af Carl Erik Sørensen, udgivet af Den danske Landmandsbank, 1971, s. 245.

19. ibd. s. 43.

20. ibd. s. 38 . 
Selv om stigningen $\mathrm{i}$ »anden gæld « delvis skyldes stigningen i skibsværfternes gæld og udenlandske firmaers lån hos moderselskabet, så viser dette skema, at kreditterne spiller en større rolle i det $\varnothing$ konomiske liv, og at stigninger i bankkreditten har været større end stigningen i den kommercielle kredit i forhold til aktiekapitalen.

Lad os nu give en bestemmelse af de formspecificeringer kapitalen underkastes gennem kreditten:

\section{2.a. Pengekapitalen:}

Pengekapitalen er bestemt af cirkulationens indhold: formidlingen af pengekredsløbet:

$\mathrm{P}-\mathrm{V}<_{\text {produktionsmidler }}^{\text {arbejdskraft }}$...Produktionsproces... V' - P'.

Pengekapitalen (PK) er bestemt af den praktiske formidling af alle de transaktioner, hvori penge er involveret. PK realiserer en profit, der p.gr. af dens uproduktive karakter udgør et aftræk af merværdien. Dens forhold til gennemsnitsprofitraten er det samme som HK's og det er dens forhold til totalreproduktionen også: den kan formindske omslaget og følgelig gøre en for øget værdiproduktion mulig, ja måske under visse betingelser være med til at sænke produktionspriserne. Gennemsnitsprofitraten er dog generelt omvendt proportional med PK's størrelse. ${ }^{21}$

Bankvæsenet skal afledes af PK's formbestemmelser, men bankkapitalens egentlige rolle og virkning i totalreproduktionen er nøjere bestemt af rentekapitalen. Bankvæsenet spiller nemlig en stor rolle for kreditudvidelsen og her fremskyder bankerne ikke cirkulationsmidler, men derimod rentekapital. dvs. at en forøgelse af likviditeten sker i form af fremskudt rentekapital. Det samme sker, når nationalbanken gennem obligationsk $\varnothing \mathrm{b}$ for $\varnothing$ ger likviditeten: forretningen af obligationerne indebærer, at pengene er fremskudt som kapital. ${ }^{22}$

\section{2.b. Rentekapitalen:}

Rentekapitalen (RK) afledes af det samme kredsløb som PK og renten bestemmes som »kapitalens brugsværdi «, der jo består i at afkaste merværdi. ${ }^{23}$ Også i RK's form bliver kapitalen vare i egenskab af kapital, dens fetichering fuldendes. ${ }^{24}$ Renten bliver p.gr. af RK's uproduktive karakter en del af merværdien. RK forudsætter eksistensen af to typer kapitalister: kapitalejere og kapitalanvendere og på mange punkter er deres interesser i modsætning til hinanden.

21. Das Kapital bd. III, s. $451 \mathrm{ff}$.

22. Disse problemer berøres s. $546 \mathrm{ff}$ i bd. III af das Kapital.

23. Das Kapital, bd. III, s. 350ff.

24. Das Kapital, bd. III, s. $354 \mathrm{ff}$ og Theorien über den Mehrwert, bd. III, s. 445 ff. 
I afsnittet om revenukilderne i bd. III af Theorien über den Mehrwert og visse steder i bd. III af Das Kapital gør Marx en del ud af at fremhæve det forhold, at rentekapitalen bliver prototypen på kapital, således at kapitalanvenderen også betragter sin egen personligt investerede kapital i RK's form, således at han betragter sin profit som rente. Således vokser kapitalens værdiside afgørende sammen med den stoflige side, og får »værdi «, en ting, til at synes »produktiv«, tingsavlende. Med udviklingen af aktieselskabsformen og integration af kreditmarkedet er dette selvfølgelig rigtigt om kapitalens måde at »socialiseres « på, men det er forkert - som Marx gør - udelukkende at ville aflede kapitalismens mekaniske legitimationsbevis af RK's forhold til renten, sådan som det sker i den trinitariske formel, for den anvendte kapital har sine særlige illusioner der - som vi skal se - formes gennem konkurrencen: her synes profitten nemlig et produkt af kapitalsparsommelighed og ikke direkte et produkt af proportionelle kapitalstørrelser. Men de to illusionsformer udelukker selvfølgelig ikke hinanden.

Givetvis skal man dog i den trinitariske formel indarbejde modsætningen mellem IK og RK, der gør, at den enes profit er omvendt proportional med den andens, hvilket også på totalplan gælder forholdet til de respektive kapitalstørrelser.

Rentefoden er bestemt af følgende faktorer:

Rentefodens maximalgrænse er gennemsnitsprofitten - profit til den kapitalist, der anvender RK, eller løn til den person, der er ansvarlig for kapitalens produktive funktioner i det tilfælde, hvor den fungerende kapitalist kun har status af ansat. Rentefodens minimalgrænse er ubestemmelig, men at den ikke bliver så lav som man kunne tro har vist sig, når en statslig likviditetsforøgelse samtidig med faldende rente alligevel ikke har fået renten til at falde yderligere, fordi folk - med forventning om stigende rente - ikke har villet låne deres penge ud.

Ophævelsen af obligationsrationeringen i 1968 og kraftig likviditetsudpumpning fra nationalbankens side gennem obligationskøb i 1968 og begyndelsen af 1969, således at likviditeten forøgedes langt stærkere end nationalindkomsten, førte alligevel ikke til fald i renten..$^{25}$

Ifølge Marx er der heller ikke nogen direkte sammenhæng mellem pengemassen og rentefoden. ${ }^{26}$ Dog skal man her være forsigtig med at blande pengemasseforøgelsen (likviditetsfor øgelse) sammen med kreditforøgelse, fordi kreditten skaber andre former for udbudefterspørgselsstigninger end likviditetsforøgelse, der altid må forudsætte en akkumulation for at få nogen virkning.

På totalsamfundsmæssigt plan afgrænse gennemsnitsprofitraten altså rentefoden, mens rentefoden i sine nøjere bevægelser ikke behøver følge gennemsnitsprofitratens udsving, men her til dels er afhængig af en simpel udbud-efterspørgselsmekanisme på baggrund af de alternative muligheder for pengeanbringelse. Et stort obligationsmarked vil derfor kunne tvinge renten i vejret, det samme gælder et stort privat forbrug financeret gennem kreditgivning.

25. Kreditmarkedet og industriens ekspansion, ibd. s. 184.

26. Das Kapital, bd. III, s. $546 \mathrm{ff}$. 
Der er altså mange medspillende faktorer ved bestemmelsen af det analytiske grundlag for renteniveauet, bl.a. spiller politiske forhold ind heri: den ringe diskontonedsættelse til 9\% per 14-1-75 var bl.a. udtryk for nationalbankens interesse $\mathrm{i}$ at forhindre, at en lavere rente herhjemme end i udlandet ville få folk til at indfri deres lån dér og tage dem op herhjemme i stedet, hvilket ville dræne valutakassen og igen sætte renten op. Derfor kun en ubetydelig diskontonedsættelse.

Fastsættelse af rentemarginalen er en anden vej at regulere renteniveauet på. ${ }^{27}$ Hertil kommer udlånsaftalerne mellem de private banker og nationalbanken og udlånsloftet, samt valutabestemmelserne. Marx påpeger, hvordan renteniveauet følger cyklens bevægelser således, at renten topper i krisens brændpunkt, hvor behovet for likviditet bliver katastrofalt: men generelt gælder det i alt fald, at rentefoden ikke som markedsværdierne ved en given udbud-efterspørgsels-tilstand har et »naturligt « niveau. ${ }^{28}$

Hvor rentefoden altså kun følger gennemsnitsprofitraten således, at et højt renteniveau over længere tid $m a ̊$ have sin basis i et højt gennemsnitsprofitniveau, ${ }^{29}$ så afspejler rentefodens bevægelser derimod temmeligt nøjagtigt styrkeforholdet mellem to typer kapitalister: industri- og rentekapitalister. Derfor er der ingen selvfølgelig sammenhæng mellem en høj gennemsnitsprofitrate og store profitter til kapitalanvenderen, (Unternehmergewinn).

IK's profit er nemlig omvendt proportional med rentefodens højde. Derimod - siger Marx - griber RK ikke ind ved dannelsen af gennemsnitsprofitratens niveau, fordi der jo kun er tale om én kapital (værdistørrelse), der blot gennem transaktionerne mellem långiver (RK) og låntager (IK) skifter form.

RK indgår altså ikke som HK og PK (i bankers egenkapital) direkte i bestemmelsen af gennemsnitsprofitratens niveau, men klart nok indirekte, al den stund en meget lav profit til den fungerende kapitalist (Unternehmergewinn), vil mindske akkumulationen og dermed (under givne betingelser) værdiproduktionen i samfundet og således naturligvis gennemsnitsprofitraten, der jo på totalplan er forholdet mellem totalmerværdi og totalomkostningspris.

Den strengt systematiske forudsætning for at B kan låne kapital af A er, at B anvender denne kapital produktivt, at den anbringes således at den vil kunne afkaste merværdi. ${ }^{30}$ Anvender han den uproduktivt, altså til privat konsumtion, spekulation, etc., så vil den have samme virkning på gennemsnitsprofitraten som de negative virkninger af HK, idet den da udgør en merværdimasse, der har status af »materialiseret « krav på profit proportionalt med sin størrelse, men som ikke selv skaber værdi.

27. Lov om pengeinstitutters rentemarginal af 11-3-1975.

28. Das Kapital, bd. III, s. $372 \mathrm{ff}$.

29. Das Kapital, bd. III, s. 528.

30. Das Kapital, bd. III, s. 362. 
Således kan staten også - ved at opsuge dele af kreditmassen (nationalbanken sælger obligationer, sænker låneloftet eller strammer valutabestemmelserne; et eksempel på en kreditstramning er »Deponeringsaftalen« fra 1965 mellem nationalbanken og de private banker) - anvende den til produktive investeringer, f.eks. ved at låne den ud til investeringer i eksportindustrien på favorable vilkår, etc. Staten medvirker da til at bevare gennemsnitsprofitratens niveau. ${ }^{31}$ Anvender staten derimod kreditmassen som revenu, altså til efterspørgsel på SIII-varer, så vil virkningerne her være afhængige af hvorfra kreditmassen kommer. Kommer kreditten fra revenu beregnet på fremtidig konsumtion, så vil statens anvendelse af denne masse fungere som en overførsel af efterspørgslen fra nogle brancher eller sektorer til andre, og den vil da kunne stabilisere eller forhøje gennemsnitsprofitraten alt efter hvordan efterspørgslen virker på markedsværdiniveauet i de pågældende brancher.

Stammer kreditmassen derimod fra akkumulationsfonden, så vil statens konsumtive anvendelse af den begrænse den reproduktive produktmasse og skrue markedsværdiniveauet endnu højere op alt afhængig af akkumulationstempoet i SI og SII.

Men statens ekspropriering er ofte - f.eks. hvis det sker gennem udstedelse af statsobligationer - ikke nogen gratis ekspropriering, men kræver renteudgifter. Sådan »fiktiv kapital«, der blot har status af helt formelle krav på en andel af gennemsnitsprofitraten, men ikke har nogen forbindelse til de egentlige kapitalbevægelser (produktiv kapitalform) ${ }^{32}$, vil ligesom HK i dens negative virkning formindske gennemsnitsprofitraten ved at udgøre et krav på merværdi proportionalt med sin størrelse. Det ændrer intet ved den konklusion, at betalingen af renter af statsobligationer stammer fra fonds hentet via skatterne, fordi der her er tale om en faktisk formindskelse af merværdien. Af det foregående skulle det være tydeligt, at kredit aldrig med nødvendighed kan føre til dannelsen af IK, men er afhængig af gennemsnitsprofitrateniveauet og dermed af de stoflige betingelser for reproduktion i udvidet form på et givet tidspunkt indenfor brancherne. Der er ingen lineær kausalitet mellem forøgelse af kreditloftet og af omløbsmidlerne og så økonomisk vækst, fordi penge blot er en form, hvori kapitalen eksisterer. ${ }^{33}$ På den anden side er der idag en helt tydelig sammenhæng mellem et højt kreditloft og en udvidet likviditet og så den stigende efterspørgsel, der gennem stabiliseringen og forhøjelsen af markedsværdiniveauet fører til inflation.

Dette forhold har den borgerlige stats politikere og embedsmænd i vidt omfang indset, og heri ligger keynesianismens grænser indenfor det borgerlige samfund selv.

31. Om måder at skaffe yderligere kreditmasse på gennem en'rationalisering af kredsløbet, se: Das Kapital, bd. II s. 346 ff.

32. Das Kapital, bd. III, s. $482 \mathrm{ff}$.

33. Das Kapital, bd. III, s. 442. 


\subsection{Reproduktionsskemaerne, kreditten og gennemsnitsprofitraten}

For en dybere forståelse af gennemsnitsprofitratens dannelsesbetingelser gennem statens indvirken på økonomien er det endelig nødvendigt at tage Marx' reproduktionsskemaer op til en behandling m.h. på en bestemmelse af efterspørgslens rammer. Efterspørgslen er her begrænset af to faktorer: kreditten og akkumulationsraterne i de forskellige sektorer.

I det følgende skal jeg med udgangspunkt i Marx' fremstilling af betingelserne for »akkumulation og udvidet reproduktion « $\mathrm{i}$ kapitel 21 af bd. II af Das Kapital illustrere virkningerne af en tredie sektor i økonomien.

Denne sektor kan godt være byggeriet - som det er tilfældet i forrige del - men her bliver den produktion da delvis af produktiv karakter, fordi dele af den indgår i arbejdskraftens reproduktion (almennyttigt boligbyggeri, hospitaler, skoler) og i etableringen af transportbetingelser: broer, veje. (Hvis staten selv havde bygget disse ting, så ville de have været produktive i betydningen »reproduktive«, men næppe i betydningen »merværdiskabende $\ll)$.

Tager vi derimod en produktion som krigsproduktionen, så er der her ikke tale om en produktion med merværdiskabende eller reproducerende funktion.

I det følgende skal konklusionerne generelt drages m.h. på begge mulige indhold af SIII, altså at SIII både kan rumme en produktiv og en ikkeproduktiv produktion.

Marx understreger i afsnit I af bd. II af Das Kapital, at det kredsløb hvorudfra reproduktionen skal anskues hverken er pengekapitalens eller den produktive kapitals kredsløb, men derimod varekapitalens, fordi denne (varekapitalen) både leverer produkter til den produktive og den private konsumtion: Kredsløbet ser således ud: ${ }^{34}$

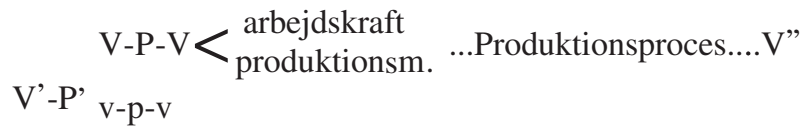

Det fors $\varnothing l v e d e$ vareprodukt kan altså anvendes i det »store« (reproduktive) eller $»$ lille« konsumtive) kredsløb.

Heraf følger, at akkumulationsfonden alene kan tages af merværdien i SI og SII, da disse sektorer alene skaber et produkt, der har reproduktiv form (form af $k$ eller $v$ ), således må SIII tage hele sin kapital (både til simpel og udvidet reproduktion (akkumulation) af SI' og SII's merprodukt. ${ }^{35}$

Udvidet reproduktion i forbindelse med en tre-sektor-model ser således ud, hvis det forudsættes at hele merværdien akkumuleres (at der altså ikke er no-

34. Das Kapital, bd. II, s. 99.

35. Cogoy formulerer dette s. 155 i artiklen Werttheorie und Staatsausgaben i antologien Probleme einer materialistischen Staatstheorie, sammen med bidrag af Braunmühl, Funken og Hirsch. Suhrkamp 1973. Findes oversat i serien Politiske Arbejdstekster. 
gen privat konsumtion) og at merværdiraten (m') er ens i de tre sektorer: i SIII er den $159,3 \%$, i SI og SII: $160 \%$.

Forholdet mellem k/v er i SI ved akkumulation: 1/1, i SII: 1/1, og i SIII: 10/19. Tallene her er ganske vilkårlige, men reflekterer nok med rimelighed den empiriske sammensætning i de tre sektorer, hvis SIII dækker byggeriet.

\section{vareprodukt:}

1) SI: $4000 \mathrm{k}+1000 \mathrm{v}+1600 \mathrm{~m}$

SII: $1430 \mathrm{k}+351 \mathrm{v}+562 \mathrm{~m}$

SIII: $500 \mathrm{k}+182 \mathrm{v}+290 \mathrm{~m}$

2) SI: $4000 \mathrm{k}+1000 \mathrm{v}+500 \mathrm{~m}_{\mathrm{k}}+500 \mathrm{~m}_{\mathrm{v}}+600 \mathrm{~m}_{3}$

SII: $1430 \mathrm{k}+351 \mathrm{v}+70 \mathrm{~m}_{\mathrm{k}}+70 \mathrm{~m}_{\mathrm{v}}+372 \mathrm{~m}_{3}$

SIII: $500 \mathrm{k}+183 \mathrm{v}+100 \mathrm{~m}_{\mathrm{k}}+190 \mathrm{~m}_{\mathrm{v}}$

Betegnelsen $» \mathrm{~m}$ « efter et tal med bogstavet $\mathrm{k}$, v eller tallet 3 under betyder, at det er en del af merværdien, der går til henholdsvis akkumulation af kvarer, vvarer og anvendes til akkumulation i SIII.

Akkumulationen sætter sig nu igennem som følger, først gennem udvekslingen mellem SI og SII:

3) SI: 4000k $+500 \mathrm{mk}$ erstattes indenfor sektor I selv. Tilbage er 1000v + $500 \mathrm{~m}_{\mathrm{v}}+600 \mathrm{~m}_{3}$.

SII: $351 \mathrm{v}+70 \mathrm{mv}$ erstattes indenfor SII selv. Tilbage er: $1430 \mathrm{k}+70 \mathrm{~m}_{\mathrm{k}}+$ $372 \mathrm{~m}_{3}$.

4) Mellem SI og SII udveksles nu: $1000 v+500 m_{v}$ i form af k-varer byttes med $1430 k+70 m_{k}$ i form af v-varer.

Tilbage er da:

SI: $600 \mathrm{~m}_{3}$ SII: $372 \mathrm{~m}_{3}$

Denne del af SI' og SII's merværdi er beregnet til reproduktion og akkumulation i SIII:

5) SIII: $500 \mathrm{k}+100 \mathrm{~m}_{\mathrm{k}}=600 \mathrm{k}$ udbyttes med $600 \mathrm{~m}_{\mathrm{k}}$ fra SI.

: $182 \mathrm{v}+190 \mathrm{~m}_{\mathrm{K}}$ udbyttes med $372 \mathrm{~m}_{3}$ fra SII.

SI og SII står da med en række varer fra SIII, som de pr. definition ikke kan anvende; de kan da sælge dem til staten eller billedet kan gengives således - som hos Cogoy - at SIII's reproduktive og akkumulative behov dækkes af staten gennem en ekspropriering af SI' og SII's merprodukt via beskatningen. Den sidste løsning er dog alt for simpel, fordi den overser det monetære perspektiv og dermed hele kreditformen.

Hvilke betingelser kan vi nu på baggrund af dette skema, der jo skildrer en $\varnothing$ konomi i perfekt ligevægt, slutte må gælde for reproduktionen under 
kapitalismen? ${ }^{36}$ Thi tilfældet af ligevægt, hvor der altså hverken hersker overeller underproduktion i nogen af sektorerne er naturligvis helt enestående - et forhold der i kapitalismen sætter sig planløst igennem via gennemsnitsprofitratedannelsen og derfor snarere er et orienteringspunkt for produktivitetsdynamikken, der sætter sig igennem via cyklernes gennemsnit, men som aldrig behøver at afspejle en statisk tilstand for systemet.

Betingelserne for ligevægt er de samme her som vi påpegede for identiteten værdi-pris: det er en form for nødvendighed, der aldrig kommer til udtryk i en direkte statisk tilstand, men kun indirekte i grænserne for vækst; det er næsten som med tyngdeloven og linedanseren: hans balanceevne viser sig $\mathrm{i}$ at han ikke falder ned.

Udbuddet i en branche (en sektor består af en klynge af brancher) er bestemt af følgende faktorer: Ved konstant efterspørgsel er udbuddet afhængigt af: markedsværdiniveauet, virksomhedsantallet på de forskellige produktivitetsniveauer, produktivitetsforskellene og dermed forskellene i ekstramerværdi og ekstraprofit, de stoflige muligheder for produktivitetsudvidelse, altså af priserne på fast og cirkulerende kapital.

Afgørende for efterspørgslen ved konstant udbud er udbuddets markedsværdi og mulighederne for akkumulation og privat konsumtion (anvendelsen af merværdi eller dele af den som revenu). Hvis der f.eks., i SI er tale om et markedsværdiniveau, der svarer til det i SII, og der så udvikles de stoflige betingelser for akkumulation m.h. på produktivitetsudvidelse på baggrund af disse høje markedsværdier, så vil akkumulationstakten stige i SI, men således, at produktmassen ikke samtidigt forøges, thi ellers ville markedsværdiniveauet falde, hvilket ingen i sektoren er interesserede i. (Det fremkaldes derimod af konstant udbud, men faldende efterspørgsel).

Hvis akkumulationen har form af en udvidelse af den teknisk/ organiske sammensætning, så vil der indenfor SI blive større behov for k-varer (egne varer) end der skabes, dvs. at de k-varer, der muliggør en udvidet reproduktion i SII må indskrænkes. ${ }^{37}$ Således vil det omvendt være muligt at forøge den teknisk/organiske sammensætning indenfor SI (akkumulation) ved at forøge produktmasse uden at markedsvaerdierne falder, fordi SII's reproduktion og akkumulation - fremtvunget af gennemsnitsprofitraten der gør en udligning mellem ekstraprofitterne i SI og SII nødvendig - kræver en given masse SI-varer og fordi den stigende efterspørgsel på egne varer indenfor SI forøger efterspørgslen.

36. Både Mandel og Hickel har klart fremhævet det forhold at reproduktionsskemaerne i egenskab af ligevægtsmodel ikke kan anvendes til direkte konklusioner om kapitalismens faktiske forløb. E. Mandel: Das Spätkapitalismus, Suhrkamp 1973, kapitel 1. Hickel: Zur Interpretation der marxschen Reproduktionsschemata, trykt i Mehrwert nr. 2. Se også: J. F. Becker: Samhällelig obalans och Marx' system, trykt i Marx och den moderna nationalekonomi, red. af D. Horowitz, Stockholm 1970.

37. Das Kapital, bd. II. s. 491-496. 
Sker der samtidig en akkumulation indenfor både SI og SII, så vil markedsværdiniveauet i SI afhænge af den teknisk/organiske sammensætning i SI og SII og af den form hvorunder akkumulationen konkret foregår. Sker den gennem udvidelse af V(arbejderantal) så vil efterspørgslen ramme SII og have indflydelse på markedsværdiniveauet her: det vil stige og dermed bremse akkumulationen af $\mathrm{v}$ og muligvis tvinge den over i en akkumulation af $\mathrm{k}$-varer. (Og vice versa).

Sagen er, at en underproduktion i SI eller SII kommer til udtryk gennem stigende markedsværdier og dermed gennem et lavere minimumsniveau for kapitalanlæg. Følgelig vil der strømme kapital til denne sektor og udbuddet vil stige på baggrund af loven om dannelsen af gennemsnitsprofitraten. Men en overproduktion vil komme til udtryk i faldende markedsværdier, hvilket igen vil kunne vende billedet, fordi produktionen indskrænkes eller fordi en ny akkumulation af fix kapital for altid forrykker markedsværdiniveauet nedad.

Statens rolle er meget væsentlig her, fordi den gennem investeringsst $\varnothing t t e$ og kreditoverførsler kan gøre akkumulationen i SII f.eks. mulig næsten i takt med en kraftig akkumulation i SI, således at der ikke gennem en underproduktin i SII sættes grænser for udviklingen af produktiviteten og dermed i særlig grad for konkurrencen med udlandet.

Staten står i en dobbeltrolle her, fordi støtten til udbuddet også er en støtte til efterspørgslen, og fordi hele reproduktionsskemaproblematikken - når den skal anvendes til konkrete analyser - må udvides m.h. på verdensmarkedet: større efterspørgsel efter SII-varer betyder konkret: større import af forbrugsgoder. Her kan staten ikke gribe særlig effektiv ind, fordi den ikke kan styre et forbrug der rent faktisk er muliggjort, dvs. at den - som vi skal se - er tvunget til at gribe generelt ind overfor hele efterspørgselsprismet, og dermed under samme hat både produktiv og privat konsumtion.

For udbuddets og efterspørgslens nærmere karakter er mange faktorer afg $\varnothing$ rende hvad angår de mindre betydelige bevægelser: Stigende eller faldende råvarepriser, ændringer i forbrugermønstre, afbetalingsordninger i forbindelse med kreditlofter, sæsonbestemt efterspørgsel, men de afgørende faktorer er og bliver udviklingen i fix kapital og udviklingen i arbejderklassens styrkeforhold.

Mandel skelner ${ }^{38}$ mellem tre typer maskiner hvis udvikling radikalt har ændret kapitalismens teknologiske basis: bevægelse-, transmissions- og arbejdsmaskiner. Især udviklingen i bevægelsesmaskinerne: fra damp- via diesel- til elektro- og elektronik og disse energimaskiners maskinelle fremstilling har ifølge Mandel karakteriseret kapitalismens konjunkturbevægelser i store træk.

Arbejderklassens styrkeforhold er en meget kompleks størrelse, der ikke kan afgrænses rent » $\varnothing$ konomisk «, men også kræver et organisationspolitisk perspektiv.

38. Mandel, ibd. s. 109-113. 
Af alt dette følger, at den simple og udvidede reproduktion under kapitalismen er bestemt af værdiproduktionen: det kommer til udtryk i loven for gennemsnitsprofitratens dannelse og det udtrykker, at producenten er gjort magtesløs overfor sin egen produktion: indførelsen af ny teknik er helt afhængig af profitniveauet, og arbejderklassens rolle i produktionsprocessen er ligefuldt underkastet valoriseringens lov.

Værdien som »processerende værdi« - som Marx så ofte siger i Grundrisse - er kapitalismens væsen, men dette væsen eksisterer kun i sin fremtrædelse, og den er loven for dannelsen af gennemsnitsprofitraten, altså konkurrencens begreb. Skal reproduktionsskemaerne, ja hele analysen på niveauet-for-kapital-i-almenhed have forklaringsevne overfor senkapitalismens fænomener, skal denne fremstillings resultat: indsigten i kapitalrelationen, drages ind gennem konkurrencen. En streng »niveaupietisme « som vi f.eks. ser den hos Yaffe $^{39}$ gavner ikke klassekampens sag, for kun integration af niveauerne - på baggrund af indsigten i deres forskellige forklaringskraft naturligvis - kan give arbejderklassen det analytiske værktøj i hænde, der gør en rigtig strategi mulig.

Det er f.eks. klart af sammentænkningen af reproduktionsskemaerne med ${ }^{40}$ konkurrencens begreb, at man kan se, at en akkumulation i SI der ikke er fulgt op af en akkumulation i SII kan bremses i sit akkumulationstempo af SII's slendrende fart, hvilket kan føre til en intensivering af arbejdet i SI og til en forværring af konkurrencebetingelserne på verdensmarkedet, hvilket igen virker tilbage på arbejderklassens vilkår: fordi det manglende fald i markedsværdierne, der skulle være indtruffet analogt med akkumulationen og altså produktivitetsudvidelsen i SI, fører til forskellige fors $\emptyset \mathrm{g}$ på at begrænse omkostningspriserne ad anden vej, og denne vej er som regel fastfrysning af $1 \varnothing n-$ ninger, arbejdsintensiveringer, etc.

På dennne baggrund er det også helt tydeligt, at en opstilling af en model for den kapitalistiske totalreproduktion, der ikke indeholder en monetær synsvinkel, vil være relativ værdiløs hvis den skal anvendes til at belyse udviklingen i kapitalismen med, eller vise statsinterventionismens grænser. ${ }^{41}$

Marx understreger nemlig, at stofskiftet mellem SI og SII kræver, at der fremskydes en vis sum penge til at realisere vareproduktet og danne udgangspunkt for transaktionen. Men denne pengemasse kan ifølge Marx kun være tidligere forsølvet merværdi, altså enten være akkumulationsfondens eller revenuens pengeform eller være fremskudt gennem handel med guld-

39. D. S. Yaffe: Værdi og pris i Marx’ kapital, trykt i Kritik af den neoricardianske marxisme, Modtryk 1975.

40. Das Kapital, bd. II, s. 505 ff og s. 508.

41. Cogoy, ibd. 
varesektoren. ${ }^{42} \mathrm{Nu}$ er det blot tydeligt, at skulle staten tage penge fra SI, SII og SIII med henblik på at anvende disse til at købe SIII's vareprodukt, så ville det indebære et højere akkumulationstempo i SI og SII (og/ eller en gevaldig intensivering af arbejdet) for at merværdien også skulle kunne dække hele SIII's produktværdi ( $\mathrm{k}+\mathrm{v}+\mathrm{den}$ i SIII skabte merværdi, der ifølge vores skema akkumuleredes rub og stub).

Det er betingelsen for ligevægtig reproduktion og akkumulation i forholdet mellem de to sektorer (SI og SII), at der ikke opstår nogen overskydende kapital i form af varer eller penge, thi det er identisk med overproduktion i en af sektorerne eller underproduktion i en anden.

Skal SII f.eks. betale $n$ varer i skat, så er det udtryk for at en given varemasse ikke kan anvendes til køb af varer i SI - dvs. at akkumulationen bremses i SI eller ikke udvides $\mathrm{i}$ et givet - måske af konkurrencen på verdensmarkedet kræver - tempo. Tænkes skatten monetært - og det er jo netop skattens særlige historiske rolle under kapitalismen at blive opkrævet i pengeform og dermed være en af de faktorer, der fremtvinger den kapitalistiske udvikling ved at omdanne naturalieøkonomi til pengeøkonomi - så er det indlysende, at opkrævning af skat i pengeform ikke blot kræver en ophobning af en given varemasse, der tidligere anvendtes til akkumulation, men også, at denne varemasse må have været fors $\emptyset$ lvet for at kunne fungere som skat, at den altså må foreligge i pengeform.

Hvis forvandlingen fra vareform til pengeform da tænkes foregået mellem SI og SII, så kan den kun betyde bremsning af akkumulationen ved at betyde et manglende genk $\varnothing \mathrm{b}$ i en af sektorerne eller et stop i en given fælles akkumulationsrate. Skal den være opnået gennem en vareudveksling med SIII, så betyder det naturligvis, at bremsningen også kan ramme SIII, at akkumulationen altså også stopper dér, eller endog reproduktionen alt efter skattens størrelse.

Rammer skatten lige hårdt $\mathrm{i}$ alle sektorer - hvilket empirisk set er et delikat spørgsmål, da skattesystemet m.h. på beskatning af kapital er meget indviklet og skattens størrelse afhængig af den enkelte kapitalists evne til at udnytte skattelovens fordele, men forudsætter vi at alle kapitalgrupper er lige gode til det og har lige stoflige muligheder for det, så kan vi antage en ensartet skatteprocent på kapitalerne i alle sektorer - så kræver det en stærkere akkumulation i SI og SII end det ellers ville være påkrævet, alt afhængigt igen af skattens størrelse, akkumulationsraten i SI og SII, og SIII's størrelse og akkumulationsrate og akkumulationssammensætning.

Men tænkes stofskiftet mellem SI, SII og SIII på baggrund af en monetær skattemodel, så er det indlysende, at problemet overhovedet ikke kan løses uden kredittens begreb. For Cogoys løsning, der går ud på at SIII's kapitals produktive form er eksproprieret af staten, bryder med hele statens legitimationsbasis og eksistensbetingelser: for staten kan ikke overskride cirkulationssfærens formelle

42. Das Kapital bd. II, kap. 17. Fremstillingen er her ufuldendt og har karakter af skitse til en systematisk angrebsvinkel på de omtalte problemer. 
reglement: at man erhverver gennem bytte. Staten er således bittert afhængig af forvandlingen af vareproduktet til pengeform, så meget mere som staten overhovedet ikke ville kunne anvende en skattemasse i form af naturalier.

Staten kan altså ikke tage varer fra SI og SII og give til SIII som basis for dennes produktive kapital, men staten må give SIII penge, således, at SIII kan $k \phi b e$ sine reproduktive varer hos SI og SII.

Skærer vi den historiske dimension ud et øjeblik, der ville gøre det hele unødigt vanskeligt, så gælder følgende: SIII's betalingsmidler i forholdet til SI og SII må indgå i totalstofskiftet mellem SI, SII og SIII uden at vaere resultatet af forvandlingen af et vareprodukt til pengeform. SIII må altså enten have modtaget pengene i egenskab af RK (rentekapital), i egenskab af forudbetaling, eller forholdet mellem SIII på den ene side og SI og SII på den anden må tænkes ud fra den komercielle kredit. (To kapitalister fremskyder et vareprodukt til hinanden uden mellemkomst af penge).

Virkningen af dette forhold er entydigt det jeg beskrev i del I, og som jeg igen har understreget i denne del: at efterspørgslen på SI - og SII-varer overstiger udbuddet og at markedsværdiniveauet derfor kan stige eller holde sig stabilt trods akkumulation.

Marx’ gentagne spørgsmål i kapitel 17 af bd II af Das Kapital: hvorfra kommer pengene til at forsølve (forvandle fra vareform til pengeform) merproduktet? synes at have relevans her. Forestiller man sig at de kommer fra tidligere forsølvet merværdi, så ligger der heri en absurditet, idet der aldrig i samfundet kan realiseres større merværdimasse end produktværdien af det tidligere omslag muliggør. En forsølving af en større meværdimasse kan altså kun ske, hvis omkostningsprisen bliver mindre fra omslag til omslag.

Systematisk kan dette problem heller ikke løses gennem inddragelsen af guldvaresektoren, for det indebærer, at guldvaresektorens merværdiproduktion skulle være identisk med totalmerværdien i det $\emptyset$ vrige samfund, en antagelse Marx selv afviser som absurd s. 487 i bd. II af Das Kapital.

Ejheller kan problemet løses gennem den antagelse, at visse kapitaler på et givet tidspunkt ikke akkumulerer, men henlægger deres akkumulationsmateriale $\mathrm{i}$ fonds, der så figurerer som kapitalens produktive form for andre akkumulerede kapitaler, thi dette forøger jo ikke totalpengemassen i forhold til totalmerværdimassen. ${ }^{43}$

Den eneste måde problemet om forvandingen af et større merprodukt i vareform til pengeform kan løses systematisk på er gennem inddragelsen af staten som henholdsvis fremskyder af cirkulationsmidler i form af penge og i form af kapital. Der er altså her tale om statens udstedelse af pengesedler og dens regulering af rentekapitalens omfang i de private banker, og af dens fastsættese af valutabestemmelser, altså først og fremmest af omfanget af kreditten opnåelig i udlandet.

43. Das Kapital, s. 337 og s. 345 ff. 


\title{
4.4. Konsumtionens rolle i totalreproduktionsprocessen
}

\author{
Når Marx s. 500-501 i bd. III af Das Kapital siger:
}

»Lad os forestille os, at hele samfundet kun bestod af industrielle kapitalister og lønarbejdere. Lad os videre se bort fra de prisbevægelser, der forhindrer store dele af totalkapitalen i at reproduceres ved gennemsnitsforhold, og som, på baggrund af hele reproduktionsprocessens almene sammenhæng, således som kreditten i særlig grad udvikler den, altid må frembringe midlertidige almene blokeringer. Lad os også se bort fra de skinforretninger og spekulative omsætninger, som kreditvæsenet befordrer. I så tilfælde ville en krise kun kunne forklares ud fra misforhold mellem produktionen i forskellige brancher og ud fra et misforhold mellem kapitalisternes egen akkumulation og konsumtion. Men som sagerne nu forholder sig, så er erstatningen af de til produktion anvendte kapitaler i vid udstrækning afhængig af de ikke produktive klassers konsumtion, mens arbejdernes konsumtionsevne derimod dels er begrænset gennem arbejdslønnens lovmæsigheder, dels gennem det forhold, at de (arbejderne) kun bliver anvendt sålænge de kan anvendes med profit af kapitalistklassen. Den yderste årsag til alle virkelige kriser forbliver derfor massernes fattigdom og konsumtionsbegrænsning i forhold til den kapitalistiske produktions drift mod en udvikling af produktivkræfterne, der kun finder sin grænse i samfundets absolutte komsumtionsformåen.« Og når han videre i en fodnote

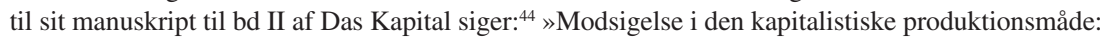
Arbejderne i egenskab af købere er vigtige for markedet. Men som sælgere af deres vare - arbejdskraften - har det kapitalistiske samfund tendens til at begrænse den til minimumspis. - Yderligere modsigelse: De epoker, hvori den kapitalistiske produktion anstrenger alle sine potenser, viser sig regelmæssigt at være epoker med overproduktion, fordi produktionsmulighederne aldrig kan anvendes i et sådan omfang, at der derigennem ikke kun produceres mere værdi, men også realiseres mere; salget af varerne, realiseringen af varekapitalen, altså også af merværdien, er derimod begrænset, ikke gennem samfundets absolutte konsumtive behov, men gennem de konsumtive behov hos et samfund, hvori hovedparten til stadighed er fattige og må forblive fattige...«

- når Marx altså siger således - så er det langt snarere end at være et impulsivt underkonsumtionsteoretisk dogme den antagelse, at bevægelserne i efterspørgslen i det kapitalistiske samfund ikke bestemmes af udsving i arbejderklassens konsumtion indenfor en given lønramme, men derimod, bestemmes af forholdet mellem merværdi og arbejdsløn, eller af totalarbejdslønnen og totalmerværdien.

Heri ligger klart den indsigt som også Keynes formulerer, og som går ud på, at opsparingen i et samfund og behovet for likvide midler er størrelser, der med mindre de omsættes til industrikapital direkte blokerer for samfundes vækst.

Keynes skelnede ikke mellem IK og HK og havde ikke noget »produktivitetsbegreb « som vi kender det fra Marx, men hans General Theory, der er blevet tolket således, at de personer han skriver om skulle være kapitalister og arbejdere i flæng, angår først og fremmest enkeltkapitalisten og hans opsparing, der i form af spekulation og besiddelse af konti eller private gemmer spækfyldt med kontanter, er ødelæggende for den samfundsmæssige vækst.

Keynes kunne selvfølgelig p.gr. af sine politiske interesser, der også var hans erkendelsesteoretiske, ikke se det Marx her så ifølge de sidste to citater, men

44. Das Kapital, bd. II, s. 318, fodnote 32. Dette og det foregående citat er min overs. OFK. 
han kunne se, at kapitalistklassens jagt efter merværdi udhulede akkumulationen, al den stund besiddelse af store likvide midler ikke behøvede være udtryk for en stigning i kapitalens grænseydelseseffektivitet. Marx' lov for den kapitalistiske akkumulation, der udtrykkes i tesen om profitrates faldende tendens på det konkreteste niveau, indeholder den indsigt, at arbejdslønnen aftager relativt i forhold til fix og cirkulerende konstant kapital, også selvom den stiger absolut.

Marx' tese om den stigende kapitalistiske forarmelse, der ikke holder stik idag, har alligevel en kerne af sandhed: for »forarmelse« betyder: indskrænkelse af antallet af produktive arbejdere i løbet af den kapitalistiske akkumulation relativt til stigningen i maskiner og materiel. Men det betyder også indskrænkelse af mængden af produktive arbejdere i forhold til mængden af uproduktive arbejdere.

Dette forhold giver samme resultat som forarmelsestesen hvad angår gennemsnitsprofitraten: den vil falde, fordi kun de produktive arbejdere skaber merværdi.

Den efterspørgsel som de uproduktive arbejdere skaber realiserer nok merværdi, men den begrænser også merværdimassen på totalplan, fordi uproduktive arbejdere pr. definition er arbejdere, der ikke skaber merværdi, dvs. hvis løn tages af revenuen, og altså direkte medvirker til at sænke gennemsnitsprofitraten, hvad enten den indgår i en kapital som HK eller PK, eller blot indgår som løn til tjenester.

Statens efterspørgsel på uproduktivt arbejde har da allerede her karakter af en politisk motiveret begrænsning af forarmelsen, men dette er selvfølgelig ikke hele sandheden, selvom keynesianismen givetvis af sin fader og af sine faddere et tænkt forebyggende, klassemodsætningsdæmpende.

Lad mig ridse grænsen for den private konsumtion op, altså for merværdiens anvendelse til revenu, og dermed virkningerne af sådanne bevægelser på totalreproduktionen:

Hvis vi opdeler totalmerværdien i samfundet $\mathrm{i}$ tre poster:

$\mathrm{M}_{\mathrm{a}}$ : merværdi til akkumulation

$\mathrm{M}_{\mathrm{f}}$ : merværdi til privat forbrug

$\mathrm{M}_{\mathrm{o}}$ : merværdi til opsparing, der ikke er investeringer, så er det klart nok, at udvidelsen af opsparingen har begrænsende virkning på $\mathrm{M}_{\mathrm{a}} \circ \mathrm{g}_{\mathrm{f}}$.

Hvilke virkninger en forøgelse af $\mathrm{M}_{\mathrm{f}}$ vil få er derimod bestemt af hvilke varetyper den anbringes i:

Anbringes den i SIII-varer har den givetvis en negativ virkning på akkumulationen, fordi den vil få markedsværdierne på SI-og SII-varer til at stige, fordi efterspørgslen på disse varer vil overgå udbuddet.

Arbejderklassens indtægt er pr. definition ikke kapital for arbejderen, men kan i egenskab af revenu forvandles til kapital under en kapitalists »varetægt«. Men det kan selvfølgelig spille ind på totalreproduktionen, hvis arbejderen sparer op af en given lønmasse, idet det reducerer efterspørgslen på SII-varer. Hvilken effekt opsparingen vil have er aldeles afhængig af dens funktion som kredit gennem bankerne, dvs. hvilken type varer den qua RK omsættes i. 
Men som allerede nævnt er bevægelsen mellem forbrug og opsparing ikke af den store betydning for totalreproduktionen, når det er arbejderklassen der er tale om.

Det moment derimod, der virkelig medfører størrelsesforskydninger mellem $M_{a}$ og $M_{f}$ og $M_{o}$ er bevægelserne i gennemsnitsprofitraten og dernæst forholdet mellem den fungerende kapi talists profit (Unternehmergewinn) og så renten.

Denne indsigt behersker Keynes' hovedværk og går igen i hele den moderne borgerlige politik. Keynes' begreb for opsparing, der bl.a. indeholder forestilling om en tilbøjelighed for besiddelsen af likvide midler er dog temmelig absurd al den stund det er absurd at tænke sig at folk ville ligge inde med penge $\mathrm{i}$ en samfundsmæssig sammenhæng, hvor pengebesiddelse uden forrentning opfattes som direkte tab, og faktiske er det på baggrund af prisstigningerne. Dette betyder at opsparingen og »hoarding « praktisk er det samme, dvs. at opsparing og investering kun kan skilles fra hinanden hvis man tænker sig opsparing som investering i obligationer og spekulative emner, mens »investering « bliver udlån til industriformål. Den moderne politik viser, at denne type opsparing er en hård nød at knække for regeringen, fordi obligationsrenten er vanskelig at påvirke.

Indfører vi sektormodellen i forbindelse med $\mathrm{M}_{\mathrm{a}}, \mathrm{M}_{\mathrm{f}} \mathrm{og} \mathrm{M}_{\mathrm{o}}$, så er det klart at akkumulationsraten i de forskellige sektorer er afgørende for opsparingens rate, dvs. at spekulation og obligationshandel i vid udstrækning - men naturligvis ikke totalt - er omvendt proportionalt med akkumulationen.

En stigning i den private konsumtion vil kunne give overakkumulation i SI eller underakkumulation i SII, fordi markedsniveauet vil stabiliseres der; men her er vi inde i et problem, hvilket jeg ikke vil gå nøjere ind på her.

Lad os nu gå over til en nøjere udvikling af statsinterventionismens begrænsninger:

\subsection{Totalreproduktion og statsintervention}

På baggrund af Matticks overvejelser i bogen Marx og Keynes angående statsinterventionismens grænser har Cogoy opstillet en tese om hvilke grænser for statsinterventionisme, der følger af kapitalens produktive form:

Gennem indførelse af en tre-sektormodel i stil med den vi lige har fremført, men med udeladelsen af ethvert monetært perspektivt, mener Cogoy at kunne slutte, at »Totalkapitalens akkumulation er ikke mere identisk med summen af den af hver enkeltkapital frembragte merværdi. Totalkapitalens akkumulation er identisk med summen af totalmerværdien minus totalværdien af SIII's produktion. $\ll^{45}$

45. Cogoy, ibd. s. 155. Min overs. OFK. 
Denne konklusion er - som jeg har vist - fuldt berettiget, når SIII's vareproduktion ikke har reproduktiv form.

Men Cogoys videre konklusioner herfra er behæftet med nogle meget typiske fejl: ikke blot således om jeg har påpeget, at hans mangel på et monetært perspektiv og på hele kreditperspektivet gør hans konklusioner meget abstrakte, men således, at hans bestandige opereren på niveauetfor-kapital-i-almenhed gør hans konklusioner uanvendelige på kapitalismens konkrete udviklingsgang.

De ligger tæt op af Matticks opfattelse af forholdet, der lyder som følger:

»Fra et profitsynspunkt betyder overproduktionskrisen således en situation, hvor eksisterende kapital samtidig er for lille og for stor. Den er for stor i forhold til den eksisterende merværdi og den er ikke stor nok til at overvinde manglen på merværdi ${ }^{46}$

Heri ligger spillet på kapitalens enhed af værdi og brugsværdi: værdimæssigt er merværdimassen, der udvindes af den eksisterende kapital, for lille til fortsat reproduktion, det betyder at gennemsnitsprofitraten falder. Samtidigt er det stoflige indhold af merværdien, altså merproduktets produktive form for lille til at gøre den akkumulation mulig, der kan forøge gennemsnitsprofitraten eller i alt fald skabe ekstraprofitter.

Hovedsvagheden ved Cogoys gennemførelse af dette - på lang sigt og på et abstrakt niveau sandsynligvis rigtige - argument er, at det ikke orienterer sig i forhold til gennemsnitsprofitratens dannelseslov. For tager man kreditten med ind, plus et begreb for vækstrateforskellighederne i de tre sektorer, så synes det ikke absolut nødvendigt, at SIII's eksistens skulle medvirke til en begrænsning af værdiproduktionen i samfundet eller til sænkning af akkumulationsraten, der indebærer yderligere hæmmet værdiproduktion.

Vores unders $\varnothing$ gelser i del I af denne artikel viser derimod, at eksistensen af SIII kan betyde en stabilisering af værdiproduktionen ${ }^{47}$ gennem en stabilisering, ja forøgelse af markedsværdiniveauet, fordi efterspørgslen overgår udbuddet over længere tid.

Der er altså gennem konkurrencens begreb givet mulighed for at prisdannelsesmekanismen indeholder evnen til at kompensere for tabet på profit som følge af skatterne.

46. P. Mattick: Marx og Keynes, Blandingsøkonomiens grænser, Røde Hane, København 1973, s. 63.

47. Og af værdirealiseringen, hvis vi ser på den nationale $\varnothing$ konomi som en integreret del af verdensmarkedet. Gennem lån i udlandet skaffes der dækning for den »falske sociale værdi « realiseret i sektor III. Et væsentligt perspektiv angående sammenhængen mellem værdiproduktion og værdirealisering er problemet om hvorvidt den stigende organiske sammensætning betyder en så stærk indskrækning af arbejderklassens beskægtigede del, at købekraften falder i samfundet, dvs. at det producerede ikke kan realiseres. Dette er i sin disproportionale konsekvens et vægtigt argument fra Marx' side mod Ricardos ligevægts-naturalisme, men argumenterne - der udvikles i bd. II af Theorien über den Mehrwert, kap. 17 - er ikke gennemførte. Dette perspektiv er udeladt i denne sammenhæng, da det fordrer et noget andet perspektiv på problematikken. Se i $\emptyset$ vrigt tidsskriftet Mehrwert, nr. 5, kap. 7 og 8. 
Det er altså - som jeg har vist - strengt nødvendigt at focusere på konkurrencen indenfor og mellem brancherne for at kunne afgøre virkningerne af statsinterventionismen.

Heri ligger naturligvis ikke, at dette er et forhold der kan fortsætte over virkelig lang tid: ekstraprofitterne skabes i høj grad ved hjælp af »falsk social værdi «, der dækkes ind gennem import af lånekapital fra udlandet og ad andre veje, men som i længden kræver en udligning, der medfører katastrofale forhold for nationen på verdensmarkedet, hvis den ikke indtræffer.

Men samtidig indebærer det forhold, at den af Mattick og Cogoy fremhævede tendens i kapitalismen, at der i længden vil fremkomme en overproduktion af kapital og en underproduktion af nyværdi, ikke kan give anledning til direkte uformidlede konklusioner angående statsinterventionismens grænser. Thi den nævnte tendens - der jo først fremhævedes af Marx i hele sin konsekvens - er ikke bare bundet til en særlig form for kapitalisme, men hører til kapitalismen som produktionsmåde. Grænserne for statsinterventionisme består nemlig ikke primært i en begrænsning af profitten overalt i samfundet, men derimod i udviklingen af et heterogent og alt for højt prisniveau, samt $\mathrm{i}$ forværringen af landets internationale stilling gennem en beskæftigelsessituation, der er vanskelig at bære for de mindre firmaer i eksportbrancherne, fordi den presser lønningerne i vejret.

Statsinterventionismen bremser langt snarere på hjemmemarkedet akkumulationen og giver anledning til produktivitetsforøgelse gennem intensivering af arbejdet, fordi konkurrencen p.gr. af statens efterspørgselsstabilitet er betydelig reduceret, (produktivitetsforøgelsen sker da ikke gennem anskaffelsen af ny fix kapital). Statsinterventionismen bremser altså delvis profitratens faldende tendens. Mens den altså sikrer profitten på hjemmemarkedet vanskeligg $\varnothing \mathrm{r}$ den situationen for eksportindustrien ved at bremse sænkningen af produktionspriserne her, hvilket medfører at profitraten falder i disse brancher, fordi profitterne på verdensmarkedet er direkte proportionelle med produktivitetsniveau, jo højere produktivitet desto højere profitter.

Statsinterventionismen kan ikke redde kapitalismen, ingen har bedre bevist det end den borgerlige stat selv indenfor de sidste to år. Men inddragelsen af konkurrencens, kredittens og verdensmarkedets begreber viser os, at loven for den kapitalistiske akkumulation som den er formuleret på niveauet-for-kapital-i-almenhed ikke sætter sig uformidlet igennem i statsinterventionismens begrænsninger, men går via dannelse af gennemsnitsprofitraten og produktionspriserne, og her viser det sig at statsinterventionismens grænser ligger $\mathrm{i}$ dens delvise bremsning af akkumulationen, i dens skabelse af en modsætning mellem nation og verdensmarkedet gennem en passificering af konkurrencen i hjemmeindustrien, og dermed frem for alt, i dens blokering af dannelsen af en gennemsnitsprofitrate i samfundet. 


\section{Kapitel 5:}

\section{Konsekvenserne af statsinterventionismen}

Statsinterventionismens årsager skal søges i forholdet mellem det kapitalistiske samfunds $\varnothing$ konomiske basis og så dets politiske overbygning: De modsætninger, der konstituerer basis og som angår besiddelse og ikkebesiddelse af ejendom er det statens opgave at bevare i en konfliktløs form.

Men i selve de ejendomstrukturer, der afgrænser kapitalismen, ligger rammer for interaktion, der netop kommer tydeligst til udtryk i forholdet mellem kapitalist og arbejder. Engang sat bliver ejendomsforholdene i kapitalrelationen til et selvstændigt væsen med sit eget liv, sine egne love og sin egen indre logik. Denne logik indgår i vores samfunds- og tilværelseserfaring gennem vor daglige aktion indenfor kapitalrelationens rammer. Således avler kapitalen sine egne illusioner i sine mere eller mindre villige aktørers bevidsthed. Disse illusioner, der tydeligst er formuleret i »den trinitariske formel « af Marx, illuderer at kapitalismen er et retfærdigt samfund, et rationelt, funktionalistisk samfund, hvor mennesket og teknik og videnskab udvikles bedst, eller i alt fald bedre end andre steder. Staten bliver da en enhed med en $\varnothing$ konomiske basis i revenukildebegrebet: revenukildernes eksistens, og revenuens sikring, omfang og kontinuitet smelter sammen med statens funktion. Den kapitalistiske stat er eksistensen af de tre revenukilder. Alligevel må staten på mange punkter bryde denne sin passive eksistens og manifestere en anderledes, særskilt side af sig selv, for den politiske form, hvori kapitalismen efterhånden overvintrer i den vestlige verden: parlamentarismen, er ikke ganske funktionalistisk indrettet m.h. på kapitalismens bevarelse. Naturligvis er parlamentarismen også vokset sammen med revenukildebegrebet, der danner dets erfaringsmæssige basis, men der ligger i parlamentarismen qua syntesen af revenukildeviljer ikke den konkrete form, hvorunder enheden eller modsætningen i disse viljer effektueres.

Hvor den fascistiske stat på punkter passer meget bedre til virkeliggørelsen af kapitalismens behov i egenskab af produktionsform, så blokerer parlamentarismen ofte for virkeliggørelsen af totalkapitalens behov.

Hvor det, at staten MÅ udspaltes i en række instanser, må blive en udfarende kraft, principielt følger af modsætningerne mellem revenukilderne, så følger formen hvorunder staten farer ud ikke af revenukildernes væsen.

Keynes' værk f.eks. tjener glimrende som illustration til det forhold, at revenukildeejerkonflikterne ikke måtte træde åbenlyst frem i samfundet: Keynes anbefalede hellere prisstigninger end løntrykning af politiske årsager - men kun hvis vi udvikler et differentieret begreb for revenukilderne kan vi udlede de mål og midler hvormed Keynes mente staten burde træde ind på arenaen. 
Denne differentiering består i fremdragelsen af kapitalformerne på niveauetfor-kapitalen-i-dens-realitet: industrikapital, handelskapital, pengekapital, rentekapital, altså i en fremdragelse af konkurrencens niveau og af totalreproduktionsperspektivet og af de kapitalfraktioner, der konstituerer totalkapitalbegrebet, og i en focusering af verdensmarkedets problematik. Nøglen til forståelsen af hvordan statens essens bliver til eksistens er altså at se hvilke former kapitalen på sit konkreteste niveau udspalter sig i, og derudfra - på baggrund af begrebet »materiel interesse«, der angiver den aktions - og erkendelseradius som findes hos individer bundet til deres ejendomsbesiddelse - lokalisere handlingshorisonten for de personer, der tager statens eksistens på sig.

Keynes f.eks. kan lokaliseres i modsætningen mellem industrikapitalister og rentekapitalister, hvor han uden at ændre samfundets struktur ville gribe ind til fordel for de første. Statens identitet som spændingsfeltet mellem en række særinteresser gør, at alle konkrete løsninger må forholde sig til totaliteten, dvs. Keynes kunne ikke bare afskaffe rentekapitalen, men måtte begrænse rentekapitalen under den forudsætning at hans løsning skulle kunne accepteres af alle også - omend blot på parlamentarismens formelle kriterier - af rentekapitalen selv. Skal vi indenfor de sidste år se hvilken grundforestilling, der bliver udslagsgivende for statens aktion, så er det vel nok nationen set i forhold til verdensmarkedet, dvs. ophøjelsen af industrikapitalen til »nationalkapital«. Men derom senere.

Problemet om statens muligheder som aktør overfor sin eksistensbasis men naturligvis kun indenfor rammerne af denne - er givet som problemet om forholdet mellem erkendelse, midler og muligheder: for det første grænserne for den indsigt den borgerlige politiker eller embedsmand har ifølge sine erkendelsesinteresser i deres spejling af den måde kapitalens objektive love fremtræder på i en given historisk konstellation, midlerne han har til rådighed på baggrund af systemets integritet og endelig hans handlingsmuligheder $\mathrm{i}$ forhold til sine politiske meningsfæller og modstandere. ${ }^{48}$

Her adskiller statsinterventionismen sig fra tidligere og seneste politik, ved at reproducere kapitalens illusioner på en ganske særlig måde i ord og gerning.

I det følgende skal statsinterventionismens konsekvenser og grænser opridses ud fra udarbejdelsen af den objektive indsigt i disse grænser i det foregående.

Dernæst skal det borgerlige samfunds egen opfattelse og reaktion mod statsinterventionismen på visse punkter udvikles. Men her tilsigtes ingen komplet fremstilling af statsinterventionismen og dens modtræk, bl.a. focuseres indkomstpolitikken kun i ringe grad, etc. derimod søger jeg mod det perspektiv, der belyser, hvordan staten i sine forskellige aktionsformer forestiller sig det kapitalistiske samfunds funktionsmåde, dvs. hvordan staten forholder sig

48. Erik Ib Schmidt: Dansk Økonomisk Politik, Fremad, 1974, Indledningen. 
til konkurrencens begreb og kapitalformerne. Altså: hvor går grænserne for rationaliteten i den borgerlige stats aktioner?

At tale om positive og negative konsekvenser af statsinterventionismen kan være rimeligt, men en sådan opdeling af konsekvenserne skal ikke foretages her, da de positive og negative momenter er integreret i hinanden. Indledningsvis skal det dog pointeres, at den positive hovedkonsekvens af statsinterventionismen er stabiliseringen af den kapitalistiske basis gennem en stabilisering af de politiske modsætninger henimod et stade, hvor deres eksistensformer lader samfundets evne til at fungere som en enhed bestå: udviklingen af et socialt sikkerhedsnet og underst $\varnothing t t e l s e n$ af gennemsnitsprofitraten er her de væsentligste resultater.

\subsection{Statsinterventionens bestemmelse}

\section{1.a. Markedsvardiniveauet}

På baggrund af 3-sektormodellen udviklet fra konkurrencens begreb og gennem inddragelsen af kreditten skal følgende konsekvenser af statsligt organiseret efterspørsel for en national $\varnothing$ konomi påpeges: Staten skaber en efterspørgsel til SIII ved hjælp af en værdimasse, der kan være skaffet gennem skatter og afgifter, gennem salg af værdipapirer, udstedelse af obligationer, tvungen opsparing, renter af anlægskapital, overskud af statsvirksomheder eller gennem låntagning på det internationale lånemarked og udvidelse af likviditeten ved hjælp af træk på nationalbanken (pengeudstedelse og ophævelse af låneloftet). Denne forøgede værdimasse som staten skaffer til veje $\mathrm{g} ø \mathrm{r}$, at det bliver muligt at realisere en langt større vardimasse end der faktisk skabes indenfor sektorerne.

Dette realiseringspotentiel gør det muligt at markedsværdiniveauet holdes kunstigt oppe gennem statens efterspørgselspres, således at der i visse brancher - nemlig hjemmemarkedsbrancherne især - realiseres enorme ekstraprofitter, fordi markedsprisniveauet justeres efter de mindste og mindst produktive virksomheder.

Skabelsen af denne store masse »falsk social værdi« presser prisniveauet hos nationen op og invaliderer dens muligheder på det internationale marked:

Eksistensen af visse SI- og SII-brancher, der bliver statens »hofleverandører « til et særligt favorabelt pris- og dermed profitniveau, medfører, at gennemsnitsprofitraten ikke udlignes i samfundet, fordi eksportindustrien simpelthen ikke kan realisere sine produkter til så høje produktionspriser. Konsekvensen af statsinterventionismen viser sig da først og fremmest $i$ en forværring af betalings- og handelsbalancen, $i$ en opskruning af omkostningsprisen og i et fald i profitniveauet i eksportbrancherne i sammenhæng med en svækkelse af valutaens position.

Det stigende prisniveau i samfundet fordyrer naturligvis også importen og udløser politiske uroligheder ved at undergrave reallønnen samtidig 
med et stærkt pres fra eksportindustrien om ikke at forhøje den nominelle $1 \varnothing n$.

Staten presses altså ind i et dilemma, om den skal forhøje sin efterspørgsel proportionalt med importens stigende værdi, eller om den skal gribe til politiske løsninger for at få lagt et lønloft, da en af hjemmemarkedets hovedsektorer jo vitterligt er SII, og da det høje prisniveau her trækker priserne på de importerede SII-varer op.

For den statslige efterspørgsel har foruden at skabe et højt prisniveau i hjemmemarkedets SI og SII også gennem stabiliseringen af dette prisniveau opretholdt eksistensen af en række lavproduktive og arbejdsintensive virksomheder i brancherne. Denne tendens er blevet accentueret af den $\emptyset$ gede kreditmasse, således at en række industrikapitaler og handelskapitaler er blevet reddet fra falitten gennem en udstrakt og ofte tabgivende kreditgivning gennem en ukritisk forøgelse af såvel anlægs- som driftskreditter. Således har statens altså gennem sine »anti-rationaliserende « virkninger (konkurrencebegrænsende) medvirket til en forøgelse af beskæftigelsen, der har stillet arbejderklassen stærkt i forhandlingssituationer og dermed forhindret det løntryk som produktionsprisniveauet i industrien delvis kræver. Det stigende produktionsprisniveau er på hjemmemarkedet med dets stigende virkning på importen af alle varetyper gør også reproduktionen af fix kapital vanskelig, ved bestandig at forringe værdien af akkumulationsfonden og ved at overhale afskrivningsprocenten. Det stigende produktionsprisniveau vil altså blive presset yderligere i vejret af stigningerne i værdien af den fixe kapital. ${ }^{49}$

Det er tydeligt at statsinterventionismen generelt må siges at have negative virkninger, fordi den forringer landets rolle på verdensmarkedet og dermed fjerner grundlaget under sine egne eksistensbetingelser: stabiliseringen af den politiske overbygning. For stabiliseringen udhules når staten ikke længere kan forsyne arbejderklassen med den fornødne »materielle« kompensation for undertrykkelsen.

Også forøgelsen af skattebyrden på arbejderklassen som følge af statsinterventionismens financeringsbehov medvirker til at bringe den stiltiende socialkontrakt i fare. Om skatterne på arbejderklassen skal opfattes som taget fra den variable kapital, altså som en reduktion i arbejdernes revenu, eller om den skal opfattes som en forøgelse af den variable kapital og dermed som en forringelse af merværdiraten er et def initorisk problem, der kræver en bestemmelse af reallønnen for at kunne løses. På niveauetfor-kapitalen-i-dens-realitet viser det sig, at en forøgelse af skatteprocenten vil medføre en forøgelse af produktionspriserne ved at forøge omkostningsprisen og dermed sætte det markedsværdiniveau i vejret på baggrund af hvilket en given ekstraprofit kan realiseres, hvis vi tænker os reallønnen som konstant. Ved faldende realløn kan en forøgelse af personbeskatningen godt forløbe med konstante produkti-

49. Både Altvater og Dombrowsky fremhæver dette forhold. Se artiklerne i Prokla nr. 17/18. 
onspriser, men der kræves givetvis politiske indgreb for at en sådan situation kan opretholdes, hvilket for øvrigt også hører med til billedet af statsinterventionismen, hvis vi tager lande som USA, Holland, England og også - omend i mindre grad - Danmark. Om stigende personbeskatning ved konstant realløn er identisk med det, der på niveauet-for-kapitalen-i-almenhed hedder et fald $\mathrm{i}$ merværdiraten, på kortere sigt, er afhængig af den virkning på den statslige efterspørgsel som de stigende produktionspriser medfører, og af akkumulationstempoet og akkumulationssammensætningen.

\section{1.b. Akkumulationsimperativet}

Som allerede nævnt vil statsinterventionismen over kort tid kunne modificere tesen om profitratens faldende tendens ved at opretholde en efterspørgsel, der bremser det akkumulationsimperativ, der er indbygget i den kapitalistiske samfundsform. Gennem et heterogent gennemsnitsprofitniveau til fordel for hjemmemarkedsbrancherne vil store ekstraprofitter og eksistensen af en række lavproduktive foretagender kunne opretholdes. Statsinterventionismen er altså egentlig i modsætning til konkurrencens begreb, fordi den sænker produktivitetsniveauet og forhaler den generelle indførelse af højere produktivitetsgrænser, (minimumsgrænser).

Forudsætningen for profitratens faldende tendens er jo - hvilket man ofte glemmer fordi man tænker profitratefaldet på niveauet-for-kapital-i-almenhed p.gr. af denne teses lighed med akkumulationstesen i bd. I af Das Kapital - dannelsen af en gennemsnitsprofitrate i hele samfundet, dvs. en udglatning af forskellene i ekstraprofitter brancherne imellem. Men statsinterventionismen forhaler dette.

Den forhaler også konkurrencen mellem arbejderklasse og kapitalistklasse ved at udvikle et socialsikkerhedsnet for arbejderklassen såvel som et sikkerhedsnet for profitten.

Hvor statsinterventionismen synes afgjort til fordel for visse kapitalgrupper, nemlig for enkeltkapitalerne i hjemmemarkedsbrancherne, der leverer varer til SIII, og for SIII selv, så er det tvivlsomt om den er til fordel for de mindre handelskapitalister (grossister og detailhandlere), fordi beskatningen falder hårdt her, og fordi mange af disse virksomheder er for små til at udnytte kreditmulighederne rigtigt.

Om statsinterventionismen har været til fordel for arbejderklassen er et vanskeligt spørgsmål, men givet er det at bremsningen af akkumulationen til fordel for intensiveringen af arbejdet, som eksistensen af mange små virksomheder indebærer, ikke har været til fordel for de enkelte arbejdere.

Endelig har statsinterventionismen skabt en gruppe af ansatte i SIII, hvis eksistens direkte er båret materielt af interventionen, og disse gruppers interesser er selvfølgelig positivt forbundet med statens aktivitet.

Selvom statsinterventionen nok har forøget totalmerværdimassen i forhold til hvad en ren konkurrencekapitalisme ville have præsteret ved samme tekniske niveau, så er det betvivleligt, om interventionen har været til fordel for kapitalismen: for hvor den ujævne udvikling af produktiviteten indenfor brancherne, 
således, at få store firmaer producerer med stort og udviklet kapitalapparat mens hovedparten producerer med et mindre og dårligt, har givet store ekstraprofitter, så har hele udviklingen medført en internationalisering af kapitalen, der efterhånden gør nationalstaten til en mindre effektiv vogter af kapitalens interesser. Det betyder, at en række nationale kapitaler kommer i klemme p.gr. af for lav produktivitet, hvilket igen virker tilbage på det nationale system som en trussel for stabiliten. Måler vi derimod statsinterventionismen med »planøkonomiske« alen, så er det tydeligt, at dens resultat er et enormt ressourcespild på grund af den »irrationelle« udvikling af produktiviteten indenfor brancherne. Hvor Mattick og Cogoy sikkert har ret i deres konklusioner på længere sigt, så er det dog forkert uden forbehold at konkludere, at SIII's eksistens er identisk med en totalreduktion af merværdien i SI og SII identisk med produktværdien af SIII. Thi først gennem inddragelsen af konkurrencens niveau, altså loven for dannelsen af gennemsnitsprofitraten og produktionspriserne viser det sig hvordan loven for den kapitalistiske akkumulation sætter sig igennem på baggrund af eksistensen af en relativ stærk stat i senkapitalismen.

\subsection{Statens ikke-selektive efterspørgsel og kredit}

Det er karakteristisk for statsinterventionismen, at den i ringe grad søger at styre sine kreditter og sin efterspørgsel i retning af givne kapitalfraktioner, en holdning der netop forkastes af den borgerlige stat selv i dens brud med de tidligere former for statsinterventionisme efter krisen 1974. Staten skelner altså ikke mellem kreditter til industrikapital og til handelskapital før 1974. Indtil 1-1-1974 var låneloftet for finanslån i udlandet 5 millioner kr. for aftaler truffet $6 \mathrm{mdr}$. før eller for kontraktlige forpligtelser gældende $12 \mathrm{mdr}$. frem. De eneste investeringer, der ikke måtte tages lån til var byggeanlæg, financering, leasing og holding, ellers var låntagningen fri.

Statens midler til indgreb i $\varnothing$ konomien var altså begrænset til en generel penge- og finanspolitisk stramning, der helt klart også og måske især ramte eksportindustrien og industrikapitalen $\mathrm{i}$ almindelighed ved at presse renten opad, og til indkomstpolitiske indgreb.

Således ligger der i hele Keynes' pespektiv en manglende forståelse for hvilke typer investeringer, der gavner samfundet som helhed, ja Keynes har faktisk ikke udviklet et totalkapitalbegreb, men er bundet til perspektivet for enkeltkapitalen, der betragter alle investeringer med afkast som »produktive « og renten som fjende nr. 1.

Det er karakteristisk for »multiplikator-effekten « - et begreb, der vel mere end noget andet udtrykker keynesianismens essens - at dette begreb ikke indeholder nogen konkretere forestilling om hvilke typer kapitalanlæg der ville gavne væksten. Her opfattes »indtægtsskabende« investeringer som produktive, m.a.o. en ren reproduktion af den trinitariske formels illusioner. Virkningerne af statsinterventionismen er da også afgørende bestemt af SIII's pro- 
duktions særlige karakter: er der som i Del 1 tale om byggeriet, så vil dele af denne produktion være produkton for arbejderklassen, mens en anden del vil være offentligt byggeri.

Produktionen for arbejderklassen indgår i SII og den statslige efterspørgsel vil her have den virkning, at den stabiliserer markedsværdiniveauet, men det er ikke sikkert at den vil forringe akkumulationsfonden i SI og SII. Det er nemlig klart at statslig efterspørgsel også på reproduktive goder vil have en samfundsmæsig effekt, et forhold er slet ikke kan tænkes i Cogoys fremstilling.

Byggeri for staten i form af administrationsbygninger vil derimod forøge markedsværdierne i SI og SII både ved at forøge efterspørgslen og ved at indskrænke akkumulationsfondens reproduktive form i disse sektorer (som Cogoy altså påpeger).

Disse virkninger er igen afhængige af hvorfra staten får sine indtægter: får den dem fra beskatning af kapitalistklassen, så er der i første tilfælde tale om en omfordeling af efterspørgslen fra visse kapitalgrupper til andre, staten allierer sig da sporadisk med visse enkeltkapitaler, men totalkapitalen påvirkes ikke.

I det andet tilfælde vil både enkeltkapitalgrupper og totalkapitalen forfordeles, hvis efterspørgslen financeres af skattepenge.

Stammer efterspørgslen derimod fra lån i udlandet vil virkningen først følge senere alt afhængig af de former hvorunder låntagningen udlignes. Den umiddelbare virkning vil være bestemt af renteniveauet og betalingsfristen, og af hvilke former for produktion lånerne anvendes til at skabe efterspørgsel på. Er der tale om det første tilfælde her ovenfor vil kreditten ikke have andre virkninger end en forøgelse af markedsværdiniveauet og ekstraprofitterne hos visse kapitaler, fordi der gives mulighed for at realisere mere værdi end der produceres. Renterne vil her fordeles over hele samfundet og udgøre et afbræk i totalmerværdien.

I det andet tilfælde vil det forhold, at efterspørgslen er financeret af et lån i udlandet, blot forstærke den allerede konstaterede virkning.

Virkningen på profitten i samfundet af denne efterspørgsel er altså i sit negative aspekt indirekte: det stigende markedsniveau i hjemmemarkedsindustrien belaster konkurrenceevnen på verdensmarkedet, og svækker låne- og eksportmulighederne og dermed grundlaget for statsinterventionismen. Cirklen er ond.

Heroverfor har staten kun en mulighed: at bremse efterspørgslen. Men for at kunne gøre dette må den gribe aktivt ind i betingelserne for visse revenukilders eksistens, nemlig arbejdskraftens. Staten må altså bryde illusionen om fællesinteresserne, der rummer særinteresser i sig, og det gør den nødigt. Derfor de strålove for profit- og avancestop, der indførtes samtidig med indgrebene mod arbejderklassen i foråret 75 .

Men her er statens aktionsgrundlag allerede ved at forskyde sig fra illusionen om revenukildernes forenelighed over i forestillingen om fællesskabet som en organiseret forretning, hvis identitet skabes i forholdet til udlandet, og hvor revenukilderne optræder som omkostningsfaktorer samtidigt med at de fungerer som krav på indtægt proportionalt med deres størrelse. 


\subsection{Staten og udbuddet}

Statsinterventionen sætter sig ikke alene igennem via skabelse, stabilisering og forøgelse af efterspørgsel, men også gennem en skabelse, stabilisering og forøgelse af $u d b u d$.

Stimuleringen af udbuddet sker direkte gennem investeringer, investeringsstøtte og favorable lånemuligheder, samt gennem en høj afskrivningsprocent.

»Udligningen af værdier til produktionspriser (Kostenpreisen) sker kun derigennem, at den enkelte kapital fungerer som en med sin egen størrelse proportional del af klassens totalkapital, og at klassens totalkapital fordeles over de forskellige specielle brancher i forhold til produktionsbehovene. Dette sker gennem kreditten $\kappa^{50}$

Staten bliver således en nødvendighed for dannelsen af produktivitetsniveauerne i brancherne, fordi den alene - gennem garanti - kan skaffe den kreditmasse som akkumulationen på nationalt og internationalt plan kræver.

Det er derfor et direkte udtryk for statens manglende handlemidler og for dens politiske blokeringer - snarere end for dens manglende indsigt - når den tager pengepolitiske midler i anvendelse til at bremse kreditten, fordi den derved bremser for både industrikapitalens og handelskapitalens akkumulation, hvor kun den sidste af produktivitetshensyn burde bremses, og den første som grundlaget for $\varnothing$ konomisk vækst - burde befordres. Når staten derimod 1-1-1974 begrænser låntagningen i udlandet til anlægsinvesteringer og dermed udelukker lån til driftskapital ${ }^{51}$ så er der tale om en selektiv kreditpolitik og dermed om et brud med den trinitariske formels præmisser: en formel ligestilling af kapitalformerne på totalplan, (se fremme), til fordel for en mere rationel aktion i forhold til de væsenslove, der styrer det kapitalistiske samfund.

Statsinterventionismens relative ikke-selektive kreditpolitik har - dens ofte stramme karakter til trods - haft den virkning, at den har kunnet fremme spekulation uden at staten har kunnet kontrollere det.

Herved uddybes modsætningen mellem industri- og rentekapital. For statens udbudsskabende- og dermed produktionsprissænkende muligheder - er helt afhængige af dens muligheder for at fordele kreditten på de enkelte kapitalfraktioner. Derfor indebærer kreditforøgelsen ikke med nødvendighed nogen stigende produktivitet i samfundet, altså en forbedring af handels- og betalingsbalance, men kan føre til forøgelse af spekulationen, af obligationsudstedelsen m.h. på anskaffelsen af penge til ikkereproduktive formål, driftskreditten og af afbetalingshandlen. Forøgelsen af kreditten gennem en diskontosænkning f.eks. behøver altså ikke føre til stigende udlånsvirksomhed til industrien, etc. Keynesianismens

50. Theorien über den Mehrwert, bd. III, s. 508, min overs. OFK. »Produktionspriser« hedder ofte i Theorien über den Mehrwert »Kostenpreise«.

51. Danmarks nationalbank, beretning og regnskab, 1974, s. 81-82. 
tese om livkiditets- og kreditforøgelse (den blander ofte de to forhold sammen) som et middel til samfundsmæssig vækst er således absolut ikke noget probat middel med mindre andre betingelser er tilstede. (Hvilket Keynes for øvrigt selv var ganske på det rene med, for ham var opsparing og investering jo netop en ideel, ikke en faktisk, identitet.)

\subsection{De subjektive illusioner og statsaktivitetens grad af rationalitet}

Det fremstillede peger henimod det opgør med statsinterventionismens traditionelle former, der indledtes af venstreregeringen på baggrund af krisen.

Pengepolitiske stramninger, indførelsen af mere selektiv kredit, indkomstpolitikken, nulstillingen af pristallet og bygge- og anlægsstoppet, disse forhold viser at det politiske klima giver mulighed for andre aktionsformer. Udviklingen af en ny totalforestilling for statslig aktion: forestillingen om samfundet som en »forretning « hvis interesser i store træk falder sammen med industri - og her især eksportkapitalens, udgør delvis et brud med det fællesskabsbegreb, der følger af den »trinitariske formel«.

De regerende partiers og organisationernes indsigt i nationens afhængighed af verdensmarkedet for opretholdelsen af det kapitalistiske system gør en mere magtpræget statslig politik mulig, hvor der bl.a. spares gennem en reaktion mod politisk mindre magtfulde grupper: uddannelsessøgende, etc. og mod meget brede og derfor også politisk magtesløse grupper såsom »forbrugerne«.

Staten handler her på en anden totalitetsopfattelses grundlag end det tidligere var tilfældet: revenukilderne sideordnes ikke længere på totalplan, men visse aspekter af revenukilden »kapital « fremdrages som afgørende for helhedens beståen: industri- og eksportkapital.

Dermed brydes med keynesianismens identitet mellem indtægtsfor $\varnothing$ gelse og økonomisk vækst. Vækst er kun forenelig med stigninger i visse former for indtægt.

Således kan staten på baggrund af sin nye legitimationsbasis: at revenukildernes opretholdelse og kontinuitet er afhængig af nationens position på verdensmarkedet (understreges naturligvis yderligere af medlemsskabet af EF) gribe ind over for revenukilden »arbejdskraft « og overfor fraktionen »handelskapital« af revenukilden $» k a p i t a l \ll$.

Også overfor ejerne af jord - hvor man dog næppe kan tale om revenukilde i samme grad som Marx gjorde det idet han forudsatte modsætningen mellem jordejere og forpagtere - gennem diskontostigninger, der får rente på obligationer til at stige, kan staten gribe ind.

Endelig er der også tale om indgreb overfor forbrugerne som helhed gennem begrænsningen af forbrugskreditterne.

Statens aktionsformer kan altså ikke længere ganske rummes i begrebet for den trinitariske formel, men må - selvom statens eksistensgrundlag i vis udstrækning stadig er denne »formel«, da kapital og arbejde stadigt fremstil- 
les som formelt ligestillede »produktionsfaktorer «, hvis værdi begrundes i knapheden på dem - konkretiseres med henblik på de fraktioner, der følger af kapitalens formspecificeringer på niveauet-for-kapitalen-i-densrealitet: industrikapital, handelskapital, pengekapital, rentekapital.

Den borgerlige stat kan nu erkende og handle ud fra indsigten i modsætningerne mellem industri- og handelskapital: indførelsen af restriktionen på låntagning i udlandet til andet end anlægskreditter viser dette tydeligt, og også den stiltiende aftale mellem nationalbanken og privatbankerne om at begrænse driftskreditterne.

Derimod står det stadigvæk ikke i statens magt at gribe restriktivt ind overfor rentekapitalen, fordi en udvidelse af kreditten fremmer efterspørgslen også selvom den anlægges i fast kapital, mens et lavt kreditloft forhøjer renten, forhold, der begge har negativ virkning på eksportkapitalens betingelser. Påvirkningen af renten er nemlig uløseligt bundet til obligationsmarkedet således, at en kreditstramning af hensyn til det ekspanderende prisniveau gennem f.eks. nationalbankens salg af obligationer vil medføre en rentestigning p.gr. af den faldende likviditet samtidig med at kursfaldet på obligationer (sammen med den stigende rente) kan få alvorlige politiske konsekvenser fordi store dele af vælgerskaren er parcelhusejere og derfor integreret i obligationsmarkedet.

Samme virkning har en stigning i diskontoen og en stramning af låneloftet: det hæmmer langtidskreditter og dermed anlægsinvesteringerne og således nationens position på verdensmarkedet. Den moderne borgerlige stats problem er på mange måder rentekapitalen som den, jo mere nationen integreres i verdenskapitalismen og kreditten udvikles, bliver mindre og mindre herre over.

Men problemet er, om det borgerlige samfund ud fra sin legitimationsbasis overhovedet kan gribe ind overfor rentekapitalens interesser, fordi rentekapitalen er prototypen på kapital i egenskab af revenukilde: betvivlelsen af rentekapitalens eksistensberettigelse ville være ensbetydende med en åben tilbagekaldelse af kapitalens ret som revenukilde. Thi i rentekapitalen fuldendes konkurrencens facadeillusion i yderste abstrakte potens: kapitalen som abstrakt, ustoflig værdi afkaster værdi proportionalt med sin størrelse.

Rentekapitalen er i det borgerlige univers en »produktiv« størrelse og må være det, fordi kapitalens eksistensgrundlag er »knapheden«: både rente og profit er dybest set begrundet i kapitalens sjældenhed i kombination med dens samfundsn $\varnothing$ dvendighed..$^{52}$

Institutionaliseringen af knaphedsdoktrinen i og med revenukildebegrebet får rentekapitalen til at fremtræde som noget produktivt: I renten »fixeres produktionens resultat som en konstant og derfor forudsat betingelse for denne (produktionsmåden) og endda som konstant egenskab ved de tingslige (sachlichen) produktionsbetingelser $~_{53}$.

52. Om den subjektive værditeoris illusioner, se Mehrwert, nr. 1.

53. Theorien über den Mehrwert, bd. III, min overs., Marx' fremhævelser, OFK. 
At staten for $\varnothing$ jeblikket synes at identificere sig selv med eksportkapitalen og dermed med industrikapitalen betyder ikke at den stiller sig i eksplicit modsætning til rentekapitalen, for det ville være ensbetydende med en fornægtelse af dens eget væsen, men den kan fremstille rentekapitalens fortsatte produktivitet som afhængig af industrikapitalens fremgang. Selv om dette naturligvis ikke gøres ved at rentens logiske afhængighed af gennemsnitsprofitratens absolutte størrelse og den fungerende kapitalists relative mangel på profit ekspliciteres.

Hertil kommer desuden, at rentekapitalen i sig selv heller ikke er nogen enhed, men igen må spaltes op i forskellige interessefraktioner, hvilket eksistensen af rentemarginalen tydeligt viser: der findes både sparere og så dem, der lever af at låne disse opsparede midler ud.

Hvad er nu - må vi til sidst spørge - grænsen for den »nye « type statsindgreb ny i Danmark siden krigen, men ikke i forhold til Holland, England og USA.

Grænserne for statens indsigt i den kapitalistiske verdenssammenhæng, i kapitalismens »rationalitet« (immanente), er både sat af dens aktørers interesser og deres handlingsmuligheder. Interesserne er for hovedparten de abstrakte fællesinteresser i opretholdelsen af kapital og arbejde i deres nuværende form, men handlingsmulighederne er bestemt af konjunkturerne på verdensmarkedet, af det politiske klima og af de midler, som statens legitimationsbasis tillader, altså af meget »generelle« midler.

Ifølge sit væsen som både kapitalisternes $o g$ arbejdernes stat kan staten aldrig handle helt rationelt ud fra det virkelige reproduktivt betemte totalitetsbegreb, men den kan idag - presset til det af statsinterventionismens svagheder - nærme sig en forståelse for et totalitetsbegreb. Det ser således ud: Alt det arbejde, der gavner samfundet skal høre under følgende tre grupper:

I) Arbejde, der skaffer varer eller tjenester til eksport, og som ikke medvirker til en forringelse af handelsbalancen. (Hvor akkumulationsfonden stammer fra spiller ingen rolle).

II) Arbejde, der begrænser det private og offentlige forbrug.

III) Arbejde, der begrænser totalomkostningsprisen.

Bruddet med den mere generelle formel: alt indtægtsskabende arbejde fremmer væksten, er tydelig. Der er blevet plads til en forståelse for at totalkapitalen i forhold til udlandet stilles dårligere, jo mere revenukilderne og revenuerne vokser, fordi de på verdensmarkedet direkte indgår som dele af eksportkapitalens omkostningspris:

V og K = IK's og HK's, PK's og RK's profitter.

Grænserne for statens aktion til kapitalismens stabilisering ligger altså i kapitalen selv: i modsætningen mellem kapital og arbejde og mellem kapitalfraktionerne, de er på engang de samfundsmæssige gruppers indtægtskilder og de faktorer, der konstituerer gennemsnitsprofitraten. 
Det er her gennemsnitsprofitraten, der lader eksportindustriens forfordeling gennem statsinterventionen fremtræde for enkeltkapitalen i eksportindustrien.

Gennemsnitsprofitraten sætter sig her igennem via et krav fra eksportkapital-fraktionen om en bremsning af de faktorer, der hæver omkostningsprisen og sænker profitrateniveauet i disse brancher (eksportkapitalbrancherne) fordi produktionsprisniveauet ligger fast på verdensmarkedet.

Dette krav sætter sig igennem som et generelt krav til statsinterventionismen som helhed, nemlig kravet om offentlige besparelser og om indkomstpolitiske løsninger.

Disse krav er jo også blevet opfyldt efter 1973, hvilket loven om forlængelse af de kollektive overenskomster og aftaler med bygge- og anlægsstoppet viser.

Men her antydes en ny dimension for gennemsnitsprofitratens funktionsmåde: gennemsnitsprofitrten sætter sig ikke nødvendigvis igennem via en overførsel af kapital fra en branche til en anden - således som Marx primært tænkte det - men den sætter sig også igennem via staten: ud fra sin samfundsmæssige nøgleplacering som nationens repræsentant på verdensmarkedet og dermed som et af grundlagene for statsinterventionismens mulighed i det hele taget kan eksportindustrien stille krav til samfundet som helhed, der effektueres af staten gennem begrænsninger i efterspørgslen og gennem politiske løsninger på arbejdsmarkedets konflikter.

Gennemsnitsprofitraten i samfundet dannes altså ved at staten bryder med revenukildebegrebet på visse punkter og direkte opfatter disse kilder som dele af totalomkostningsprisen overfor udlandet.

Den ophævelse af konkurrencens skarpeste former som statsinterventionismen indebar i sin milde form - naturligvis er der ikke tale om en ophævelse af konkurrencens begreb, da dette jo regulerer hele virkningen af statsefterspørgslen gennem markedsværdiniveauet og eksistensen af ekstraprofitter - revideres altså via verdensmarkedet, idet eksportkapitalen kan stille kravet til samfundet som helhed om en sænkning af markedsværdiniveauet på hjemmemarkedet.

Vi ser altså, at statsinterventionismen klart er underkastet konkurrencens begreb og dermed kapitalens begreb, og at grænserne for statsinterventionismen netop ligger i loven for dannelsen af gennemsnitsprofitraten og produktionspriserne, nationalt og i internationalt sammenhæng.

Staten befinder sig altså virkelig i et dilemma: eksportens succes er betingelsen for statsinterventionismens $\varnothing$ konomiske mulighed, samtidigt med at netop eksportindustrien befinder sig i politisk modsætning til så godt som alle andre grupper og klasser i samfundet, selvom det naturligvis kun er på overfladen, da eksportindustrien jo indgår konstituerende som en del af IK og dermed konstituerende i skabelsen af gennemsnitsprofitraten hvoraf de resterende kapitalfraktioner lever. Betingelserne for eksportsucces er altså politisk uro og betingelsen for politisk ro ligger i eksportindustrien... 
Konsekvenserne af statens mere restriktive politik er en forringelse af arbejderklassens realløn og af dens arbejdsvilkår.

Det er en underbygning af profitratens faldende tendens - som den »milde « statsinterventionisme jo kunne skubbe lidt på afstand - gennem en sænkelse af markedsværdiniveauet og dermed en reduktion af en række ekstraprofitter og destruktionen af en række enkeltkapitaler.

Virkningen af den »strenge « intervention er afhængig af konjunkturerne på verdensmarkedet, altså af mulighederne for eksport ved et givet produktivitetsniveau: hvor meget skal industrien akkumulere for at klare sig, etc.?

Her får Matticks teser fuld gyldighed: for tendensen går her i retning af en formindskelse af totalmerværdien relativt til totalkapitalen og dermed vil akkumulationen og statens indtægtsmuligheder bremses.

Samfundet bliver da ekstrafølsomt overfor de mindste udslag i merværdiraten, hvilket forøger presset på arbejderklassen. Stigningen i produktivitet og det relative fald i anlæg af produktive kapitaler som følge af stigningen i minimumsgrænsen for kapitalanlæg på grund af de faldende produktionspriser vil da forøge reservearmeen i form af arbejdsløse og uproduktivt ansatte, hvilket yderligere vil begrænse merværdien - med mindre staten begynder at lukke op for posen - og dermed få modsætningerne mellem kapitalist- og arbejderklasse til at eskalere.

Frederiksberg, 7-12-1975.

Fortscettelse fra side 184

tellektuelles rolle identificeret med at gøre den marxistiske videnskab (i fagkritisk form!) til det formidlende led i »alliancepartnerskabet med arbejderklassen«. At væsentlige skranker herfor ikke blot ligger i »teoriens isolation«, men dels i den kapitalistiske arbejdsdelings historiske konstitution, dels i, at arbejderbevægelsen i dag ikke har udviklet sig samfundsmæssigt som klassebevagelse, synes ikke at bekymre HJN. Endnu mindre lægger han op til en forståelse af, at i det omfang arbejderklassen kan betegnes som det kapitalistiske samfunds revolutionære kraft, må det være begrundet i dens erkendende praksis indenfor det borgerlige samfund, og ikke i dets historisk objektive, (men endnu ikke erkendte) interesse i omvæltningen af de kapitalistiske produktionsforhold.

De marxistiske intellektuelles politiske rolle lades på baggrund heraf i bedste fald udiskuteret, i værste opstilles en i det borgerlige samfund utænkelig situation, (s. 85:) »hvor der ingen principiel forskel er på intellektuelle kommunister og kommunistiske arbejdere.«

Januar 1976 